\title{
WORK RELATIONSHIPS AS INVESTMENTS: THE UNEXPLORED COMPONENT OF CONTINUANCE COMMITMENT
}

\author{
Melissa A. Cohen
}

\begin{abstract}
A Dissertation
Submitted to the Graduate College of Bowling Green

State University in partial fulfillment of the requirements for the degree of
\end{abstract}

\section{DOCTOR OF PHILOSOPHY}

May 2007

Committee:

Steve M. Jex, Advisor

Steven H. Cady

Graduate Faculty Representative

Milton D. Hakel

Anne K. Gordon 


\begin{abstract}
Steve M. Jex, Advisor

Continuance commitment, a form of organizational commitment, has typically been characterized by tangible, financial investments made in a job. This study conceptualized work relationships as investments that may explain additional variance beyond the typical work investments in two outcomes, the personal sacrifice dimension of continuance commitment and intentions to quit. Four work relationship constructs, network relationship quality, network size, relative network status, and network interaction, were measured by asking participants to name and describe individuals from their work social network in five categories: primary supervisor, coworkers, subordinates, friends, and work associates. Results indicate that network size predicts incremental variance in personal sacrifice and network relationship quality predicts incremental variance in intentions to quit. Extraversion, agreeableness, and work locus of control also predicted several work relationship constructs. Future research should attempt to establish causality, replicate these findings, explore new relationship constructs, and identify other outcomes that can be further understood by examining their association with work relationship constructs.
\end{abstract}




\section{ACKNOWLEDGMENTS}

I have many individuals to thank for aiding me in the completion of my dissertation. I would like to thank my advisor, Steve Jex, for all of his insight, guidance, and assistance throughout the dissertation process. He made the process of completing it while working fulltime very smooth and easy. I would also like to thank my other committee members, Milt Hakel, Anne Gordon, and Steve Cady, for their thoughtful comments and ideas that helped make my project a success. I must thank all of the organizations that either explored the possibility of participating in my study or actually participated, as well as the individuals that helped me gain access to these organizations and helped to manage the internal data collection process. Lastly, an important thank you goes out to all of my family and friends who were very supportive and helpful throughout this process. 


\section{TABLE OF CONTENTS}

Page

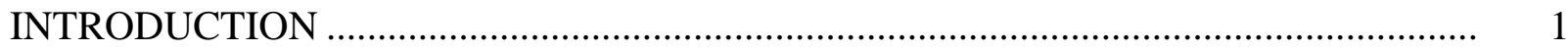

Affective Commitment .....................................................................................

Antecedents of Affective Commitment ................................................ 4

Psychological Processes Involved in Development of Affective

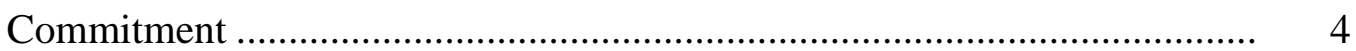

Normative Commitment ............................................................................. 5

Antecedents of Normative Commitment .................................................. 5

Psychological Processes Involved in Development of Normative

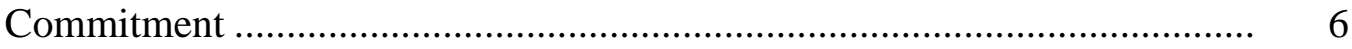

Continuance Commitment .....................................................................

Antecedents of Continuance Commitment ................................................. 7

Psychological Processes Involved in Development of Continuance

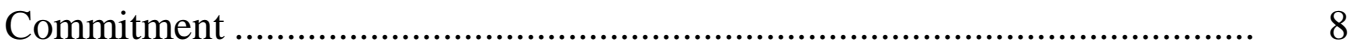

Dimensionality of Continuance Commitment ......................................... 8

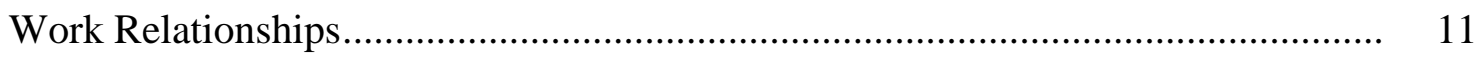

Definition of Work Relationships ....................................................... 11

Relationship Development............................................................... 12

Importance of Studying Work Relationships.......................................... 13

Consequences of Relationship Loss...................................................... 14

Relationship Forms and Exchange Theories.......................................... 16

Beyond Exchange Theories ............................................................... 17 
Existing Research on Work Relationships............................................. 18

Work Relationships and Commitment...................................................... 20

The Investment Model .................................................................................. 23

The Model ......................................................................................... 23

Applications of the Model ...................................................................... 25

Conclusions about Work Relationships and Commitment ................................ 27

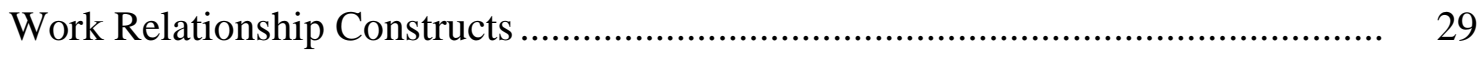

Network Size................................................................................. 29

Relative Network Status ................................................................ $\quad 30$

Network Interaction ................................................................ 30

Network Relationship Quality .......................................................... 31

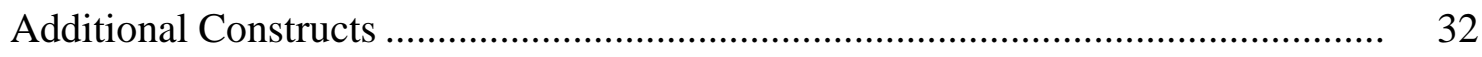

Need for Affiliation............................................................................ 32

Friendship Opportunity ................................................................. 33

Other Personality Characteristics........................................................... 33

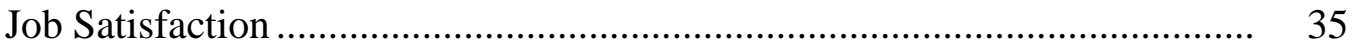

Demographic Characteristics ........................................................... 36

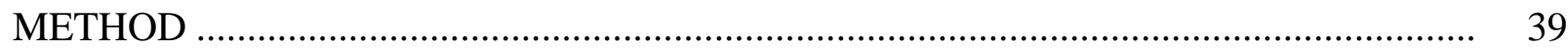

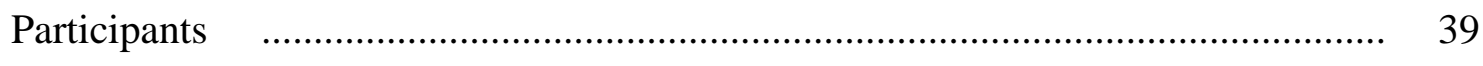

Design and Procedure ........................................................................... 41

Social Network Analysis................................................................... 43

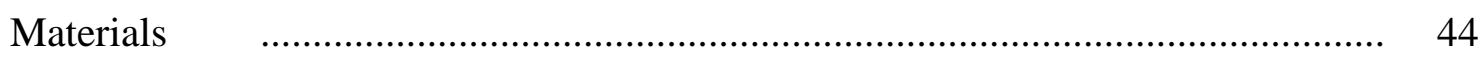

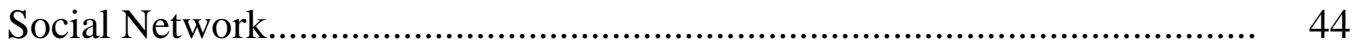


Organizational Commitment............................................................ 45

Workplace Friendship Opportunity .......................................................... 45

Other Work Investments .................................................................. 45

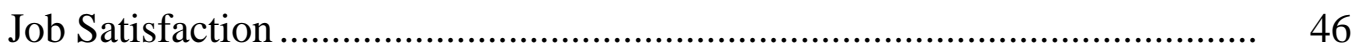

Intentions to Quit .......................................................................... 46

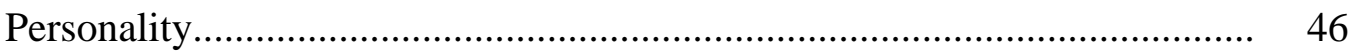

Demographic Characteristics ......................................................... 47

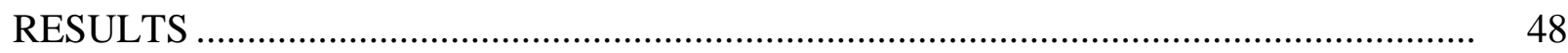

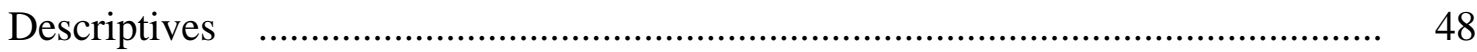

Work Constructs ...................................................................... 48

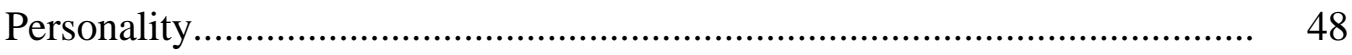

Social Network............................................................................ 49

Distribution Properties ...................................................................... 49

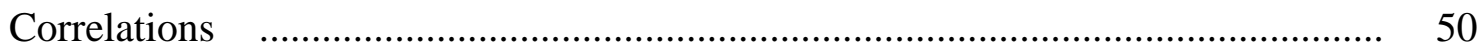

Continuance Commitment - Personal Sacrifice ................................... 50

Intent to Quit .......................................................................... 50

Social Network............................................................................ 50

Regression Analyses ........................................................................... 51

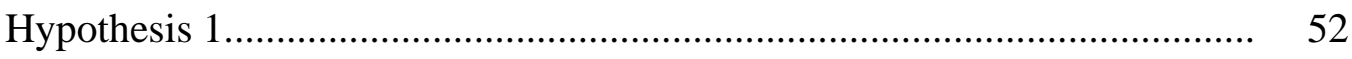

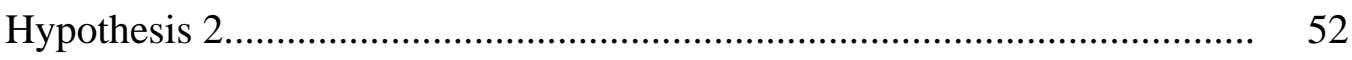

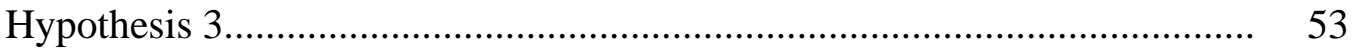

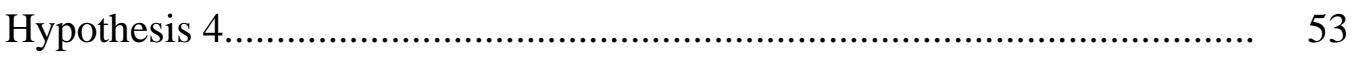

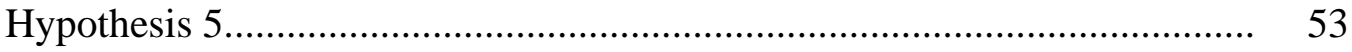




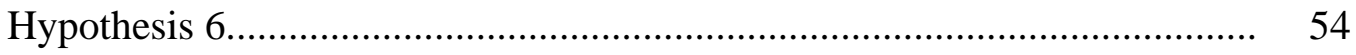

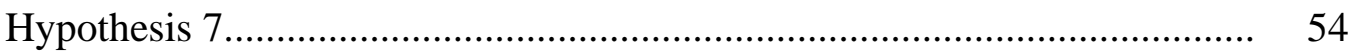

Hypothesis 8.................................................................................... 54

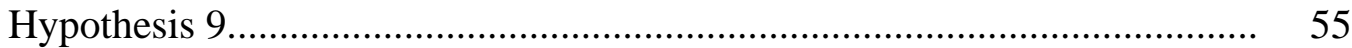

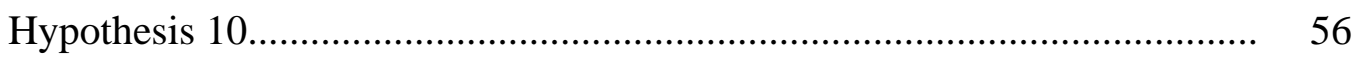

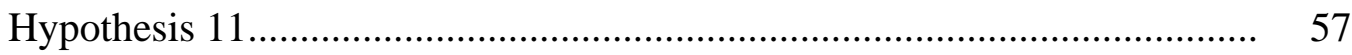

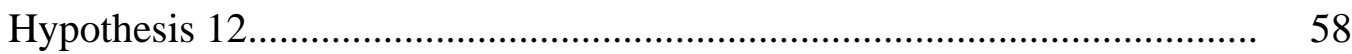

Hypothesis 13.................................................................................... 59

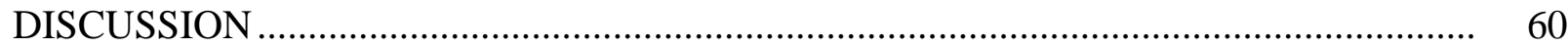

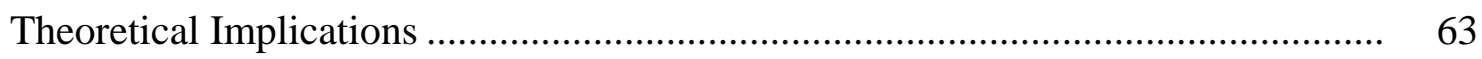

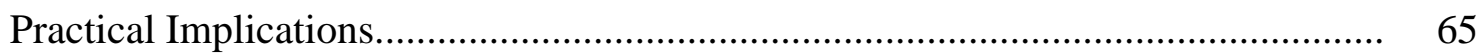

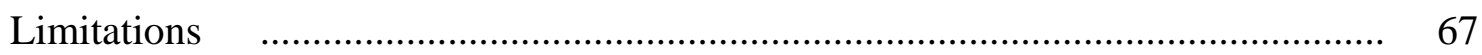

Future Research .....................................................................................

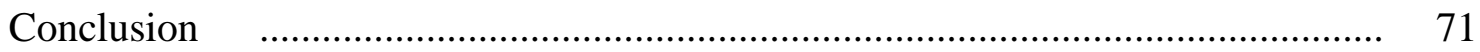

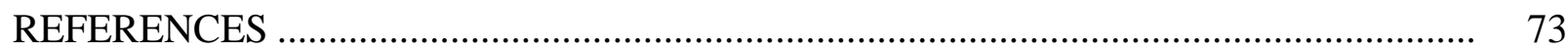

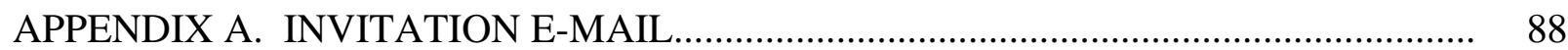

APPENDIX B. REMINDER E-MAILS ................................................................. 90

APPENDIX C. PARTICIPANT SURVEY ……………….......................................... 92 


\section{LIST OF TABLES}

Table

Page

1 Descriptions of Participating Organizations

2 Means, Standard Deviations, and Pearson Intercorrelations of All Continuous and

Dichotomous Variables.

3 Means and Standard Deviations of all Continuous and Dichotomous Variables by Organization

4 Testing Hypothesis 1: Work Relationships (i.e., Network Size, Relative Network Status, Network Relationship Quality, and Network Interaction) Will Predict Incremental Variance in Personal Sacrifice after Accounting for Job Satisfaction, Job Alternatives, and Other Work Investments

$5 \quad$ Testing Hypothesis 2: Larger Social Networks, Networks Comprised of Relatively Higher Status Individuals, Networks Comprised of Higher Quality Relationships, and More Frequent Interaction with Network Contacts Will Predict Incremental Variance in Personal Sacrifice after Accounting for Other Work Investments

$6 \quad$ Testing Hypothesis 3: Larger Social Networks, Networks Comprised of Relatively Higher Status Individuals, Networks Comprised of Higher Quality Relationships, and More Frequent Interaction with Network Contacts Will Predict Incremental Variance in Intentions to Quit after Accounting for Personal Sacrifice

$7 \quad$ Testing Hypothesis 4: Network Size Will Positively Predict the Size of the Personal Sacrifice Associated with Leaving One’s Job 
8 Testing Hypothesis 5: Relative Network Status Will Positively Predict the Size of the Personal Sacrifice Associated with Leaving One’s Job

$9 \quad$ Testing Hypothesis 6: Network Interaction Will Positively Predict the Size of the Personal Sacrifice Associated with Leaving One’s Job

10 Testing Hypothesis 7: Network Relationship Quality Will Positively Predict the Size of the Personal Sacrifice Associated with Leaving One’s Job.

11 Testing Hypothesis 8: Need for Affiliation Will Moderate the Relationship between Network Size and Personal Sacrifice.....

12 Testing Hypothesis 8: Need for Affiliation Will Moderate the Relationship between Relative Network Status and Personal Sacrifice

13 Testing Hypothesis 9: Workplace Friendship Opportunity Will Moderate the Relationship between Network Size and Personal Sacrifice 138

14 Testing Hypothesis 9: Workplace Friendship Opportunity Will Moderate the Relationship between Relative Network Status and Personal Sacrifice 139

15 Testing Hypothesis 10: Extraversion and Agreeableness Will Positively Predict Network Size, Relative Network Status, Network Interaction, and Network Relationship Quality

16 Testing Hypothesis 11: An Internal Locus of Control Will Positively Predict Network Size, Relative Network Status, Network Interaction, and Network Relationship Quality .....

17 Testing Hypothesis 12: The Relationship between Locus of Control and Personal Sacrifice Will Be Mediated by Network Size, Relative Network Status, Network Interaction, and Network Relationship Quality 
18 Testing Hypothesis 13: Job Satisfaction Will Predict the Size of the Personal Sacrifice Associated with Leaving One’s Job.................................................................. 144

19 Summary of Regression Tests Sorted by Results ............................................ 145 


\section{INTRODUCTION}

The concept of organizational commitment, commonly defined as “a psychological link between the employee and his or her organization that makes it less likely that the employee will voluntarily leave the organization” (Allen \& Meyer, 1996, p. 252), has been a prevalent topic of study in organizational research in recent years. As this definition implies, organizational commitment is important in large part because it is an antecedent of employee turnover (e.g., Arnold \& Feldman, 1982; Koch \& Steers, 1978; Porter, Steers, Mowday, \& Boulian, 1974). Some researchers have reported organizational commitment to better predict turnover than job satisfaction (Koch \& Steers, 1978; Steers, 1977), another commonly researched job attitude. It has also been shown to be an antecedent of other important work behaviors, such as absenteeism and tardiness (e.g., Blau, 1986; Gellatly, 1995; Meyer, Allen \& Smith, 1993), task performance (e.g., Meyer et al., 1993; Randall, 1990; Saks, 1995), and contextual performance (i.e., extra-role behavior or organizational citizenship behavior; Borman \& Motowidlo, 1993; Gregersen, 1993; Organ \& Ryan, 1995).

In addition to its many relationships with other constructs and behaviors, organizational commitment has been shown to be a multifaceted construct that can take on several different forms. In particular, the three dimensional conceptualization of organizational commitment proposed by Meyer and Allen (1991) has become one of the most popular models. This model proposes three forms of organizational commitment: affective, continuance, and normative. In short, individuals with strong affective commitment remain with their organization because they want to, those with strong continuance commitment remain because they need to, and those with strong normative commitment remain because they feel they ought to do so (Meyer et al., 1993). 
Although Meyer and Allen’s model of commitment is in general comprehensive and well-established, the causes and conceptualization of continuance commitment have been restricted almost exclusively to financial issues or investments. This has resulted in the neglect of a potentially important determinant of continuance commitment: the impact of work relationships (i.e., work-related, non-romantic associations). As Sheldon concludes in her 1971 work on organizational commitment, "both investments and [social] involvements are a part of the motivational pattern that produces identification of the professional with the organization.... Without social involvements, a withdrawal from commitment to the organization appears in spite of increased investments” (p. 149). Given that the current conception of continuance commitment has limited ability to predict important work outcomes when considered alone, as found by Meyer, Stanley, Herscovitch, and Topolnytsky’s (2002) recent meta-analysis of organizational commitment (affective and normative commitment showed much stronger relationships with almost all outcomes, with continuance commitment often showing weak relationships with outcomes), it seems reasonable that this form of commitment may be conceptually incomplete. Affective and normative commitment may also be influenced by work relationships; however, the focus of this study is on work relationships as investments, which is specific only to the construct of continuance commitment. Therefore, the focus of this study will be on the contribution of work relationships to continuance commitment alone.

To establish the role and importance of this component to continuance commitment, the three forms of Meyer and Allen’s theory of organizational commitment, including their antecedents and psychological processes, will be outlined, with continuance commitment discussed in the greatest detail. Work relationships will be discussed and their importance will be demonstrated. The investment model (Rusbult, 1980; Farrell \& Rusbult, 1981), a model 
borrowed from the interpersonal relationships literature that is conceptually applicable to work relationships, will be explained. Finally, these components will be integrated to show how work relationships should be included in future conceptualizations of continuance commitment. After the theoretical groundwork has been laid, the goal of this study is to empirically demonstrate that work relationships contribute to the explanation of continuance commitment above and beyond that explained by other continuance commitment factors.

\section{Affective Commitment}

Many different researchers have conceptualized organizational commitment in a manner indicating that employees maintain employment with an organization because they want to do so (e.g., Buchanan, 1974; Hall, Schneider, \& Nygren, 1970; Jaros, Jermier, Koehler, \& Sincich, 1993; Kanter, 1968; Mayer \& Schoorman, 1992; Mowday, Porter, \& Steers, 1982; O’Reilly \& Chatman, 1986; Penley \& Gould, 1988; Sheldon, 1971). Meyer and Allen $(1991,1997)$ have unified these characterizations of organizational commitment into one form of organizational commitment: affective commitment. This form denotes "an emotional attachment to, identification with, and involvement in the organization” (Meyer et al., 2002, p. 21).

Meyer and Herscovitch (2001) assert that the development of the three forms of organizational commitment is predicated upon the mind-set of the individual in question. That is, factors that play a part in developing commitment (i.e., antecedents of commitment) do so by impacting “one or more of the mind-sets that bind an individual to a course of action of relevance to a particular target” (Meyer \& Herscovitch, 2001, p. 315). In the case of affective commitment, the mind-set of relevance is desire: individuals with this type of commitment desire or want to maintain their current course of action (i.e., current employment). 
Antecedents of affective commitment. The set of factors identified as antecedents to affective commitment with the greatest amount of research support are those related to work experience. Specifically, individuals who perceive high organizational support (e.g., Eisenberger, Huntington, Hutchison, \& Sowa, 1986; Sanchez, Korbin, \& Viscarra, 1995), supportiveness of a leader or supervisor as measured by leader consideration (e.g., DeCotiis \& Summers, 1987; Mathieu \& Zajac, 1990), supervisor supportiveness (e.g., Mottaz, 1988), transformational and transactional leadership (e.g., Bycio, Hackett, \& Allen, 1995) and leader-member exchange (e.g., Major, Kozlowski, Chao, \& Gardner, 1995) are more likely to be affectively committed. Additionally, fair treatment operationalized as procedural justice (e.g., Konovsky \& Cropanzano, 1991), interactional justice (Meyer et al., 2002) and distributive justice (Meyer et al., 2002), as well as the absence of role ambiguity and role conflict (e.g., Adkins, 1995; DeCotiis \& Summers, 1987) have also been associated with higher affective commitment.

Finally, organizations that provide a sense of personal importance and competence for their employees are more likely to stimulate affective commitment. Some means of accomplishing this are participation in decision-making (e.g., Rhodes \& Steers, 1981), greater task autonomy (e.g., Dunham, Grube, \& Castaneda, 1994), and greater job scope (e.g., Mathieu \& Zajac, 1990; Meyer, Bobocel, \& Allen, 1991). Lastly, some significant positive relationships between the following personal characteristics and affective commitment have been identified (Mathieu \& Zajac, 1990; Meyer et al., 2002): age, organization tenure, position tenure, internal locus of control, and task self-efficacy.

Psychological processes involved in development of affective commitment. Although the empirical evidence is rather limited and somewhat mixed, several processes are hypothesized to operate in the development of affective commitment. One hypothesis is that affective 
commitment develops on the basis of psychologically rewarding experiences (Meyer \& Allen, 1997). These include satisfying employees’ personal needs, meeting their expectations, and allowing them to achieve their goals (e.g., Wanous, Poland, Premack, \& Davis, 1992). Another is that affective commitment develops as a result of employees needing to retrospectively justify their choice of employment (e.g., Kiesler, 1971; Meyer et al., 1991). A final hypothesis relates to the role of causal attributions. If employees attribute the organization to be the source of positive work experiences or desirable human resource practices and the motivation of these practices to be honorable (i.e., “motivated by concern and respect for employees” [Meyer \& Allen, 1997, p. 55]), then these experiences are more likely to lead to affective commitment (e.g., Koys, 1988, 1991).

\section{Normative Commitment}

Although less common than affective commitment, another prevalent conceptualization of organizational commitment is that employees feel morally obligated to be committed to their organization (e.g., Marsh \& Mannari, 1977; Scholl, 1981; Wiener, 1982; Wiener \& Gechman, 1977). Meyer et al. (2002) named this form of commitment normative commitment and define it as “a perceived obligation to remain in the organization” (p. 21).

The mind-set of relevance for normative commitment is obligation (Meyer \& Herscovitch, 2001): individuals with this type of commitment feel that they should maintain their current course of action (i.e., employment). Employees with strong normative commitment believe remaining with the organization is the "right and moral" thing to do (Meyer \& Allen, 1991; Scholl, 1981; Wiener, 1982).

Antecedents of normative commitment. Of the three forms of commitment, this form has received the least amount of research attention; however, the limited existing research has 
identified some significant antecedents of normative commitment. In their meta-analysis of organizational commitment, similar to affective commitment, Meyer et al. (2002) found that several demographic characteristics, age, organizational tenure, and position tenure, significantly predict normative commitment. They also found organizational support, transformational leadership, role ambiguity, role conflict, interactional justice, distributive justice, procedural justice, job investment, and transferability of skills to be significant predictors.

Psychological processes involved in development of normative commitment. In his conceptual development of normative commitment, Wiener (1982) asserted that early socialization pressures from childhood and early organizational experiences contribute to its development. Psychological processes such as conditioning and modeling inform individuals of what family, culture, and the organization expect from them. Over time, individuals internalize these expectations. In this case of work, these expectations are expressed as believing it is appropriate and "right" to possess loyalty toward the organization. Others (Meyer \& Allen, 1991; Scholl, 1981) have suggested that when the organization makes investments in employees that are difficult for employees to reciprocate (e.g., tuition benefits, special policies for the employment or health of family members) employees may develop a sense of indebtedness or obligation toward the organization, leading to normative commitment.

Finally, although it has yet to be formally investigated, the development of normative commitment may be attributable to the psychological contract between an employee and the organization. Psychological contracts are subjective "beliefs in reciprocal and promised obligations between employee and employer” (Robinson \& Rousseau, 1994, p. 245), which if violated can lead to negative consequences for the violator (e.g., distrust, disappointment, end of the employment relationship). Whether an employer does or does not fulfill the psychological 
contract, as conceived by the employee, may lead to the furtherance or hindrance, respectively, of that employee's feelings of obligation and the appropriateness of continuing their current employment relationship (i.e., normative commitment).

\section{Continuance Commitment}

Continuance commitment "refers to the awareness of the costs associated with leaving the organization” (Meyer \& Allen, 1991, p. 67). Individuals with high continuance commitment remain with their organizations because they perceive the costs of leaving to be too great. As the definition states, it is essential for the individual to be consciously aware of the costs of leaving; otherwise, that individual will not be able to make active decisions to prevent incurring those costs (Becker, 1960; Meyer \& Allen, 1997). Therefore, the relevant mind-set for this form of commitment is need: the need to avoid the perceived cost that would result from discontinuing the current course of action (i.e., current employment). This leads to the belief that they have to stay with the organization. Other researchers that have studied this form of commitment include Becker (1960, 1964), Kanter (1968), Hrebiniak and Alluto (1972), O’Reilly and Chatman (1986), Ritzer and Trice (1969), and Stevens, Beyer, and Trice (1978).

Antecedents of continuance commitment. The development of continuance commitment occurs "as a result of any action or event that increases the cost of leaving the organization, provided the employee recognizes that these costs have been incurred” (Meyer \& Allen, 1997, p. 56). Costs associated with leaving an organization may include a wide variety of entities, some of which are measurable and others which are more intangible. Some measurable losses may be in the areas of salary, accrued vacation, retirement investment or pension plan, health insurance, life insurance, and company-sponsored items such as a vehicle or cellular telephone. Intangible losses may include transferability of skills, transferability of education, seniority, status, and job 
security. Aside from the tangibility of cost, another dimension to the development of continuance commitment is whether the factors are work-related or nonwork-related (Meyer \& Allen, 1997). The aforementioned items are all work related, as they are inextricable and resultant from the job itself. Nonwork-related factors may be ability to relocate, commute time, flexibility regarding work hours or working from home, employment status of one’s spouse, and children.

Regarding other potential antecedents, Meyer et al. (2002) found that continuance commitment was significantly predicted by age, education, organizational tenure, and position tenure, as well as organizational support, transformational leadership, role ambiguity, role conflict, and interactional justice.

Psychological processes involved in development of continuance commitment. As previously mentioned, the psychological recognition of having incurred costs of leaving an organization is the critical process involved in developing continuance commitment. Other psychological processes that may be involved include various perceptions: perceptions about transferability of their education (Lee, 1992, as cited in Meyer \& Allen, 1997) or skills (Allen \& Meyer, 1990) to other organizations, perceptions of available employment opportunities (Meyer et al., 1991), perceived attractiveness of available employment opportunities (Whitener \& Walz, 1993), and perception of one’s provider status (i.e., only or primary wage earner vs. secondary wage earner; Jayne, 1994).

Dimensionality of continuance commitment. McGee and Ford (1987) demonstrated that Meyer and Allen's scale measuring continuance commitment is actually composed of two dimensions: commitment based on the personal sacrifice associated with leaving the organization (i.e., loss of investments), and commitment based on few existing employment alternatives. As the focus of this study is on work relationships as investments, the contribution of work 
relationships to the personal sacrifice dimension of continuance commitment will be the primary dimension of study.

Before discussing the two dimensions of continuance commitment further, the concepts of investment and sacrifice will be clarified. An investment is something accumulated over time with the hope that a future return will be gained from it. To change one's behavior such that the investment item can no longer be accumulated and no future return can be gained from it is considered undesirable, and a loss. Investments in the workplace include the aforementioned examples (e.g., pension, accrued vacation, seniority, salary, etc.). These items are work investments because they gain in value over time but are lost when an employee leaves an organization. Sacrifice is linked to the concept of investment in that it is the act of giving up or losing something of value (i.e., an investment). These two concepts are related to commitment because the desire to avoid sacrificing work investments leads to increased continuance commitment.

The origin of the investment dimension of continuance commitment, and indeed the foundation of most versions of cost-based or calculative commitment, is credited to Becker's (1960) side-bet theory. Becker defined the concept of commitment as engaging in "consistent lines of activity” (p. 33), which in the case of organizational commitment connotes maintaining employment with a given organization. This commitment occurs as a result of an individual making a "side bet," which is to stake something of value to him or her (i.e., investments) on being consistent in their present behavior. The side bet is made because the individual believes that the chosen line of activity will be rewarding or satisfactory. He referred to the process of deciding whether or not to maintain commitment (i.e., employment) at a certain time as the "final bargaining session” (p. 35). To act inconsistently in the final bargaining session (i.e., to 
discontinue employment with that organization) would result in losing the side bet (i.e., the staked valuables), which may be a loss so great that it is not a feasible alternative. These valuables include anything that the individual considers important and may include any of the previously mentioned entities (e.g., retirement pension, accrued vacation time).

The other dimension of continuance commitment, a lack of existing employment alternatives, was hinted at by Becker (1960) when he discusses how side bets can inadvertently constrain future behavior, in particular the alternatives that one is willing or able to accept. However, this dimension is more firmly rooted in Thibaut and Kelley's discussion of the principles of interdependence theory (1959). In brief, interdependence theory states that an individual will only remain committed to a relationship as long as the outcomes received are greater than the outcomes available from the best available alternative. Outcomes are determined by taking the difference between a relationship's rewards and costs and the goal is to maximize outcomes, which effectively means to maximize rewards while minimizing costs. The concepts underlying this dimension were more fully developed in Rusbult’s (1980) investment model, which will be discussed shortly.

In almost all literature pertaining to continuance commitment, it is depicted as having a financial basis, with little regard to other types of losses or costs that might be incurred as a result of leaving an organization. Another type of loss or cost of leaving an organization is the loss of work relationships, which was mentioned by Becker in a later work (1964) and some others (e.g., Alutto, Hrebiniak, \& Alonso, 1973; Hrebiniak \& Alluto, 1972; Kanter, 1968; Meyer \& Allen, 1991; Sheldon, 1971). A few authors have recognized the potential impact of work relationships by incorporating it into their studies. In their studies of organizational commitment, Alutto et al. (1973) and Hrebiniak and Alluto (1972) included a set of items measuring co- 
worker friendliness in their organizational commitment scale. However, the role of work relationships in predicting commitment is not elucidated by this study because they offer virtually no explanation for the inclusion of this concept, nor do they discuss the findings of these items in specific apart from the other items in their commitment scale. Sheldon (1971), on the other hand, provides a more in depth study of work relationships and commitment and was also the first to suggest that work relationships can be viewed as investments. Before expanding on Sheldon's study and its findings, a discussion of what work relationships are and the existing research on the subject is necessary to put it in context.

\section{Work Relationships}

Before discussing work relationships in detail, a point of clarification is necessary. Existing research on work affiliations includes studies of both work relationships and also work friendships. The focus on this study is on the more general form of work relationships, which may include friendships. Both lines of research have important contributions to the theoretical background, development and justification for this study. Therefore, when discussing existing research, research on relationships as well as friendships will be included.

Definition of work relationships. The word relationship literally means "a particular type of connection between people related to or having dealings with each other” (Berube, Costello, Jost, Ellis, \& Severynse, 1997). Sheldon (1971), one of the few researchers to empirically study the link between work relationships (or, as she called them, "social involvements") and organizational commitment, provided the following definition: "Social involvements refer to interaction with and identification with other members of the organization” (p. 144). What we learn from these definitions is that a work relationship involves a connection between persons 
who interact, identify, and deal with one another. No personal relationship is necessary in this paradigm; however, they are allowed.

Sheldon's definition implies that one may only have work relationships with other members of the same organization. Today, however, it is common for employees to have what might be considered work relationships with individuals outside of the organization, such as customers, clients, or suppliers (Landy \& Conte, 2004). Additionally, these definitions are sufficiently broad in that romantic relationships may fall under their umbrellas. Romantic relationships have different boundaries, norms, expectations, and outcomes (Myers, 1996; Pinder, 1998) than platonic relationships (the type of relationships that are the focus of this study), which makes them qualitatively different (Berman, West, \& Richter, 2002). As a result, the definition of work relationships that will be used in this study will be expanded to include all persons with whom an individual has work-related contact, and will exclude romantic relationships. Therefore, the definition of work relationships that incorporates all of these components and will be used for purposes of this study is as follows: platonic interactions and identifications attained through work-related contact. This definition is comprehensive in that it can include work-related relationships between persons of any status both within and without the organization itself. It may also include relationships that are friendships and relationships that are less personal.

Relationship development. There are many factors that increase the likelihood of relationship development, including proximity, interaction, and similarity (Myers, 1996; Sias, Heath, Perry, Silva, \& Fix, 2004). Social psychological research commonly finds that we are more likely to develop relationships with those in close proximity to ourselves (Berscheid, 1985; Clarke, 1952), and with whom we interact more often (Myers, 1996). These situations give the 
individuals more opportunity to get to know one another, discover commonalities, and exchange rewards. Similarity between individuals is also likely to precipitate a relationship because humans have a tendency to gravitate toward those who share their attitudes, beliefs, values, and interests (Burgess \& Wallin, 1943; Kandel, 1978; Myers, 1996). In the traditional workplace, these factors are all present. Employees are in close physical proximity to one another during the work day, interaction is often required among employees for work-related purposes, and simply by virtue of working in the same organization gives employees similarities upon which relationships can be built.

Importance of studying work relationships. According to Pinder (1998), it is important to examine relationships at work for the following reason:

By definition, work organizations consist of two or more persons, making the possibility for human interaction immediately and inherently possible....Moreover,...there are certain features of many or most organizations that actually compel or motivate their members to affiliate with one another (p. 135).

Beyond the structural characteristics of work life that allow and sometimes force interpersonal interaction, the intrinsic human need for affiliation is strong (Baumeister \& Leary, 1995; Hill, 1987). This need often leads individuals to form voluntary and meaningful relationships with others beyond that which is compelled by the organization. According to Hill, such affiliations or relationships can provide many rewards and satisfy many needs, including attention, praise, reduction of negative affect (i.e., fear and stress) through social contact, and social comparison. Additionally, Winstead, Derlega, Montgomery, and Pilkington (1995) note that friendships at work can promote the general well-being of those involved in the relationship, job satisfaction (including the benefits to the organization associated with job satisfaction such as 
lower absenteeism and turnover; Ilgen \& Hollenback, 1977), and emotional support and encouragement. Kram and Isabella (1985) identified several other positive outcomes from peer work relationships, including social support, job-related feedback, personal feedback, information sharing, and career strategizing. Others have found enjoyment (Fine, 1986), creativity (Yager, 1997), and career development and advancement (Graen \& Scandura, 1987) to be common outcomes.

The previously mentioned factors of relationship development make the development of both obligatory and voluntary work relationships probable and even expected. In sum, humans naturally have a need to affiliate with others, the workplace provides the opportunity and often the necessity for affiliation, and there are many possible outcomes for those affiliating with others. Therefore, it is important to study this natural workplace phenomenon.

Consequences of relationship loss. Just as there are benefits to having relationships at work, there are also consequences of losing those relationships. A study by Sias et al. (2004) focused on the deterioration of work friendships, particularly consequences of the deterioration. They found that work relationships may serve as information-sharing, resource-distributing, decision-making, and support systems. Such systems may provide social support, enjoyment, and career development to the relationship participants. When those relationships deteriorate, however, they found that emotional stress, turnover, and hindered job performance are potential outcomes.

Krackhardt and Porter (1985) also studied relationship loss at work, but from the alternate perspective: the effect on the "stayers" as opposed to the "leavers." They found that the closer the relationship was between the stayer and the leaver, the more likely the stayer was to report increased job satisfaction/organizational commitment (JS/OC). Although this result may seem 
counterintuitive, the authors had hypothesized this result using a combination of balance theory and psychological justification. Heider's balance theory (1958) focuses on the valence of feelings between three targets in a system, with the targets consisting of two individuals and an outside object. In this case, the two individuals represent a stayer and a leaver, and the outside object consists of JS/OC. For this system to function, Heider hypothesized that there must be balance between the three targets, and that if there is imbalance the involved persons will take action to create balance. Taking for granted that the stayer and leaver have positive feelings toward one another, when the leaver leaves the organization, balance can be accomplished in one of three scenarios. Two of these scenarios were directly proposed by Heider and one was not but is inferable from later research on psychological justification (e.g., Staw, 1980):

1. The stayer likes the leaver, and both stayer and leaver have positive JS/OC.

2. The stayer likes the leaver, and both stayer and leaver have negative JS/OC.

3. The stayer likes the leaver, the leaver has negative JS/OC, and the stayer has increasingly positive JS/OC.

As previously mentioned, Krackhardt and Porter (1985) found support for the third situation. They hypothesized that this situation would develop in order to justify the stayer's choice to stay with the organization in the face of his or her friend who has negative feelings toward the organization. These findings demonstrate that leaving an organization can have psychological and behavioral consequences for both those who leave and those who stay.

The issue of relationship loss is crucial to understanding how work relationships can be considered an investment that may be lost. When an individual leaves an organization those relationships may deteriorate or even dissolve, leading to either negative or positive consequences for the individuals involved. 
Relationship forms and exchange theories. Such involvements or relationships, can take a variety of forms. These relationships may be between coworkers, team members, or a supervisor and subordinate. It may be an association solely based on work or it may be a more intimate, personal friendship. It may only exist in the work context or it may extend outside of the workplace. Regardless of the specific nature and depth of work relationships, the quality of those relationships can have a profound effect on employees and their work experience. There is an existing research framework on the different types of relationship forms that an individual may have. These research topics are widely known as leader-member exchange (LMX; Dansereau, Graen, \& Haga, 1975), and the related topics of coworker exchange (CMX; Seers, 1989), team member exchange (TMX; Seers, 1989), and work group exchange (WGX; Dunegan, Tierney, \& Duchon, 1992).

LMX theory was developed by Dansereau et al. (1975), and it holds that leaders develop a unique relationship with each subordinate, and each of those relationships exists on a continuum ranging from low quality to high quality (Sherony \& Green, 2002). Low-quality LMX relationships typically only involve interactions that are essential to the employment contract (i.e., basic to the job), and they do not tend to enhance the subordinate's work experience. Alternatively, high-quality LMX relationships involve interactions that go beyond those essential to the employment contract; typically are characterized by positive and enhancing features such as mutual respect, trust, and autonomy; and often enhance the work experiences of both dyad members (Sherony \& Green). CMX, TMX, and WGX theories follow the same pattern as LMX, although TMX and GWX focus on a member's relationship with his or her team or work group as a whole as opposed to a relationship with another individual. 
Beyond the fact that these various exchanges play a significant role in the day-to-day work life of employees, there is also empirical evidence that these relationships can impact an employee’s job attitudes. Campion, Medsker, and Higgs (1993) and Cohen and Bailey (1997) found that relationships among team members can affect how those members feel about the team and their jobs. More specifically, Bhal and Ansari (1996), Sherony and Green (2002), Seers (1989), and Dunegan et al. (1992) have each found positive relationships between the type of worker exchange studied (LMX, CMX, TMX, and WGX, respectively) and various job attitudes, such as job satisfaction and organizational commitment. These attitudes are known from other research to relate to worker behaviors such as absenteeism, turnover (e.g., Nicholson, Wall, \& Lischeron, 1977), and organizational citizenship behavior (e.g., Podsakoff, MacKenzie, Paine, \& Bachrach, 2000). Liden, Wayne, and Sparrowe (2000) also found a direct relationship between both LMX and TMX and organizational commitment. This finding led them to conclude that not only are interpersonal relationships salient with respect to organizational commitment, but the support and guidance received from forming relationships with one’s supervisor and coworkers are important in determining levels of commitment.

In addition to the attitudinal consequences of LMX quality, there are other potential outcomes for the subordinate. In their meta-analysis of LMX, Gerstner and Day (1997) found that higher performance and lower intentions to quit are associated with high quality LMX, and Tierney, Farmer, and Graen (1999) found that higher subordinate creativity may result. These findings indicate that the quality of worker exchanges can have far reaching consequences on not only employee attitudes, but employee behaviors as well.

Beyond exchange theories. The research framework of LMX and related types of work exchange provides a firm base of knowledge on relationships at work, and also provides support 
for studying the relationship between work relationships and organizational commitment. However, the scope of these exchange theories is limited because they focus on individual, dyadic relationships between the worker and other individual or individuals with whom he or she is engaged in a formal, defined work affiliation. Workers may have simultaneous relationships with individuals above, below, and lateral to themselves, which when taken together form a constellation of relationships. It is this constellation, not merely one relationship, which shapes the impact of work relationships on organizational commitment and other outcomes of interest. For example, an employee may have a great relationship with his or her coworkers, but a poor one with his or her supervisor. Because these relationships exist simultaneously, they should be considered simultaneously. The goal of this study is to more fully understand the role of all work relationships in influencing continuance commitment. Therefore, it is important to study the whole constellation of formal and informal, defined and undefined, multilevel work relationships in which that individual is engaged, as opposed to specific relationships taken one at a time. Existing research on work relationships. Research on the connection between work relationships and employment decisions (e.g., staying, quitting) is quite scarce. However, there is one existing study from the field of sociology, Miller and Labovitz (1973), which provides strong evidence for the importance of these relationships. Miller and Labovitz had the opportunity to study the influences on the natural turnover behaviors of employees during an organizational division. A splinter group of employees were leaving their original organization to form their own organization, leaving employees of the original organization with three choices: to remain with the original organization, to leave the original organization to work for the new organization created by the splinter group, or to leave the situation altogether. The authors studied the effects of three sets of influences on individual employment decisions: psychological 
influences (i.e., job satisfaction and job tension), relational influences (i.e., social rewards, social costs, status consistency), and extra-organizational influences (i.e., marital status, professional commitment, community involvement). As the topic of interest in this paper is work relationships, only the results regarding the relational influences will be discussed.

Regarding the relational influences, Miller and Labovitz (1973) suggested that “individual decisions should be measurably affected by attempts to preserve, improve or escape existing social relationships, depending on whether these relationships are rewarding or costly in exchange terms” (p. 559). Essentially, they proposed that employment decisions would be made on the basis of desires to maintain or possibly improve good work relationships, or to escape from undesirable work relationships. They focused on three types of work relationships: more highly esteemed coworkers (i.e., coworkers that they respect professionally and consider to be more “expert," knowledgeable, and likely to be helpful in critical situations), information contacts (i.e., workers who have strategic knowledge or better-than-average access to work information), and friends. They hypothesized that the probability that an individual will have left the original organization is directly related to the proportion of his/her more highly esteemed coworkers, information contacts, and friends who left. In other words, they hypothesized that individuals would stay or leave depending on which choice allowed them to preserve their rewarding social exchanges. To determine the individuals with whom each participant held such relationships, participants were asked to name the individuals that fell into each of the aforementioned relational categories.

The results of this study indicated strong support for all three of the hypotheses regarding relationships at work: very few participants made choices different than those made by their more highly esteemed coworkers, information contacts, and friends. A particularly notable 
finding was that not one participant remained at the original organization if most of the individuals that he or she named as relational contacts moved to the new organization (Miller \& Labovitz, 1973).

Work relationships and commitment. Now that some background on organizational commitment and work relationships has been provided, turning to the small amount of research relating commitment and work relationships is appropriate. As previously mentioned, Sheldon (1971) is one of the few researchers who has studied the role of work relationships in predicting organizational commitment. Consistent with Meyer and Allen’s (1991) conceptualization of continuance commitment, Sheldon hypothesized that investments would produce commitment to the organization. This is accomplished by an individual making decisions at various points during his or her career (e.g., choosing to remain in an organization), and over time these decisions may lead to unanticipated consequences, such as alternatives (i.e., other jobs) becoming less feasible. When that individual realizes he or she has been left with few if any options as a result of previous decisions, he or she may have no choice but to identify with the organization, ultimately producing commitment.

Sheldon (1971) used age, length of service in the organization, and position as measures of investment. She hypothesized that older individuals who had been with the organization longer and held higher positions would have more invested in the organization, and would therefore have higher commitment. Her second hypothesis was that social involvements, another type of investment, would also produce commitment to the organization, such that those with more social involvements would be more committed. She found that both investments and social involvements predict commitment, particularly when they occur in combination. This was specifically true for those respondents having medium length of service to the organization. In 
spite of the increased investments these respondents had accrued, social involvements were a differentiating factor (i.e., moderator) in determining whether or not they were committed to the organization.

Other existing research relating work relationships and commitment, although previously mentioned, will be described here. First, Liden et al.'s (2000) finding that both LMX and TMX are directly related to organizational commitment, in conjunction with their conclusion that the support and guidance received from forming work relationships are important in determining levels of commitment, supports studying the relationship between work relationships and commitment. Second, the primary outcome that we seek to predict and avoid by studying organizational commitment is turnover, and also its most predictive antecedent, intentions to quit. Gerstner and Day’s (1997) finding that high quality LMX is associated with lower intentions to quit, and Miller and Labovitz’s (1973) finding that individuals make employment decisions (i.e., turnover) based on the quality of their work relationships demonstrate a relationship between work relationships and the behavioral consequences of organizational commitment. These findings indicate that there is practical value in further understanding the effect of work relationships on organizational commitment.

Third, Miller and Labovitz’s (1973) findings also demonstrate that individuals recognize the cost of losing good work relationships, and therefore seek to avoid incurring this cost by taking action to preserve those relationships. This provides evidence that work relationships are viewed as investments, a conceptualization that may place work relationships under the umbrella of continuance commitment.

Finally, this conceptualization is supported by the construct of job embeddedness (Mitchell, Holtom, Lee, Sablynski, \& Erez, 2001), in particular the aspects of links and sacrifice 
on the job. Job embeddedness suggests that the more on-the-job links an individual has with others, the more that individual is bound to the job and organization. As the number of links increase, the ease of extracting oneself from the web of links becomes more difficult, undesirable, and costly. The aspect of sacrifice "captures the perceived cost of material or psychological benefits that may be forfeited by leaving a job” (Mitchell et al., 2001, p. 1105); the idea of having to give up work colleagues and friends when leaving an organization falls into this category. Just as with the links aspect, the more an employee would have to give up by leaving the more difficult it will be for that employee to leave. Mitchell et al. (2001) specifically points out similarities between their construct and the personal sacrifice dimension of continuance commitment. These parallels further demonstrate the conceptual resemblance between these constructs and providing additional support for the conceptual development of this study.

Although the construct of job embeddedness supports the conceptualization put forth in this study and may appear on the surface almost indistinguishable, there are important differences that should be noted. Regarding Mitchell et al.'s (2001) organizational links, this dimension focuses solely on the number of work links an employee has as a predictor of job embeddedness. Alternatively, this study will examine the quantity of work links but is more primarily concerned with the quality of those links with specific others in the workplace, including the employee’s supervisor, subordinates, coworkers, work associates, and work friends. Furthermore, the items used to assess the job embeddedness dimension of organizational links are in a biodata-type format (e.g., “How long have you worked for this company?”, “How many work teams are you on?”). This study, however, focuses on the attitudinal nature of how "linked" an employee feels to their fellow employees and how invested he or she feels in those relationships. 
Regarding organization-related sacrifice, the underlying premise is almost identical to the premise of continuance commitment. However, only one of the items measuring it comes close to capturing work relationships, "I feel that people at work respect me a great deal,” and only one other general item conceivably captures work relationships, "I would sacrifice a lot if I left this job.” This study goes beyond a general measure of workplace respect and sacrifice. It examines the relationship quality an employee has with specific individuals in their workplace and how those forfeited relationships transform into sacrifices when leaving a job.

Now that work relationships are established as investments and the connection between work relationships and organizational commitment is demonstrated, Rusbult's (1980) investment model, which will be used as one test of the premise of this study, will be presented.

\section{The Investment Model}

The model. As the theoretical importance of work relationships in the context of commitment has not yet been firmly established, it is helpful to look to other areas of psychology to build such a theoretical model. An existing model that can prove helpful in this process is a model that focuses on a parallel topic to organizational commitment, commitment to romantic relationships: the investment model (Rusbult, 1980). The basis of this model is rooted in social exchange theory (Blau, 1964) and interdependence theory (Thibaut \& Kelley, 1959). These theories, as previously mentioned, purport that in relationships individuals are generally motivated to maximize their rewards while minimizing their costs, and seek to be in relationships that allow them to accomplish that. The same motivation holds true for economic exchanges; however, social exchanges differ because the rewards and costs are inherently unspecified and diffuse, and therefore cannot be objectively measured (Blau, 1964). Rewards and costs in such exchanges are subjectively determined in the minds of those engaging in the exchange. This is a 
key consideration of how work relationships differ from other components of continuance commitment. Other components at an individual's current and future organizations such as financial investments can be objectively compared. Although an individual can form a subjective opinion regarding the rewards and costs of current work relationships, it is much more difficult to do so for future work relationships.

First, the investment model asserts that satisfaction with a relationship (SAT) is represented by the subtraction of the costs of the relationship (CST) and the individual's comparison level (CL; i.e., “...the standard against which the attractiveness of a relationship is evaluated....It represents the average relationship outcome value that the individual has come to expect...” [Rusbult, 1980, p. 173]) from the rewards of the relationship (REW):

$$
\mathrm{SAT}=\mathrm{REW}-\mathrm{CST}-\mathrm{CL}
$$

Therefore, satisfaction with a relationship should be greater when the rewards are high, the costs are low, and the comparison level is low.

Commitment to that relationship (COM), however, is somewhat more complex. The investment model purports that "commitment to a relationship increases with the passage of time in part because the resources 'put into' a relationship increase the costs of withdrawing from it" (Rusbult, 1980, p. 174). Resources put into the relationship, or investments, may include time, emotional energy, self-disclosures, or money, all of which are nonportable. As a result, the size of the investment into the relationship (INV) must be taken into account. Additionally, the quality of the alternatives to the current relationship (ALT; e.g., a romantic relationship with another person, no relationship) is another factor of commitment. Thus, the investment model of commitment is as follows:

$$
\mathrm{COM}=\mathrm{SAT}+\mathrm{INV}-\mathrm{ALT}
$$


Therefore, commitment to a relationship should be greater when satisfaction with that relationship is high, the investment in that relationship is high, and the quality of alternatives to that relationship is comparatively low.

Existing measures of each component (i.e., satisfaction, investments, alternatives, and commitment) can be used to test this model empirically. For example, if respondents who report high satisfaction, high investment, and low alternatives also report high commitment, and respondents who report low satisfaction, low investment, and high alternatives report low commitment, that could be taken as empirical support for this model.

Applications of the model. The investment model has also been applied successfully to organizational research (Farrell \& Rusbult, 1981; Rusbult \& Farrell, 1983). In this context, satisfaction with the relationship is equated with job satisfaction, commitment to the relationship is equated with organizational commitment, rewards of the relationship are rewards of the job (e.g., salary, benefits, vacation time, autonomy, opportunity for promotion), costs of the relationship are costs of the job (e.g., commuting time, undesirable shifts, unfair promotion practices), investments are resources inextricably connected to the job (e.g., organization-specific skills acquired, length of service, retirement programs), and quality of alternatives is the quality of other employment alternatives (e.g., other jobs, no job).

First, the ability of the investment model to predict job satisfaction, job commitment, and turnover was explored by Farrell and Rusbult (1981), and they found strong support for the application of the investment model in this context. Specifically, they found that job satisfaction was best predicted by the rewards and costs of the job, and job commitment was best predicted by a combination of rewards and costs, alternative value, and investment size. Second, Rusbult and Farrell (1983) conducted a longitudinal test of the investment model in an organizational 
context. They found that the impact of job rewards on satisfaction and commitment remained relatively constant over time, whereas the impact of costs and investment size exerted increasing influence on satisfaction and commitment over time.

These studies demonstrate that the investment model has useful applicability to organizational research, in particular to job satisfaction and organizational commitment. However, the original focus of the investment model, interpersonal relationships, was not carried over into these applications. Instead, the relationship in the organizational context was considered to be between the individual and the organization, and commitment to the relationship was characterized by remaining at the organization. I propose that the original focus of the investment model, interpersonal relationships, should be brought into the organizational context and used as an additional determinant of organizational commitment, specifically in the form of continuance commitment. Therefore, the first hypothesis of this study is that the investment model applied to work relationships will be supported.

Hypothesis 1: Work relationships (i.e., network size, relative network status, network relationship quality, network interaction) will predict incremental variance in personal sacrifice after accounting for job satisfaction, job alternatives, and other work investments. That is, the investment model as applied to work relationships will be supported.

It should be noted that investment size could be conceived both quantitatively and qualitatively. As this study perceives both measures to be important, investment size in terms of work relationships will be measured by examining both the number (i.e., network size) and 
quality of work relationships (i.e., relative network status, network relationship quality, network interaction).

Conclusions about Work Relationships and Commitment

It is possible to integrate these theories and ideas into a coherent framework. First, relationships at work are important to and influential with employees with regard to day-to-day interactions, job attitudes, and even turnover decisions. As a result, relationships at work, beyond individual relationship forms such as leader-member, deserve to be a topic of research in their own right. This will allow their strength and influence in various work situations to be assessed, and also their relationships with other work constructs, attitudes, and behaviors to be determined.

Second, relationships, as shown through the investment model, have investment qualities that in part significantly determine an individual's commitment to those relationships. These investments in relationships have been shown to occur in romantic relationships as well as in an employee's relationship with his or her organization. Therefore, in this context it is logical to extend the theory of investments to relationships at work. Relationships at work have their own investment qualities that become more important over time and as more effort is exerted to develop and improve the relationships. Thus, relationships at work are investments.

Third, as investments, relationships at work can be considered a cost of leaving an organization. If an individual chooses to leave an organization, unless their coworkers move to a new organization with that individual, the relationships he or she developed at the original organization are not transportable, and, from a work perspective, must be left behind.

Finally, relationships at work are a unique cost of leaving. Other costs of leaving, such as financial, usually can be quantified and potentially achieved at a different organization (e.g., pervious salary, medical benefits, retirement pension). Although the quality of work relationships 
may not be difficult to assess, quantifying such relationships is difficult if not impossible. Also, the financial situation of alternative employment can be assessed prior to accepting that employment (e.g., salary and benefits are known prior to offer acceptance). However, the quality of work relationships at a new organization is unpredictable and virtually impossible to assess prior to actually working in that new organization for a period of time. Therefore, given the demonstrated relationship between work relationships with organizational commitment and turnover, and as a unique cost of leaving an organization, relationships at work should be included as a component of continuance commitment. Likewise, they should be considered in future turnover models as a potential antecedent to turnover or staying behavior.

In sum, relationships at work are an important yet currently a rather neglected issue that deserve research attention. This topic deserves attention not only in the context of continuance commitment and turnover, but also on a more general basis so that their role in the workplace can be more accurately assessed and understood. Please note in all hypotheses that the phrase “work relationships” is used to refer to the conception of work relationships as investments, and includes the following constructs that will be explained in forthcoming sections: network size, relative network status, network interaction, and network relationship quality.

Hypothesis 2: Larger social networks, networks comprised of relatively higher status individuals, networks comprised of higher quality relationships, and more frequent interaction with network contacts will predict incremental variance in personal sacrifice after accounting for other work investments. 
Hypothesis 3: Larger social networks, networks comprised of relatively higher status individuals, networks comprised of higher quality relationships, and more frequent interaction with network contacts will predict incremental variance in intentions to quit after accounting for personal sacrifice.

\section{Work Relationship Constructs}

As previously mentioned, to fully understand the role of work relationships in the workplace, and more specifically their role in influencing continuance commitment, it is important to study the whole constellation of an individual's work relationships. To facilitate this understanding, several constructs from an analytic technique known as social network analysis are relevant. The focus of social network analysis is examining the relationships between social entities in a network (Wasserman \& Faust, 1994). This approach will provide us with more indepth information about each respondent's personal network of work relationships than simply asking direct questions about their network.

Network size. The first such construct is network size (Morrison, 2002; Podolny \& Baron, 1997), which is the number of individuals in a person's network. A larger network takes more time and effort to build, and indicates that the person has a larger stake in that network. Additionally, consistent with Sheldon (1971), a larger network reflects greater social involvement, which she found produced commitment to the organization. Therefore, a large network would be more costly to lose than a small network. 
Hypothesis 4: Network size will positively predict the size of the personal sacrifice associated with leaving one's job. That is, a larger network size will reflect having made a larger investment in one's job.

Relative network status. The second such construct is the relative network status (Ibarra, 1995), or the average relative position level of each respondent's network contacts. Contact status is one of the key dimensions that determine a social network's instrumental utility (Campbell, Marsden, \& Hurlbert, 1986; Ibarra, 1995). Having a network with relatively higher status contacts would be more costly to lose, as those individuals are more likely to have careerenhancing power.

Hypothesis 5: Relative network status will positively predict the size of the personal sacrifice associated with leaving one’s job. That is, a higher average relative network status will reflect having made a larger investment in one’s job.

Network interaction. Network interaction is the third relevant social network construct (Ibarra, 1995; Morrison, 2002). The closeness of two individuals, as measured by the frequency of their interaction and how close they perceive their relationship to be (i.e., friendship intimacy), may determine the propensity of the contact to transmit a benefit to the other individual (Ibarra, 1995). Close relationships are more likely to provide social and career support as well as fulfill psychosocial functions, such as enhancing one's sense of professional competence, identify, and effectiveness (Ibarra, 1995). Individuals that interact more frequently or perceive the relationship 
to be intimate are more likely to transmit such benefits. As a result, close networks are a greater investment and more costly to lose.

Hypothesis 6: Network interaction will positively predict the size of the personal sacrifice associated with leaving one’s job. That is, more frequent interaction will reflect having made a larger investment in one's job.

Network relationship quality. The fourth and final relevant social network construct is relationship quality. As previously noted and similar to the rationale for interaction, high quality work friendships can promote the general well-being of those involved in the relationship, job satisfaction (including the benefits to the organization associated with job satisfaction such as lower absenteeism and turnover; Ilgen \& Hollenback, 1977), as well as emotional support and encouragement (Winstead et al., 1995). Findings from the exchange literature also support the importance of high quality work relationships to commitment; several researchers have found positive relationships between various types of work exchange (i.e., LMX, CMX, TMX, and WGX) and organizational commitment (e.g., Liden et al., 2000; Sherony \& Green, 2002). In sum, the quality of an individual's work relationships can provide many benefits, and such relationships are more costly to forfeit.

Hypothesis 7: Network relationship quality will positively predict the size of the personal sacrifice associated with leaving one’s job. That is, better relationship quality will reflect having made a larger investment in one’s job. 


\section{Additional Constructs}

As previously mentioned, several demographic and dispositional characteristics have been identified as predictors of organizational commitment. Many of these characteristics are also related to work relationships, in that they may predict the need for, strength of, or ability to build and maintain such relationships. Given that, to uncover the relationship between work relationships and organizational commitment and understand what individual differences may explain, moderate, or mediate that relationship, it is necessary to measure these other related constructs. All constructs discussed below will be measured in this study.

Need for affiliation. The first such construct is need for affiliation, or more generally affiliation motivation. Murray (1938), an early researcher on the topic, defined need for affiliation as the tendency to receive gratification from harmonious relationships and from a sense of communion (as cited in Hill, 1987). Put more simply, it is the desire for social contact and according to Hill (1987) “the motivation for social contact can be considered a central influence on human behavior” (p. 1008). Work relationships are a form of social contact; therefore, they are a manifestation of need for affiliation. As a result, differences in need for affiliation may lead to different levels of interest, ability, and need for developing work relationships. More specifically, those with a high need for affiliation may be more likely to have a stronger relationship between work relationships and organizational commitment.

Hypothesis 8: Need for affiliation will moderate the relationship between work relationships (i.e., network size, relative network status, network interaction, network relationship quality) and personal sacrifice. That is, network size, relative network status, 
network interaction, and network relationship quality will be more strongly related to personal sacrifice among those with high need for affiliation.

Friendship opportunity. The opportunity for workplace friendship is an important factor to consider in this study. Friendship opportunity, at least in part, is likely to have a direct effect on both the number and quality of friends a given individual is able to develop in the workplace. As a result, similar to need for affiliation it is important to control for this factor when examining the number and quality of work relationships and using that to predict outcomes of interest.

Hypothesis 9: Workplace friendship opportunity will moderate the relationship between work relationships (i.e., network size, relative network status, network interaction, network relationship quality) and personal sacrifice. That is, network size, relative network status, network interaction, and network relationship quality will be more strongly related to personal sacrifice among those with greater workplace friendship opportunities.

Other personality characteristics. There are numerous existing studies that have found relationships between the big five personality characteristics and relationships or friendships. Agreeableness has been shown to contribute to adult friendship involvement (Heyl, 2004). Berry, Willingham, and Thayer (2000) found extraversion and agreeableness to predict friendship quality. Social support, defined by Landy and Conte (2004) as "the comfort, assistance, or information an individual receives through formal or informal contacts with individuals or groups” (p. 579), can be considered a characteristic of positive, high quality relationships, and 
Sarason and Sarason (1985) found that low social support was associated with lower extraversion. Finally, Mount, Barrick, and Stewart (1998) found that agreeableness is positively associated with job performance in jobs involving interpersonal interactions, which connotes that this characteristic promotes positive interpersonal interactions on the job.

Two studies have found a relationship between personality characteristics and organizational commitment (Erdheim, Wang, \& Zickar, 2006; Naquin \& Holton, 2002). They both found a significant negative correlation between extraversion and continuance commitment and no relationship between agreeableness and continuance commitment. These findings signify that these two big-five personality characteristics, agreeableness and extraversion, may have an opposing relationship with work relationships and continuance commitment. This may be the case because having work relationships is often desired, fulfills the basic human need for affiliation, and may provide rewards. On the other hand, the basis of continuance commitment is a need or force propelling a possibly unwilling continued attachment to an organization, which is generally not an attractive or desirable situation. Research on personality characteristics shows us that some characteristics are considered positive or desirable (Baluch, Martin, Christian, \& Corulla, 1996; Meleddu \& Guicciardi, 1998), for example high extraversion and high agreeableness. Likewise, their opposites, low extraversion and low agreeableness, are generally considered undesirable personality characteristics. Therefore, perhaps individuals with less desirable personality characteristics may be more likely to be put in the position where they need or have to remain in their current job as a result of investments made.

Hypothesis 10: Extraversion and agreeableness will positively predict network size, relative network status, network interaction, and network relationship quality. 
Another personality characteristic of interest is work locus of control. Some studies have found either a direct or indirect relationship between locus of control and both work relationships and organizational commitment. Martin, Thomas, Charles, Epitropaki, and McNamara (2005) found a direct and positive relationship between internal locus of control and LMX, and also that the relationship between locus of control and organizational commitment was partially mediated by LMX. The authors conclude that locus of control is an important antecedent of the quality of relationships, and ultimately also of organizational commitment. Coleman, Irving, and Cooper (1999), found a significant direct relationship between locus of control and organizational commitment, with an internal locus positively associated with affective commitment and an external locus positively associated with continuance commitment. Given these findings, I hypothesize that work locus of control will relate to work relationships and have a relationship with continuance commitment mediated by work relationships.

Hypothesis 11: An internal work locus of control will positively predict network size, relative network status, network interaction, and network relationship quality.

Hypothesis 12: The relationship between work locus of control and personal sacrifice will be mediated by network size, relative network status, network interaction, and network relationship quality.

Job satisfaction. The relationship between job satisfaction and organizational commitment is well-established. In their meta-analysis on organizational commitment, Mathieu and Zajac (1990) found a strong, positive relationship between these two constructs both in terms 
of overall job satisfaction as well as all facets for both attitudinal commitment (similar to Meyer and Allen's affective commitment) and calculative commitment (similar to Meyer and Allen's continuance commitment). They also found commitment type to moderate the relationship for overall satisfaction as well as satisfaction with supervision, promotion and the work itself.

Meyer et al.’s (2002) updated meta-analysis found a significant relationship between organizational commitment and the facets of coworker and work satisfaction; however, contrary to Mathieu and Zajac's (1990) findings all of their average corrected correlations were negative. Both studies classified job satisfaction as a correlate of organizational commitment; yet, Mathieu and Zajac note that this is because the direction of causality is not clear. Rusbult's (1980) investment model conceptualizes overall job satisfaction as an input, or antecedent, to organizational commitment. As this is the model being tested in this study and Rusbult's conceptualization is not contradictory to Mathieu and Zajac's (1990) nor Meyer et al.’s (2002) view, this is the conceptualization that will be used in this study. However, although Rusbult hypothesized and found a positive relationship, in this study the direction of this relationship will not be specified as existing research has found inconsistent results.

Hypothesis 13: Job satisfaction will predict personal sacrifice.

Demographic characteristics. Support is fairly widespread for the relationship between certain demographic characteristics and organizational commitment. Age (Mathieu \& Zajac, 1990; Meyer et al., 2002; Welsch \& LaVan, 1981), education (Mathieu \& Zajac, 1990; Meyer et al., 2002), position tenure (Mathieu \& Zajac, 1990; Meyer et al., 2002), and organizational tenure (Meyer et al., 2002) have all been found to have significant relationships with 
organizational commitment. In their meta-analysis of organizational commitment, Mathieu and Zajac (1990) found significant relationships between what they called calculative commitment and several demographic characteristics: age, education and position tenure. They also found a significant relationship between calculative commitment and overall job satisfaction. Meyer et al.'s (2002) later meta-analysis on organizational commitment supports Mathieu and Zajac’s findings with respect to age, education, position tenure, overall job satisfaction, and work satisfaction, and found an additional relationship with organizational tenure.

A significant relationship between the number of hours worked per week and organizational commitment was found by Blair-Loy and Wharton (2004) as well as Jex and Bliese (1999). Part-time and full-time workers showed significantly different continuance commitment in Gakovic and Tetrick’s 2003 study, and Peters, Jackofsky, and Salter (1981) found a stronger relationship between turnover antecedents and turnover among full-time workers than part-time workers. This finding led them to conclude that full-time and part-time workers do not make withdrawal decisions on the same basis, which is relevant to this study because organizational commitment is conceptualized as an antecedent to turnover. Finally, Lynn, Cao, and Horn (1996) found support for the relationship between career stage and organizational commitment.

Relationships between demographic characteristics and work relationships have also been noted. In his study of the role of job longevity as a factor in determining job satisfaction, Katz (1978) concludes that over time (i.e., as job tenure and organizational tenure increase), employees are more likely to define their job situation more in terms of good interpersonal and supervisory relationships. Gersick, Bartunek, and Dutton (2000) found gender differences in workplace relationships, and Ibarra (1993) discusses how social networks differ on the basis of 
gender. Finally, in their study of organizational centrality (i.e., the extent to which an employee is integrated into the network of interpersonal relationships in the work system), O’Hara, Beehr, and Colarelli (1994) found that centrality was related to the respondent's hierarchical level.

The next section will review the methodology for this study. 


\section{METHOD}

\section{Participants}

A total of 1354 potential participants were invited to participate. The online survey collection program registered 518 attempts to complete the survey, and of those 470 (34.7\%) attempts were deemed completed, valid surveys. These individuals comprised the final sample. Forty eight surveys were eliminated because either all or a substantial portion of the survey was left blank, the same respondent appeared to complete the survey more than once, or the pattern of responses indicated that the respondent did not take the survey seriously (e.g., same response provided for all items, scattered responses throughout survey, same initials used to describe all work contacts). Of the completed surveys, 449 were completed online and 21 were completed via paper-and-pencil.

In order to participate in the study, participants must have been employed with their organization for at least six months and at least 18 years of age. The organizational tenure requirement was necessary because employees with shorter organizational tenure may not have had sufficient time to develop meaningful relationships with other employees, a crucial component of this study. The time period of six months was chosen on the basis of existing research (e.g., Greenberg, 2002; Katz, 1978), which found six months to be a meaningful interval in the work socialization process.

Participants were employed in six different organizations, all located in the Midwest United States. See Table 1 for detailed information on each participating organization. Five additional organizations, a Fortune 500 retailer, a non-profit social service organization, a national chain restaurant, a law firm, and a commercial real estate company were also approached to participate in this study. However, they each declined to participate. The Fortune 
500 retailer had an extensive approval process with only a small chance of ultimately gaining approval, the non-profit social service organization and the commercial real estate company were in the process of or about to conduct an employee attitude survey, the law firm was in the process of conducting an employee diversity survey and did not have the resources to focus on a second survey, and the national chain restaurant did not provide an explanation. The only noticeable difference between the organizations that did and did not choose to participate in this study is that several of the non-participants were already engaging in employee survey research and none of the participants were doing so.

The final sample was comprised of $64.3 \%$ females $(n=297)$ and $35.7 \%$ males $(n=165)$; eight individuals did not report their gender. Age of participants ranged from 18 to 71 ( $M=$ 42.79, $S D=10.90$ ); nine individuals did not report their age. Participants also reported their highest level of education received: $17.0 \%$ had a graduate degree, $21.3 \%$ had an undergraduate degree, 25.6\% had an associate or technical degree, 35.6\% had a high school degree, and $0.4 \%$ had a grade school degree. Six participants did not reporting their education level. Most participants were Caucasian $(84.6 \%, \mathrm{n}=390)$, followed by African American/Black $(9.5 \%, \mathrm{n}=$ 44), Hispanic/Latino (2.4\%, $n=11)$, Asian/Pacific Islander $(1.1 \%, n=5)$, and Native American $(0.7 \%, \mathrm{n}=3)$, with a small proportion reporting other $(1.7 \%, \mathrm{n}=8)$. Nine participants did not reporting their race.

Slightly over a third of participants reported having supervisory responsibilities (37.4\%, $\mathrm{n}$ = 176), and most participants were employed full-time $(85.9 \%, \mathrm{n}=395)$ with the remaining participants employed part-time $(14.1 \%, \mathrm{n}=65)$; 10 participants did not report their employment status. Regarding work-related contact with individuals not employed by their organization, 42.5\% ( $\mathrm{n}=198)$ of participants indicated that they did have such contact, and 57.5\% reported 
that they did not $(n=268)$; four participants did not respond to this question. When asked to rank their position within their organization on a scale of 1 to 5 ( 1 = lowest, $5=$ highest), participants reported a mean position of 3.02 and a standard deviation of 0.96 .

The median tenure with the organization was 117.0 months $(M=146.92, S D=103.92)$ and ranged from 7 to 406 months (0.58 to 33.83 years). The median job tenure was 71.5 months $(M=91.85, S D=76.46)$ and ranged from 2 to 372 months $(0.17$ to 31.00 years $)$. In terms of average number of hours worked per week, $0.2 \%$ of participants reported working 1-10 hours per week $(n=1), 1.3 \%$ reported working $11-20$ hours per week $(n=6), 4.1 \%$ reported working 2130 hours per week $(n=19), 47.5 \%$ reported working $31-40$ hours per week $(n=219), 39.5 \%$ reported working 41-50 hours per week $(\mathrm{n}=182)$, 5.9\% reported working 51-60 hours per week ( $n=27)$, and $1.5 \%$ reported working more than 60 hours per week $(n=7)$. Nine participants did not report their average number of hours worked per week.

\section{Design and Procedure}

Participants were recruited from six organizations that provided prior authorization for their employees to be invited to participate in this study. Potential participants received an e-mail from either their Human Resources department or another organizational leader that described the purpose and requirements of the study and invited recipients to learn more about and participate in the study by visiting the Internet address of the study (see Appendix A for the invitation email). Participants were informed that they had two weeks from the time the invitation e-mail was distributed to complete the survey. Approximately seven days after receiving the initial invitation e-mail, all employees, regardless of whether they had already participated in the study, received a follow-up reminder e-mail that encouraged them to participate if they had not already done so; they were given another seven days to complete the 
survey. A final e-mail reminder was sent the day before the data collection was to be completed.

See Appendix B for the reminder e-mails. Data collection was conducted from February through June.

Participation entailed answering the majority of the questions on the survey and submitting their responses by clicking on a "submit" button at the end of the survey. Potential participants were encouraged to participate through the use of a monetary incentive (i.e., participants were given the opportunity to enter a raffle in which they had the chance to win a $\$ 300$ cash prize). Also, at the end of the specified two week period, participants were given the opportunity to be e-mailed a debriefing form that described the purpose of the study in greater detail and provided contact information for the primary researcher if they had further questions. If they desired to participate in the raffle, have the debriefing form e-mailed, or both, participants were required to provide an e-mail address as a means of contact. Two check boxes corresponding to the raffle and debriefing form, respectively, were provided, and participants were required to select the check boxes that applied to the actions they desired. Providing an email address without selecting any check boxes resulted in no actions being taken.

At the end of the specified two week period for each organization, the debriefing form was mailed to participants from that organization that requested it. It is preferable to debrief participants immediately following participation. However, due to the fact that the potential participants were employed with the same organization, study integrity may have been compromised if the debriefing form was made available while the study was still fielding. For those participants that desired the debriefing information but did not wish to provide a means a contact, the address of a website with the same debriefing information was provided at the end of the survey, and the website was made available immediately following the study. 
Approximately 70 employees in organization 4 did not have access to e-mail at work. As a result, these employees were provided with a paper-and-pencil version of the survey to complete. These employees were also provided with the website address of the survey should they have preferred to complete it online. The paper-and-pencil surveys were delivered to these employees by the primary researcher on the same day that the rest of the employees received the invitation to participate via e-mail. Each survey was accompanied by a pre-addressed stamped envelope to allow for the survey to be completed and returned anonymously. Paper-and-pencil participants were allowed to provide either an e-mail address or a telephone number as a means of contact for the raffle, and an e-mail address for purposes of e-mailing the debriefing information following the study. To accommodate participants without access to e-mail, each survey packet was also accompanied by a take-away page with the website of the debriefing information that participants could access at their convenience.

Social network analysis. The focus of social network analysis is examining the relationships between social entities in a network (Wasserman \& Faust, 1994). Although some social network studies attempt to study the full social structure of a population, also known as a complete network, this study used a form of social network analysis that focuses on the respondent's egocentric network, which is an individual's unique set of social contacts (Morrison, 2002; Scott, 2000). This approach is useful for understanding how a person's unique web of contacts relates to variables at the individual level of analysis. This analysis required participants to identify various individuals with whom they have work-related contact using initials. 


\section{Materials}

All study materials were posted on an Internet website. The instructions contained an explanation of the study, the goals of the study, potential benefits to participants, a description of the monetary incentive, requirements to participate in the study, an informed consent section, contact information for the researchers, and instructions for submitting responses. See Appendix C for the complete survey instrument.

Social network. This portion of the study's methodology was modeled after Morrison (2002). Using initials, participants were asked to identify several categories of individuals. They were asked to identify their primary supervisor, up to eight coworkers ("individuals you work with most often at work, that you do not report to nor do they report to you”), up to eight subordinates, if applicable ("individuals that report to you"), up to eight individuals that they consider to be friends ("people you consider to be friends, that is, people whom you might choose to see socially outside of work or when you are not working together"), and up to eight work associates, if applicable (“individuals you work with but are not employed by your organization, e.g., clients, suppliers, vendors”). Only participants identifying themselves as a supervisor in a previous question were asked to name their subordinates, and only participants reporting that they have work-related contact with individuals not employed by their organization in a previous question were asked to name their work associates. When selecting individuals for the coworker, subordinate, and work associate categories, participants were instructed to select the individuals with whom they interact most often as the sole criteria. The number eight was chosen for the coworker, subordinate, friend, and work associate categories on the basis of Morrison's pre-testing, which indicated eight was a sufficient number of selections. 
For each individual identified, participants were asked to report the average frequency with which they interact with that individual on a 5-point scale (daily, a few times a week, 3-5 times a month, once or twice a month, less than once a month), and the quality of their work relationship with that individual on a 5-point scale (outstanding, very good, good, fair, poor). Additionally, for the individuals identified as coworkers or friends, participants were asked to report that individual's hierarchical level relative to their own level on a 3-point scale (lower level than myself, about the same level as myself, higher level than myself) and for the individuals identified as friends participants were asked to report the closeness of their relationship on a 3-point scale (not very close, reasonably close, very close). Finally, for the individuals listed in the subordinate, coworker, friend, and work associate categories, participants were asked to report if they had listed the same person in a previous category (yes or no).

Organizational commitment. Participants were asked to complete Meyer and Allen’s (1991, 1997) revised organizational commitment measure. This measure consists of three scales: continuance ( $\alpha=.71)$, affective $(\alpha=.79)$, and normative $(\alpha=.85)$. Each scale has six items and ratings were made on a 7-point scale ( 1 = Strongly Disagree, $7=$ Strongly Agree). An example item is "Right now, staying with my organization is a matter of necessity as much as desire." Workplace friendship opportunity. Workplace friendships will be measured as a construct using Nielsen, Jex and Adam’s (2000) scale using the friendship opportunity subscale. It has six items $(\alpha=.80)$, and responses were made on a 5-point scale $(1=$ Strongly Disagree, 5 = Strongly Agree).

Other work investments. Participants were asked to assume that they are thinking about leaving their current job. Under that scenario, they were asked to report on a 5-point scale how 
likely $(1=$ Not at all Likely, $5=$ Extremely Likely $)$ each of 13 work characteristics $(\alpha=.84)$ would be to keep them from leaving their job. Sample items include "Amount of vacation time" and "Seniority."

Four items assessing job alternatives were also included on the same scale ( $\alpha=.82)$, with “Attractiveness of other job opportunities” as a sample item.

Job satisfaction. Participants were asked to complete the Abridged Job in General (AJIG; Russell, Spitzmueller, Lin, Stanton, \& Smith, 2002) consisting of eight items ( $\alpha=.81)$. The items are adjectives or short phrases, and using a Yes, No, or ? response scale participants were asked to indicate if each adjective/phrase described their job. An example item is "Enjoyable.” Intentions to quit. Participants were asked to report their intentions to quit their current job using the Intentions to Quit Scale (ITQ; Crossley, Lin, \& Stanton, 2002). This scale consists of 6 items $(\alpha=.92)$ and was measured using a 7-point scale $(1=$ Strongly Disagree, $7=$ Strongly Agree).

Personality. Need for affiliation was measured using Hill’s (1987) affiliation motivation scale. It consists of 15 items which cover two of its four subscales: emotional support (6 items; $\alpha$ $=.90$ ) and positive stimulation (9 items; $\alpha=.89$ ). All items were measured on a 5-point scale (1 $=$ Not at all true, 5 = Completely True). An example item is "I usually have the greatest need to have other people around me when I feel upset about something.”

Two of the "Big Five” personality traits, extraversion $(\alpha=.81)$ and agreeableness $(\alpha=$ .85), were assessed using the shortened version of Goldberg’s Mini-Markers (Saucier, 1994), in which participants were asked to describe themselves using 16 adjectives each with a 9-point scale (1 = Extremely Inaccurate, 9 = Extremely Accurate). Sample adjectives include “Cooperative” and “Talkative.” 
Work locus of control was measured using Spector's Work Locus of Control Scale (WLCS; Spector, 1988), which consists of 16 items $(\alpha=.84)$ each with a 6-point scale $(1=$ Disagree very much, 6 = Agree very much). Items suggestive of an external work locus of control (e.g., "Getting the job you want is mostly a matter of luck”) were reverse-scored; therefore, higher numbers indicate an internal work locus of control.

Demographic characteristics. Participants were asked to report their gender (i.e., male, female), age (in years), highest level of education completed (i.e., graduate degree, undergraduate degree, associate/technical degree, high school, grade school), length of organizational tenure (in months), length of position tenure (in months), the level of their position within their organization on a scale of 1 to $5(1=$ lowest, $5=$ highest $)$, if they have regular work-related interactions with individuals not employed by the organization (i.e., work associates; yes or no), and if they supervise anyone (yes or no). Participants will also be asked to report their employment status (i.e., full-time, part-time) and the average number of hours that they work each week (i.e., 0-10, 11-20, 21-30, 31-40, 41-50, 51-60, More than 60). Finally, participants from organizations 1, 4, 5, and 6 were asked to report various identifying characteristics of their position specific to their organization, such as the division of the organization in which they are employed or the type of position they hold. These questions were included to be able to provide the participating organizations with more detailed and actionable feedback on their employees; therefore, the findings for these questions will not be reported here. 


\section{RESULTS}

\section{Descriptives}

Work constructs. Table 2 includes the means, standard deviations and Pearson product moment intercorrelations for the variables under consideration. On a scale of 1 to 7 , continuance commitment had a mean of $4.09(S D=1.15)$, with higher numbers indicating higher continuance commitment. The alternatives subscale of continuance commitment had a mean of $4.15(S D=$ 1.39), and the personal sacrifice subscale had a mean of $4.02(S D=1.31)$. These findings indicate that collectively, respondents reported an average level of continuance commitment with a range of individual attitudes. Also on scales of 1 to 7 , affective commitment had a mean of $4.70(S D=1.24)$ and normative commitment had a mean of $4.30(S D=1.37)$.

On a scale of 1 to 7 with higher numbers indicating a greater intent, intent to quit had a mean of $2.69(S D=1.52)$. The Job-in-General scale, using a scale of 0 to 3 with higher numbers indicating greater job satisfaction, had a mean of $2.39(S D=.70)$. Participants in general indicated that they had good opportunities to make friends at work, as shown by a mean of 3.94 $(\mathrm{SD}=.59)$ on a scale of 1 to 5 . These findings denote that participants are generally satisfied with their jobs, have opportunities to make friends at work, and have a low intent to quit their jobs. Two other constructs, other work investments and work alternatives, were also assessed. On a scale of 0 to 6 , with 0 indicating a lack of access to or use of a particular investment or alternative characteristic, other work investments had a mean of $2.80(S D=.94)$ and work alternatives had a mean of $2.43(S D=1.24)$.

Personality. Several personality characteristics were also measured in this study, with higher numbers indicating more of the indicated trait. Need for affiliation, measured on a 1 to 5 scale, had a mean of $2.72(S D=.85)$. Extraversion, measured on a 1 to 9 scale, had a mean of 
$6.06(S D=1.32)$. Agreeableness, also measured on a 1 to 9 scale, had a mean of $7.28(S D=$ 1.08). Finally, work locus of control, measured on a 1 to 6 scale, had a mean of $4.49(S D=.65)$. Social network. Social network findings were calculated at both the overall network level and also by network category (i.e., primary supervisor, coworker, subordinate, friend, work associate). Looking at each participant's overall social network, out of a possible 33 unique individuals the mean number listed is $12.71(S D=5.48)$. On a scale of 1 to 5 , the mean work relationship quality is $3.71(S D=.57)$ and the mean network interaction is $4.17(S D=.62)$. On a scale of 1 to 3 , the mean relative network status is $2.02(S D=.39)$. On a scale of 1 to 3 , the mean friendship intimacy is $2.11(S D=.45)$.

Distribution properties. Some of the key variables in this study showed signs of skewness in their distribution, indicated by skewness greater than or equal to two times the standard error of skewness (Tabachnick \& Fidell, 1996). Intentions to quit, measured on a scale of 1 to 7 , had a mean of only 2.69 and skewness of 0.86 (Standard Error of Skewness $=0.11$ ), indicating positive skew. Network size also showed positive skew, with a mean of only 12.71 on a scale of 0 to 33 and skewness of 0.58 (Standard Error of Skewness $=0.11$ ). Several variables also showed signs of negative skew. Other work investments had a mean of 2.80 on a scale of 1 to 5 and skewness of -.25 (Standard Error of Skewness = 0.11), friendship opportunity had a mean of 3.94 on a scale of 1 to 5 and skewness of -0.51 (Standard Error of Skewness $=0.11$ ), agreeableness had a mean of 7.28 on a scale of 1 to 9 and skewness of -0.98 (Standard Error of Skewness $=0.11$ ), and job satisfaction had a mean of 2.39 on a scale of 0 to 3 and skewness of -1.42 (Standard Error of Skewness $=0.11$.

Range restriction was noticeable among several variables as well. Although the possible scale range for agreeableness was 1 to 9 , the actual composite range was 2.7 to 9 . Work locus of 
control showed a similar pattern (scale range $=1$ to 6 , actual composite range $=2.6$ to 5.9 ) as did network size (scale range $=0$ to 33, actual composite range $=0$ to 29). Extraversion (scale range $=1$ to 9 , actual composite range $=1.6$ to 9 ) and workplace friendship opportunity (scale range = 1 to 5 , actual composite range $=1.5$ to 5 ) also had this pattern, although to a lesser extent. Although range restriction can attenuate correlations, the restrictions found here do not seem sufficiently severe to have a meaningful impact.

\section{Correlations}

Table 2 reports correlations between all continuous and dichotomous variables. Correlations relevant to the hypotheses examined in this study are discussed below.

Continuance commitment - personal sacrifice. Personal sacrifice was significantly correlated $(p<.05)$ with intent to quit $(r=-.23)$, other work investments $(r=.19)$, friendship opportunity $(r=.11)$, need for affiliation $(r=.13)$, work locus of control $(r=-.11)$, network size ( $r$ $=.13$ ), and relative network status $(r=-.10)$. It was not significantly correlated with job satisfaction, work alternatives, network relationship quality, network interaction, friendship intimacy, gender, or job level ( $p>.05)$.

Intent to quit. Intent to quit was significantly correlated $(p<.05)$ with personal sacrifice ( $r=-.23)$, job satisfaction $(r=-.53)$, friendship opportunity $(r=-.34)$, need for affiliation ( $r=-$ $.12)$, work alternatives ( $r=.13$ ), work locus of control $(r=-.21)$, network relationship quality $(r$ $=-.21)$, network size $(r=-.11)$, gender $(r=-.10)$, and job level $(r=-.17)$. It was not significantly correlated with other work investments, network interaction, relative network status, or friendship intimacy $(p>.05)$.

Social network. Network relationship quality was significantly correlated with friendship opportunity $(r=.36)$, need for affiliation $(r=.10)$, work locus of control $(r=.15)$, extraversion 
$(r=.20)$, and agreeableness $(r=.28)$. Network size was significantly correlated with need for affiliation $(r=.17)$, work locus of control $(r=.17)$, extraversion $(r=.21)$, and agreeableness $(r=$ .14). Network interaction was significantly correlated with work locus of control $(r=-.13)$ and agreeableness $(r=-.10)$. Other than the correlation between relative network status and personal sacrifice mentioned above, relative network status and friendship intimacy did not have any significant correlations with relevant variables $(p>.05)$.

\section{Regression Analyses}

Where hypotheses stated a relationship between continuance commitment and other variables, the personal sacrifice subscale (hereafter referred to simply as personal sacrifice) was used. All moderation and mediation tests were conducted according to the procedures outlined in Baron and Kenny (1986).

Before conducting the regression analyses, the correlations between the work relationship variables and the two dependent variables, personal sacrifice and intentions to quit, as well as other variables that they were hypothesized to correlate with were inspected. Of the four work relationship variables, only network size and relative network status correlated significantly with the personal sacrifice, $p<.05$. Only network size and network relationship quality correlated significantly with intentions to quit, $p<.05$. Due to these findings, for each hypothesis where personal sacrifice was the dependent variable, only network size and relative network status were used as the work relationship constructs. For each hypothesis where intentions to quit was the dependent variable, only network size and network relationship quality were used as the work relationship constructs. Where work relationship constructs were hypothesized to either predict or be predicted by other variables, regression analyses were only conducted if the correlations between those variables were significant, $p<.05$. 
Hypothesis 1. Hypothesis 1 predicted that the investment model applied to work relationships would be supported. Network size and relative network status were the work relationship variables used in this analysis. Job satisfaction, job alternatives, and other work investments were entered as the first block in the regression equation and network size and relative network status were entered as the second block. In the first block, these three characteristics accounted for $6 \%$ of the variance in personal sacrifice $\left(R^{2}=.06\right.$; Adjusted $R^{2}=$ $.05 ; F(3,463)=8.95, p<.05)$. The standardized beta coefficients for work alternatives and other work investments were significant $(p<.05)$. Network size and relative network status were entered as the second block and accounted for an additional 1\% of the variance in personal sacrifice. The standardized beta coefficient for network size was also significant $(p<.05)$. Therefore, hypothesis 1 was partially supported. See Table 4 for the complete results of this analysis.

Hypothesis 2. Hypothesis 2 predicted that work relationships combined with other work investments would predict personal sacrifice better than other work investments alone. Network size and relative network status were the work relationship variables used in this analysis. Other work investments was entered as the first block in the regression equation and network size and relative network status were entered as the second block. In the first block, other work investments accounted for $4 \%$ of the variance in personal sacrifice $\left(R^{2}=.04\right.$; Adjusted $R^{2}=.04$; $F(1,465)=19.18, p<.05)$. The standardized beta coefficient for other work investments was significant $(p<.05)$. Network size and relative network status were entered as the second block and accounted for an additional $2 \%$ of the variance in personal sacrifice. The standardized beta coefficient for network size was also significant $(p<.05)$. Therefore, hypothesis 2 was partially supported. See Table 5 for the complete results of this analysis. 
Hypothesis 3. Hypothesis 3 predicted that work relationships combined with personal sacrifice would predict intentions to quit better than personal sacrifice alone. Network size and network relationship quality were the work relationship variables used in this analysis. Personal sacrifice was entered as the first block in the regression equation and both network size and network relationship quality were entered as the second block. In the first block, personal sacrifice accounted for $6 \%$ of the variance in intentions to quit $\left(R^{2}=.06\right.$; Adjusted $R^{2}=.05 ; F(1$, $467)=27.81, p<.05)$. The standardized beta coefficient for personal sacrifice was significant $(p$ $<.05)$. Network size and network relationship quality were entered as the second block and accounted for an additional $4 \%$ of the variance in intentions to quit. The standardized beta coefficient for network relationship quality was significant $(p<.05)$. Therefore, hypothesis 3 was partially supported. See Table 6 for the complete results of this analysis.

Hypothesis 4. Hypothesis 4 predicted that network size would positively predict the size of the personal sacrifice associated with leaving one’s job. Network size did correlate positively and significantly with personal sacrifice $(r=.13, p<.05)$, and also significantly predicted personal sacrifice $\left(R^{2}=.02 ;\right.$ Adjusted $\left.R^{2}=.02 ; F(1,468)=8.36, p<.05\right)$. Therefore, hypothesis 4 was supported. See Table 7 for the complete results of this analysis.

Hypothesis 5. Hypothesis 5 predicted that relative network status would positively predict the size of the personal sacrifice associated with leaving one's job. Relative network status did correlate significantly with personal sacrifice, although negatively $(r=-.10, p<.05)$, and also significantly predicted personal sacrifice $\left(R^{2}=.01\right.$; Adjusted $\left.R^{2}=.01 ; F(1,465)=4.30, p<.05\right)$. Therefore, hypothesis 5 was partially supported. See Table 8 for the complete results of this analysis. 
Hypothesis 6. Hypothesis 6 predicted that network interaction would positively predict the size of the personal sacrifice associated with leaving one's job. Network interaction did not correlate significantly with personal sacrifice nor did it significantly predict personal sacrifice, $p$ $>$.05. Therefore, hypothesis 6 was not supported. See Table 9 for the complete results of this analysis.

Hypothesis 7. Hypothesis 7 predicted that network relationship quality would positively predict the size of the personal sacrifice associated with leaving one's job. Network relationship quality did not correlate significantly with personal sacrifice nor did it significantly predict personal sacrifice, $p>.05$. Therefore, hypothesis 7 was not supported. See Table 10 for the complete results of this analysis.

Hypothesis 8 . Hypothesis 8 predicted that need for affiliation would moderate the relationship between work relationships and personal sacrifice. Network size and relative network status were the work relationship variables used in this analysis, and were tested separately. Moderation was tested in accordance with Baron and Kenny (1986).

Network size was entered as the first block in the regression equation, need for affiliation was entered as the second block, and the interaction between network size and need for affiliation was entered as the third block. In the first block, network size accounted for $2 \%$ of the variance in personal sacrifice $\left(R^{2}=.02 ;\right.$ Adjusted $\left.R^{2}=.02 ; F(1,468)=8.36, p<.05\right)$. The standardized beta coefficient for network size was significant $(p<.05)$. Need for affiliation was entered as the second block and accounted for an additional 1\% of the variance in personal sacrifice. The standardized beta coefficient for need for affiliation was significant $(p<.05)$. Finally, the interaction between network size and need for affiliation was entered as the third block. The interaction was not significant and no additional variance was accounted for by this 
block, indicating that there was no moderation. See Table 11 for the complete results of this analysis.

Relative network status was entered as the first block in the regression equation, need for affiliation was entered as the second block, and the interaction between relative network status and need for affiliation was entered as the third block. In the first block, relative network status accounted for $1 \%$ of the variance in personal sacrifice $\left(R^{2}=.01\right.$; Adjusted $R^{2}=.01 ; F(1,465)=$ 4.30, $p<.05$ ). The standardized beta coefficient for relative network status was significant ( $p<$ .05). Need for affiliation was entered as the second block and accounted for an additional $2 \%$ of the variance in personal sacrifice. The standardized beta coefficient for need for affiliation was significant $(p<.05)$. Finally, the interaction between relative network status and need for affiliation was entered as the third block. The interaction was not significant and no additional variance was accounted for by this block, indicating that there was no moderation. Therefore, hypothesis 8 was not supported. See Table 12 for the complete results of this analysis.

Hypothesis 9. Hypothesis 9 predicted that workplace friendship opportunity would moderate the relationship between work relationships and personal sacrifice. Network size and relative network status were the work relationship variables used in this analysis, and were tested separately. Moderation was tested in accordance with Baron and Kenny (1986).

Network size was entered as the first block in the regression equation, workplace friendship opportunity was entered as the second block, and the interaction between network size and workplace friendship opportunity was entered as the third block. In the first block, network size accounted for $2 \%$ of the variance in personal sacrifice $\left(R^{2}=.02\right.$; Adjusted $R^{2}=.02 ; F(1,468)$ $=8.36, p<.05)$. The standardized beta coefficient for network size was significant $(p<.05)$. Workplace friendship opportunity was entered as the second block and accounted for an 
additional $1 \%$ of the variance in personal sacrifice. The standardized beta coefficient for workplace friendship opportunity was significant $(p<.05)$. Finally, the interaction between network size and workplace friendship opportunity was entered as the third block. The interaction was not significant and no additional variance was accounted for by this block, indicating that there was no moderation. See Table 13 for the complete results of this analysis.

Relative network status was entered as the first block in the regression equation, workplace friendship opportunity was entered as the second block, and the interaction between relative network status and workplace friendship opportunity was entered as the third block. In the first block, relative network status accounted for $1 \%$ of the variance in personal sacrifice $\left(R^{2}\right.$ $=.01$; Adjusted $\left.R^{2}=.01 ; F(1,465)=4.30, p<.05\right)$. The standardized beta coefficient for relative network status was significant $(p<.05)$. Workplace friendship opportunity was entered as the second block and accounted for an additional $1 \%$ of the variance in personal sacrifice. The standardized beta coefficient for workplace friendship opportunity was significant $(p<.05)$. Finally, the interaction between relative network status and workplace friendship opportunity was entered as the third block. The interaction was not significant and no additional variance was accounted for by this block, indicating that there was no moderation. Therefore, hypothesis 9 was not supported. See Table 14 for the complete results of this analysis.

Hypothesis 10. Hypothesis 10 predicted that extraversion and agreeableness would positively predict work relationships. Each work relationship construct served as a separate dependent variable in a series of regression equations, with the characteristics that had significant correlations with that construct entered as predictors.

Both extraversion and agreeableness correlated significantly with network relationship quality $(r=.20, r=.28$, respectively, $p<.05)$, and were therefore entered into the regression 
equation. Collectively, they account for $10 \%$ of the variance in network relationship quality $\left(R^{2}=\right.$ .10 ; Adjusted $\left.R^{2}=.10 ; F(2,466)=26.76, p<.05\right)$ and the standardized beta coefficients for both predictors were also significant, $p<.05$.

Both extraversion and agreeableness correlated significantly with network size $(r=.21, r$ $=.14$, respectively, $p<.05$ ), and were therefore entered into the regression equation. Collectively, they account for $6 \%$ of the variance in network size $\left(R^{2}=.06\right.$; Adjusted $R^{2}=.05$; $F(2,467)=13.47, p<.05)$ and the standardized beta coefficients for both predictors were also significant, $p<.05$.

Only agreeableness correlated significantly with network interaction $(r=.10, p<.05)$, and was therefore entered in the regression equation. Agreeableness accounted for $1 \%$ of the variance in network interaction $\left(R^{2}=.01\right.$; Adjusted $\left.R^{2}=.01 ; F(1,467)=4.91, p<.05\right)$ and the standardized beta coefficient was also significant, $p<.05$.

Neither extraversion nor agreeableness correlated significantly with relative network status $(p>.05)$, and therefore no regression tests were performed.

Given that either extraversion, agreeableness, or both predict three of the four work relationship constructs, hypothesis 10 is partially supported. See Table 15 for the complete results of this analysis.

Hypothesis 11 . Hypothesis 11 predicted that work locus of control would positively predict work relationships. Each work relationship construct that had a significant correlation with work locus of control served as a separate dependent variable in a series of regression equations with work locus of control entered as the predictor. Work locus of control correlated significantly with network relationship quality $(r=.15)$, network size $(r=.17)$, and network 
interaction ( $r=.13), p<.05$. It did not correlate significantly with relative network status; therefore, that regression equation was not tested.

Work locus of control accounts for $2 \%$ of the variance in network relationship quality $\left(R^{2}\right.$ $=.02 ;$ Adjusted $\left.R^{2}=.02 ; F(1,467)=10.85, p<.05\right)$, and its standardized beta coefficient was also significant, $p<.05$. Regarding network size, work locus of control accounts for $3 \%$ of the variance $\left(R^{2}=.03 ;\right.$ Adjusted $\left.R^{2}=.03 ; F(1,468)=13.79, p<.05\right)$, and its standardized beta coefficient was also significant, $p<.05$. Finally, regarding network interaction work locus of control accounts for $2 \%$ of the variance $\left(R^{2}=.02\right.$; Adjusted $\left.R^{2}=.02 ; F(1,467)=8.35, p<.05\right)$, and its standardized beta coefficient was also significant, $p<.05$.

Given that work locus of control significantly predicts three of the four work relationship constructs, hypothesis 11 is partially supported. See Table 16 for the complete results of this analysis.

Hypothesis 12. Hypothesis 12 predicted that the relationship between work locus of control and personal sacrifice would be mediated by work relationships. As two work relationship variables had significant relationships with personal sacrifice, network size and relative network status, two sets of three regression tests were conducted to test this hypothesis, in accordance with Baron and Kenny (1986).

Network size was tested first. First, network size was regressed on work locus of control, which accounted for $3 \%$ of the variance $\left(R^{2}=.03\right.$; Adjusted $\left.R^{2}=.02 ; F(1,467)=12.61, p<.05\right)$. Next, personal sacrifice was regressed on work locus of control, which accounted for $1 \%$ of the variance $\left(R^{2}=.01 ;\right.$ Adjusted $\left.R^{2}=.01 ; F(1,468)=5.23, p<.05\right)$. Finally, personal sacrifice was regressed on both work locus of control and network size, and collectively they accounted for $3 \%$ of the variance $\left(R^{2}=.03 ;\right.$ Adjusted $\left.R^{2}=.03 ; F(2,466)=6.97, p<.05\right)$. For mediation to 
occur, all three regression tests must be significant, and the effect of work locus of control on personal sacrifice must be less in the third test than in the second test. All three regression tests were significant; however, the effect of work locus of control was virtually the same in tests two and three. Therefore, there is no mediation. See Table 17 for the complete results of this analysis. Relative network status was then tested. First, relative network status was regressed on work locus of control and it was not a significant predictor, $p>.05$. As this test is required to be significant for there to be mediation and it was not, no further tests were conducted and it is concluded that there is no mediation. Therefore, hypothesis 12 is not supported.

Hypothesis 13. Hypothesis 13 predicted that job satisfaction would predict personal sacrifice. Job satisfaction did not correlate significantly with personal sacrifice nor did it significantly predict personal sacrifice, $p>.05$. Therefore, hypothesis 13 was not supported. See Table 18 for the complete results of this analysis. 


\section{DISCUSSION}

This study attempted to add greater understanding to one of the most widely studied job attitudes, organizational commitment, and one of the most significant outcomes for organizations, intentions to quit. The results support the premise of this study that work relationships do contribute additional explanation to both of these constructs. Two of the five social network constructs (i.e., network size and relative network status) were significantly correlated $(p<.05)$ with the personal sacrifice dimension of continuance commitment, and 2 of the 5 social network constructs (i.e., network relationship quality and network size) were significantly correlated $(p<.05)$ with intentions to quit. Of the 13 hypotheses, one was fully supported and six were partially supported. Table 19 summarizes the results of each hypothesis test.

Network size was the only social network construct to correlate significantly with both personal sacrifice and intentions to quit. In all cases where it was a significant predictor it predicted the outcome in a positive direction. Therefore, a larger network size does seem to predict greater investment in the organization, and therefore greater personal sacrifice. Interestingly, although network size did correlate significantly with intentions to quit and as expected its standardized beta coefficient had a negative sign, it was not a significant predictor of it as tested in hypothesis 3 . This may be a result of too much shared variance with personal sacrifice; network size had a significant relationship with personal sacrifice, which was a significant predictor in that test.

Although relative network status had a significant negative relationship with personal sacrifice, it was not a significant predictor in any regression tests. These findings suggest that perhaps relative network status only has an impact in specific types of situations or for certain 
demographics, and when it does have a significant influence that having higher status contacts tends to coincide with lower personal sacrifice. This inference contradicts the hypothesized relationship between relative network status and personal sacrifice. However, due to the nature of this construct (the status of contacts is only within the participant's control for select categories of contacts), it was limited to the coworker and friend network categories. Perhaps it is merely that the status of contacts in these categories is not influential, and the influence of status is to be found in other positions. For example, a participant may have a good relationship with a company executive but may not work directly with that person nor consider that person a friend. Therefore, losing a person of such high status might be costly, but would not have been captured in this study because that individual did not fit into any of the contact categories provided.

Network relationship quality, although arguably the social network construct of the greatest interest, only had a significant relationship with intentions to quit, not personal sacrifice. The results showed that it was a strong, negative predictor of intentions to quit, indicating that the quality of relationships does help to explain intentions to quit more so than personal sacrifice alone. It was surprising that network size predicted personal sacrifice and network relationship quality did not. Perhaps respondents believed that the size of their network may be difficult to maintain in the face of organizational withdrawal but that the quality of close relationships may be easier to preserve (e.g., via e-mail, phone, etc.). Therefore, losing high quality relationships is not viewed as a sacrifice, because they are not expected to be lost.

Network interaction was not an explanatory construct for either personal sacrifice or intentions to quit. It also did not correlate significantly with any non-relationship primary variables in the study, other than work locus of control $(r=-.13)$ and agreeableness $(r=-.10)$. 
Perhaps interaction frequency is something respondents believe to be within their control, and therefore they can recreate their desired interaction frequency at another organization. If that is the case, then it would not be a sacrifice or a reason to intend to quit (or stay). Alternatively, perhaps it is merely not a strong or relevant network construct, and therefore does not have a significant effect on attitudes and intentions.

Hypotheses 8 and 9, which purported that need for affiliation and workplace friendship opportunity would moderate the relationship between work relationships and personal sacrifice, respectively, were not supported. This is likely due to the fact that both hypothesized moderators were themselves significantly correlated $(p<.05)$ with both personal sacrifice and intentions to quit. In both cases, they had a positive relationship with personal sacrifice. This indicates that greater friendship opportunity and greater need for affiliation lead to a greater feeling of personal sacrifice in the case of withdrawal. Also in both cases, they had a negative relationship with intentions to quit. Intentions to quit seem to lessen with increased friendship opportunity and need for affiliation.

Taken together, these findings support the premise of this study and concur with Sheldon's claim that measuring both investments and social involvements is crucial to understanding organizational withdrawal. More specifically, both the quantity and quality of work relationships, operationalized by network size and network relationship quality, seem to be the most influential social network or involvement elements. Furthermore, both the internal need to associate with others as well as the external opportunity to do so positively impact the feeling of personal sacrifice and intent to continue organizational membership. 


\section{Theoretical Implications}

These results suggest some implications for theory on continuance commitment and work relationships. First, work relationships, specifically the number and quality, were demonstrated to have a significant and measurable effect on the cognitive representations of personal sacrifice and intentions to quit. Although difficult to measure quantitatively in this study, the literature supports work relationships conceptualized as investments (Miller \& Labovitz, 1973; Mitchell et al., 2001; Sheldon, 1971), which allows them to fit under the personal sacrifice domain. Doing so allows us to incorporate work relationships into the personal sacrifice dimension of continuance commitment. This action increases the explanatory power of continuance commitment and allows for better prediction of interesting and useful outcomes, such as intentions to quit. It should also be noted that job satisfaction had a strong significant positive correlation with network relationship quality $(r=.27)$, although it did not have a relationship with any other work relationship measures. This finding indicates that work relationships may have implications for other workplace attitudes and behaviors, which should be explored in future research.

Second, this study demonstrated that work relationships do correlate with and predict personal sacrifice. Correlations do not denote causality; however, in many instances only one direction of causality is probable. Although this instance is not without some ambiguity, it seems more reasonable that work relationships would cause personal sacrifice and not vice versa. A longitudinal test to determine causality could be conducted to test this theory. If this theory of causality is accurate, work relationships (i.e., network size and relative network status) will be found to be antecedents of personal sacrifice, and therefore continuance commitment. Indeed, network size in particular should be further examined because it explained variance in personal sacrifice over and above other investments. So, with further research work relationships may be 
added to the list of antecedents, not simply correlates, for continuance commitment. As previously discussed, this is important because typically the literature on antecedents of continuance commitment has focused on economical rather than personal costs incurred (Meyer et al., 2002; Meyer \& Allen, 1997). To be able to add personal costs would expand the theory into new territory and provide it with a more comprehensive scope.

Third, the investment model (Farrell \& Rusbult, 1981; Rusbult, 1980; Rusbult \& Farrell, 1983) should be used as a theoretical basis for examining continuance commitment because network size predicted continuance commitment over affect, job alternatives, and other work investments. This is important because the major theoretical justification for continuance commitment has relied on Becker's (1960) side bets theory. Support for the investment model suggests that there are other theories that deserve to be examined and could help to develop further the construct of continuance commitment.

Personality may have implications for the development of continuance commitment. Erdheim et al. (2006) found that the Big Five personality traits of extraversion and openness to experience correlated negatively with continuance commitment and neuroticism and conscientiousness correlated positively; agreeableness did not have a significant relationship with continuance commitment. Naquin and Holton (2002) also found a significant negative correlation between extraversion and continuance commitment and that agreeableness had no relationship. The present study's findings agree with both Erdheim et al. and Naquin and Holton's results, as extraversion was found to correlate negatively and agreeableness did not have a significant relationship with continuance commitment. Coleman et al.'s (1999) finding that an external work locus of control positively predicted continuance commitment was also supported here. Need for affiliation, a personality trait not previously studied in relation to 
continuance commitment, was also found to correlate with continuance commitment. Finally, other factors that may lead to continuance commitment (e.g., other work investments, network relationship quality, network size, network interaction) had significant correlations with personal sacrifice. Taken together, these findings suggest that future research examining how the personality - commitment relationship is impacted by these network factors might be fruitful.

Lastly, these findings lead to additional questions about where work relationships fit into organizational commitment. Work relationships have been demonstrated to add explanation to continuance commitment, but they could also conceivably add explanation to affective and normative commitment as well. Having good work relationships could increase an employee’s desire to remain with their organization because they want to maintain those relationships (i.e., affective commitment). It could also increase an employee's sense of obligation to his or her colleagues to remain with the organization and not let them down (i.e., normative commitment). Thus, work relationships could be incorporated into all three forms of organizational commitment. However, given their potentially extensive and unique addition to organizational commitment, another possibility is that work relationships comprise a fourth form of commitment: relational commitment. Future research examining the most appropriate incorporation of work relationships into the construct of organizational commitment would be valuable.

\section{Practical Implications}

Organizations would benefit from considering network size and relationship quality in their organizational development plans. This knowledge could be used to help organizations find ways to encourage greater commitment, and therefore lesser intentions to quit, among their employees. This study found that personality traits predict network relationship constructs, 
which in turn have implications for continuance commitment and intentions to quit. They could use this information to hire employees with personality traits that are more likely to be able to develop strong networks and become committed to the organization. To aid in developing strong networks among employees, they could run organizational development interventions such as restructuring the organizational configuration (e.g., move to a team-based configuration), which would enable employees to develop bigger and more meaningful networks. Networking seminars on relationship-building in the workplace could also be provided to aid in that effort.

Creating policies and practices that encourage employees to develop larger networks, both formally (e.g., mentoring programs, cross-functional or cross-divisional teams, shifting employees onto different projects or teams periodically allowing them to work with and get to now different employees) and informally (e.g., office parties, happy hours, retreats) would benefit organizations. Such policies and practices would be most effective if they could be incorporated into the organizational culture. During the initial socialization process, it could be stressed that the organization places value on employees being fully immersed and connected within the organization. This message would encourage new employees to create large and strong networks, thereby helping to propagate culture change. Regarding existing employees, formal memos or brochures could be distributed that will inform them of the upcoming changes to the organizational structure and nature of work and how those changes are in line with the new organizational goals. Management should show support and set an example by exemplifying the desired cultural changes, and thereby helping to integrate them from the top down. Informative training or question and answer sessions could be provided to help integrate the changes and obtain employee buy-in. 
As the quality of work relationships was shown to predict lower intentions to quit, encouraging employees to have good working relationships with their coworkers is desirable. Incorporating training sessions on how to work effectively with others, manage conflict, and communicate effectively would be beneficial.

Prior to any attempts at cultural changes, the current culture should be assessed. After implementation, the effectiveness of the change efforts should be monitored periodically using employee surveys on employee attitudes and organizational culture, as well as employee focus groups. Organizations should be accepting of and open to making changes based on the findings of these data-gathering efforts to ensure that the intended culture changes are being effectively incorporated. Follow-up comparisons of the current state as compared to the baseline will help organizations understand the progress made and how much more effort should be put forth.

\section{Limitations}

One limitation of this study is that to obtain enough responses to conduct the desired analyses, six different organizations were recruited to participate. They were located in different geographic areas (e.g., different states in the Midwestern United States), operate in different industries (e.g., retail, educational, governmental) and have a wide variety of employee types (e.g., full-time, part-time, blue collar, white collar). Having such a mixture of organizations precludes us from drawing specific conclusions that would apply to a particular industry, geographic location, or employee type. However, the cross-sectional nature of the study does allow us to draw some general conclusions that likely do apply to many different organizations and employees, which is beneficial. That many significant results were found in this study in spite of the sample's diversity in fact provides more evidence that these results are generalizable; 
it may indicate that these findings reflect common work relationship trends that hold true across a wide variety of organizations, geographical areas, and employee types.

The structural differences between the six participating organization represent another limitation. In particular, whether each participating organization was flat or hierarchical in structure could have affected the work relationship variables, specifically relative network status. The larger participating organizations (i.e., organizations 1, 5, and 6) were more hierarchical, while the smaller organizations (i.e., organizations 2, 3, and 4) were more flat. Flat organizations would have little variation in contact status, whereas hierarchical organizations would have a great deal of variation. Structural dissimilarities between the organizations could have muddled the findings or subdued the effects. Future research should consider organizational structure as a factor in choosing participating organizations and analyzing the results.

Another limitation is because actual names of network contacts were not captured, it was not possible to do an analysis of each person's social network in combination with others in their network. It was believed that potential participants would have found this type of data collection more intrusive, which may have led to less open and honest responses. Fortunately, this level of data was not required to answer this study's research questions. However, given the richness of the data that would have been obtained, it would have been advantageous to have it available for future analyses or research studies.

A further limitation is that the types of network contacts elicited in this study may not have been fully comprehensive. As mentioned earlier, a participant may have relationships with individuals that did not fit into the given categories, such as a company executive who by definition would not fit in either the supervisor, subordinate, or work associate categories, but the participant does not work with this individual directly (and therefore would not fit into the 
coworker category) nor is the individual a friend (and therefore would not fit into the friend category). Not fully capturing the network of participants may have limited the knowledge gained from the results or at the least prevented us from learning everything possible about the effect of work social networks on continuance commitment and intentions to quit.

Finally, due to geographic and practical constraints, the data collection process was not completely consistent across organizations. At organizations 3, 5, and 6 not all participants had personal computer access. As a result, many of them participated via common computers set up in their workplace as opposed to a personal computer. These common computers were intended to be located in secluded places that would provide participants with some privacy, but due to their very nature they were in public areas. Not having complete privacy while completing the survey may have impacted potential participant's comfort with participating as well as providing open and honest responses.

At organization 4, not all participants had personal computer access but common computers were not an option due to the geographic dispersion of employees; therefore, some participants participated via paper instead of the Internet. Although studies on paper-and-pencil versus web-based data collection tend to yield no differences between the methodologies, (Stanton and Rogelberg [2001] found in their survey of seven different primary studies that no substantive differences were found in the conclusions drawn from web-based versus paper-andpencil data collection techniques), it is possible that the two methodologies affected the results. Only 21 of the 470 responses in the final data were collected via paper-and pencil, so any differences that may have resulted would have had only a small effect on the total results.

In organizations where all potential participants had personal computer access, reminders were sent only via e-mail. However, at organizations where not all employees had personal 
computer access, reminders were provided via a combination of e-mail, paper flyers, and inperson from managers. All efforts were made to keep the methods as consistent as possible across organizations (e.g., reminders were worded identically and provided at the same time in the data collection process at all organizations); however, it is possible that these slight methodological differences could have impacted who was likely to participate and ultimately the results. These differences in methodologies were relatively minor, and therefore are not likely to have had a substantial influence on the findings.

\section{Future Research}

As this is the first investigation of the relationship between work relationships, continuance commitment, and intentions to quit, there is still much to learn and understand. One potential area for further understanding is to establish the causal relationship between work relationships and continuance commitment. This can be accomplished using a combination of longitudinal data collection and causal modeling. Work relationships should be measured along with continuance commitment at a series of points in time to assess their current state as well as the change in the relationship between them over time. Using causal modeling techniques such as path analysis, the direction of causality between them can be established. Demonstrating that work relationships are an antecedent of continuance commitment, and not vice versa, will give researchers more confidence to suggest to organizations that improving work relationships among employees is an effective way to positively affect continuance commitment and ultimately intentions to quit.

Another source of potential investigation is what other work relationship characteristics may be relevant predictors of continuance commitment and intentions to quit. This study found that network size predicts continuance commitment and network relationship quality predicts 
intentions to quit. There may be other characteristics not measured in this study that could also help to further explain these outcomes. One possible characteristic may be how long of a relationship the participant has had with each of the network contacts; perhaps longer relationships are a greater investment. Also, perhaps it is not the entire network that is most important in predicting outcomes, but rather a select few contacts within the network that are most influential. Such contacts could be identified by asking participants to rank order the contacts, or indicate the five most influential contacts among all contacts listed. Participant relationships with only their most influential contacts could then be analyzed to see if they have a unique impact on the outcomes.

It would also be interesting to study what other outcomes of interest work relationships may impact. Their effect on other job attitudes like job satisfaction and job involvement, behaviors such as organizational citizenship behaviors, absenteeism and turnover, and other outcomes such as job-related stress, work accidents, and leader effectiveness, would be valuable to understand.

Conclusion

Work relationships have been studied in several contexts including friendship and exchange relationships. However, not until this study have they been expressly investigated in relation to the outcomes of continuance commitment and intentions to quit. This study was a first empirical step toward providing more insight and understanding into the impact of work relationships on these outcomes, and also for presenting an empirical basis for continued investigation on this topic. These findings have identified two network constructs, network size and network relationship quality, which have implications for continuance commitment and intentions to quit. Future research should attempt to replicate these findings, explore new 
relationship constructs, and identify other outcomes that can be further understood by examining their association with work relationship constructs. 


\section{REFERENCES}

Adkins, C. L. (1995). Previous work experience and organizational socialization: A longitudinal examination. Academy of Management Journal, 38, 839-862.

Allen, N. J., \& Meyer, J. P. (1990). The measurement and antecedents of affective, continuance, and normative commitment to the organization. Journal of Occupational Psychology, 63, 1-18.

Allen, N. J., \& Meyer, J. P. (1996). Affective, continuance, and normative commitment to the organization: An examination of construct validity. Journal of Vocational Behavior, 49, 252-276.

Alutto, J. A., Hrebiniak, L. G., \& Alonso, R. C. (1973). On operationalizing the concept of commitment. Social Forces, 51, 448-454.

Arnold, H. J., \& Feldman, D. C. (1982). A multivariate analysis of the determinants of job turnover. Journal of Applied Psychology, 67, 350-360.

Baluch, B., Martin, G. N., Christian, L., \& Corulla, W. J. (1996). Psychology and nonpsychology students' estimation of their desirable and undesirable personality traits. Personality \& Individual Differences, 21, 617-620.

Baron, R. M., \& Kenny, D. A. (1986). The moderator-mediator variable distinction in social psychological research: Conceptual, strategic, and statistical considerations. Journal of Personality and Social Psychology, 51, 1173-1182.

Baumeister, R. F., \& Leary, M. R. (1995). The need to belong: Desire for interpersonal attachments as a fundamental human motivation. Psychological Bulletin, 117, p. 497529. 
Becker, H. S. (1960). Notes on the concept of commitment. American Journal of Sociology, 66, 32-42.

Becker, H. S. (1964). Personal change in adult life. Sociometry, 28, 40-53.

Berman, E. M., West, J. P., \& Richter, M. N. Jr. (2002). Workplace relations: Friendship patterns and consequences (according to managers). Public Administration Review, 62, 217-230.

Berry, D. S., Willingham, J. K., \& Thayer, C. A. (2000). Affect and personality as predictors of conflict and closeness in young adults’ friendships. Journal of Research in Personality, 34, 84-107.

Berscheid, E. (1985). Interpersonal attraction. In G. Lindzey \& E. Aronson (Eds.), Handbook of Social Psychology (Vol. 2, pp. 413-484). New York: Academic Press.

Berube, M. S., Costello, R. B., Jost, D. A., Ellis, K., \& Severynse, M. (1997). The American heritage college dictionary ( $3^{\text {rd }}$ ed.). Boston: Houghton Mifflin.

Bhal, K. T., \& Ansari, M. A. (1996). Measuring quality of interaction between leaders and members. Journal of Applied Social Psychology, 26, 945-972.

Blair-Loy, M., \& Wharton, A. S. (2004). Organizational commitment and constraints on workfamily policy use: Corporate flexibility policies in a global firm. Sociological Perspectives, 47, 243-267.

Blau, G. J. (1986). Job involvement and organizational commitment as interactive predictors of tardiness and absenteeism. Journal of Management, 12, 577-584.

Blau, P. M. (1964). Exchange and power in social life. New York: Wiley.

Borman, W. C., \& Motowidlo, S. J. (1993). Expanding the criterion domain to include elements of contextual performance. In N. Schmitt and W. C. Borman (Eds.), Personnel selection in organizations (pp. 71-98). San Francisco: Jossey-Bass. 
Buchanan, B. (1974). Building organizational commitment: The socialization of managers in work organizations. Administrative Science Quarterly, 19, 533-546.

Burgess, E. W., \& Wallin, P. (1943). Homogamy in social characteristics. American Journal of Sociology, 49, 109-124.

Bycio, P., Hackett, R. D., \& Allen, J. S. (1995). Further assessments of Bass’s (1985) conceptualization of transactional and transformational leadership. Journal of Applied Psychology, 80, 468-478.

Campbell, K. E., Marsden, P. V., \& Hurlbert, J. S. (1986). Social resources and socioeconomic status. Social Networks, 8, 97-117.

Campion, M. A., Medsker, G. J., \& Higgs, A. C. (1993). Relations between work group characteristics and effectiveness: Implications for designing effective work groups. Personnel Psychology, 46, 823-850.

Clarke, A. C. (1952). An examination of the operation of residual propinquity as a factor in mate selection. American Sociological Review, 27, 17-22.

Cohen, S. G., \& Bailey, D. E. (1997). What makes teams work: Group effectiveness research from the shop floor to the executive suite. Journal of Management, 23, 239-290.

Coleman, D. F., Irving, G. P., \& Cooper, C. L. (1999). Another look at the locus of controlorganizational commitment relationship: It depends on the form of commitment. Journal of Organizational Behavior, 20, 995-1001. 
Crossley, C. D., Lin, L. F., \& Stanton, J. M. (2002, April). Assessing the content validity of intention to quit scales. In J. M. Stanton, Crossley, C. D., \& L. F. Lin (Co-chairs), New directions and considerations in research examining voluntary turnover. Symposium conducted at the annual meeting of the Society for Industrial and Organizational Psychology, Toronto, Canada.

Dansereau, F., Graen, G., \& Haga, W. (1975). A vertical dyad linkage approach to leadership in formal organizations. Organizational Behavior and Human Performance, 13, $46-78$.

DeCotiis, T. A., \& Summers, T. P. (1987). A path analysis of a model of the antecedents and consequences of organizational commitment. Human Relations, 40, 445-470.

Dunegan, K. J., Tierney, P., \& Duchon, D. (1992). Perceptions of an innovative climate: Examining the role of divisional affiliation, work group interaction, and leader/subordinate exchange. IEEE Transactions on Engineering Management, 39, 227235.

Dunham, R. B., Grube, J. A., \& Castaneda, M. B. (1994). Organizational commitment: The utility of an integrative definition. Journal of Applied Psychology, 79, 370-380.

Eisenberger, R., Huntington, R., Hutchison, S., \& Sowa, D. (1986). Perceived organizational support. Journal of Applied Psychology, 71, 500-507.

Erdheim, J., Wang, M., Zickar, M. J. (2006). Linking the Big Five personality constructs to organizational commitment. Personality and Individual Differences, 41, 959-970.

Farrell, D., \& Rusbult, C. E. (1981). Exchange variables as predictors of job satisfaction, job commitment, and turnover: The impact of rewards, costs, alternatives, and investments. Organizational Behavior and Human Performance, 28, 78-95. 
Fine, G. A. (1986). Friendships in the workplace. In V. J. Derlega \& B. A. Winstead (Eds.), Friendship and social interaction (pp. 185-206). New York: Springer-Verlag.

Gakovic, A. \& Tetrick, L. E. (2003). Perceived organizational support and work status: A comparison of the employment relationships of part-time and full-time employees attending university classes. Journal of Organizational Behavior, 24, 649-666.

Gellatly, I. R. (1995). Individual and group determinants of employee absenteeism: Test of a causal model. Journal of Organizational Behavior, 16, 469-485.

Gersick, C. J. G., Bartunek, J. M., \& Dutton, J. E. (2000). Learning from academia: The importance of relationships in personal life. Academy of Management Journal, 43, 10261044.

Gerstner, C. R., \& Day, D. V. (1997). Meta-analytic review of leader-member exchange theory: Correlates and construct issues. Journal of Applied Psychology, 82, 827-844.

Graen, G. B., \& Scandura, T. (1987). Toward a psychology of dyadic organizing. In B. Staw \& L. L. Cummings (Eds.), Research in organizational behavior (Vol. 9, pp. 175-208). Greenwich, CT: JAI.

Greenberg, J. (2002). Managing behavior in organizations ( $3^{\text {rd }}$ ed.). Upper Saddle River, NJ: Prentice Hall.

Gregersen, H. B. (1993). Multiple commitments at work and extra-role behaviors during three stages of organizational tenure. Journal of Business Research, 26, 31-47.

Hall, D. T., Schneider, B., \& Nygren, H. T. (1970). Personal factors in organizational identification. Administrative Science Quarterly, 15, 176-190.

Heider, F. (1958). The psychology of interpersonal relationships. New York: Wiley. 
Heyl, V. (2004). Friendships in middle and older age: The result of early childhood experiences. Zeitschrift fur Gerontologie und Geriatrie, 37, 357-359.

Hill, C. A. (1987). Affiliation motivation: People who need people...but in different ways. Journal of Personality and Social Psychology, 52, 1008-1018.

Hrebiniak, L. G., \& Alluto, J. A. (1972). Personal and role-related factors in the development of organizational commitment. Administrative Science Quarterly, 17, 555-573.

Ibarra, H. (1993). Personal networks of women and minorities in management: A conceptual framework. Academy of Management Review, 18, 56-87.

Ibarra, H. (1995). Race, opportunity, and diversity of social circles in managerial networks. Academy of Management Journal, 38, 673-703.

Ilgen, D. R., \& Hollenback, J. H. (1977). The role of job satisfaction in absence behavior. Organizational Behavior and Human Performance, 19, 148-161.

Jaros, S. T., Jermier, J. M., Koehler, J. W., \& Sincich, T. (1993). Effects of continuance, affective, and moral commitment on the withdrawal process: An evaluation of eight structural equation models. Academy of Management Journal, 36, 951-995.

Jayne, M. (1994). Family role identification as a source of gender differences in the relationship between parenthood and organizational commitment. Unpublished doctoral dissertation, Tulane University, New Orleans, LA.

Jex, S. M., \& Bliese, P. D. (1999). Efficacy beliefs as a moderator of the impact of work-related stressors: A multilevel study. Journal of Applied Psychology, 84, 349-361.

Kandel, D. (1978). Similarity in real-life adolescent friendship pairs. Journal of Personality and Social Psychology, 36, 306-312. 
Kanter, R. M. (1968). Commitment and social organization: A study of commitment mechanisms in utopian communities. American Sociological Review, 33, 499-517.

Katz, R. (1978). Job longevity as a situational factor in job satisfaction. Administrative Science Quarterly, 23, 204-223.

Kiesler, C. A. (1971). The psychology of commitment: Experiments linking behavior to belief. San Diego, CA: Academic Press.

Koch, J. T., \& Steers, R. M. (1978). Job attachment, satisfaction, and turnover among public sector employees. Journal of Vocational Behavior, 12, 119-128.

Konovsky, M. A., \& Cropanzano, R. (1991). Perceived fairness of employee drug testing as a predictor of employee attitudes and job performance. Journal of Applied Psychology, 76, 698-707.

Koys, D. J. (1988). Human resource management and a culture of respect: Effects on employees’ organizational commitment. Employee Responsibilities and Rights Journal, 1, 57-68.

Koys, D. J. (1991). Fairness, legal compliance, and organizational commitment. Employee Responsibilities and Rights Journal, 4, 283-291.

Krackhardt, D., \& Porter, L. W. (1985). When friends leave: A structural analysis of the relationship between turnover and stayer's attitudes. Administrative Science Quarterly, 30, 242-261.

Kram, K. E., \& Isabella, L. A. (1985). Mentoring alternatives: The role of peer relationships in career development. Academy of Management Journal, 28, 110-132.

Landy, F. J., \& Conte, J. M. (2004). Work in the $21^{\text {st }}$ Century. Boston: McGraw Hill.

Lee, K. B. (1992). A study of affective, continuance, and normative commitment to the organization. Unpublished master’s thesis, Sung Jyun Kwan University, Seoul, Korea. 
Liden, R. C., Wayne, S. J., \& Sparrowe, R. T. (2000). An examination of the mediating role of psychological empowerment on the relationships between job, interpersonal relationships, and work outcomes. Journal of Applied Psychology, 85, 407-416.

Lynn, S. A., Cao, L. T., \& Horn, B. C. (1996). The influence of career stage on the work attitudes of male and female accounting professionals. Journal of Organizational Behavior, 17, 135-149.

Major, D. A., Kozlowski, S. W. J., Chao, G. T., \& Gardner, P. D. (1995). A longitudinal investigation of newcomer expectations, early socialization outcomes, and the moderating effects of role development factors. Journal of Applied Psychology, 80, 418431.

Marsh, R. M., \& Mannari, H. (1977). Organizational commitment and turnover: A predictive study. Administrative Science Quarterly, 22, 57-75.

Martin, R., Thomas, G., Charles, K., Epitropaki, O., \& McNamara, R. (2005). The role of leadermember exchanges in mediating the relationship between locus of control and work reactions. Journal of Occupational and Organizational Psychology, 78, 141-147.

Mathieu, J. E., \& Zajac, D. (1990). A review and meta-analysis of the antecedents, correlates, and consequences of organizational commitment. Psychological Bulletin, 108, 171-194.

Mayer, R. C., \& Schoorman, F. D. (1992). Predicting participation and production outcomes through a two-dimensional model of organizational commitment. Academy of Management Journal, 35, 671-684.

McGee, G. W., \& Ford, R. C. (1987). Two (or more?) dimensions of organizational commitment: Reexamination of the affective and continuance commitment scales. Journal of Applied Psychology, 72, 638-642. 
Meleddu, M., \& Guicciardi, M. (1998). Self-knowledge and social desirability of personality traits. European Journal of Personality, 12, 151-168.

Meyer, J. P., \& Allen, N. J. (1991). A three-component conceptualization of organizational commitment. Human Resource Management Review, 1, 61-89.

Meyer, J. P., \& Allen, N. J. (1997). Commitment in the workplace: Theory, research, and application. Thousand Oaks, CA: Sage.

Meyer, J. P., Allen, N. J., \& Smith, C. A. (1993). Commitment to organizations and occupations: Extension and test of a three-component conceptualization. Journal of Applied Psychology, 78, 538-551.

Meyer, J. P., Bobocel, D. R., \& Allen, N. J. (1991). Development of organizational commitment during the first year of employment: A longitudinal study of pre- and post-entry influences. Journal of Management, 17, 717-733.

Meyer, J. P., \& Herscovitch, L. (2001). Commitment in the workplace: Toward a general model. Human Resource Management Review, 11, 299-326.

Meyer, J. P., Stanley, D. J., Herscovitch, L., \& Topolnytsky, L. (2002). Affective, continuance and normative commitment to the organization: A meta-analysis of antecedents, correlates, and consequences. Journal of Vocational Behavior, 61, 20-52.

Miller, J., \& Labovitz, S. (1973). Individual reactions to organizational conflict and change. The Sociological Quarterly, 14, 556-575.

Mitchell, T. R., Holtom, B. C., Lee, T. W., Sablynski, C. J., \& Erez, M. (2001). Why people stay: Using job embeddedness to predict voluntary turnover. Academy of Management Journal, 44, 1102-1121. 
Morrison, E. W. (2002). Newcomers’ relationships: The role of social network ties during socialization. Academy of Management Journal, 45, 1149-1160.

Mottaz, C. J. (1988). Determinants of organizational commitment. Human Relations, 41, 467482.

Mount, M. K., Barrick, M. R., \& Stewart, G. L. (1998). Five-factor model of personality and performance in jobs involving interpersonal interactions. Human Performance, 11, 145165.

Mowday, R. T., Porter, L. W., \& Steers, R. M. (1982). Organization linkages: The psychology of commitment, absenteeism, and turnover. San Diego, CA: Academic Press.

Murray, H. (1938). Explorations in personality. New York: Oxford University Press.

Myers, D. G. (1996). Social Psychology (5 ${ }^{\text {th }}$ ed.). New York: McGraw Hill.

Naquin, S. S., \& Holton, E. F., III. (2002). The effects of personality, affectivity, and work commitment on motivation to improve work through learning. Human Resource Development Quarterly, 13, 357-376.

Nicholson, N., Wall, T., \& Lischeron, J. (1977). The predictability of absence and propensity to leave from employees' job satisfaction and attitudes toward influence in decision-making. Human Relations, 30, 499-514.

Nielsen, I. K., Jex, S. M., \& Adams, G. A. (2000). Development and validation of scores on a two-dimensional workplace friendship scale. Educational and Psychological Measurement, 60, 628-643.

O’Hara, K. B., Beehr, T. A., \& Colarelli, S. M. (1994). Organizational centrality: A third dimension of intraorganizational career movement. The Journal of Applied Behavioral Science, 30, 198-216. 
O’Reilly, C. A., \& Chatman, J. (1986). Organizational commitment and psychological attachment: The effects of compliance, identification, and internalization on prosocial behavior. Journal of Applied Psychology, 71, 492-499.

Organ, D. W., \& Ryan, K. (1995). A meta-analytic review of attitudinal and dispositional predictors of organizational citizenship behavior. Personnel Psychology, 48, 775-802.

Penley, L. E., \& Gould, S. (1988). Etzioni’s model of organizational involvement: A perspective for understanding commitment to organizations. Journal of Organizational Behavior, 9, 43-59.

Peters, L. H., Jackofsky, E. F., \& Salter, J. R. (1981). Predicting turnover: A comparison of parttime and full-time employees. Journal of Occupational Behaviour, 2, 89-98.

Pinder, C. C. (1998). Work motivation in organizational behavior. Upper Saddle River, NJ: Prentice Hall.

Podolny, J. M., \& Baron, J. N. (1997). Resources and relationships: Social networks and mobility in the workplace. American Sociological Review, 62, 673-693.

Podsakoff, P. M., MacKenzie, S. B., Paine, J. B., \& Bachrach, D. G. (2000). Organizational citizenship behaviors: A critical review of the theoretical and empirical literature and suggestions for future research. Journal of Management, 26, 513-563.

Porter, L. W., Steers, R. M., Mowday, R. T., \& Boulian, P. V. (1974). Organizational commitment, job satisfaction, and turnover among psychiatric technicians. Journal of Applied Psychology, 59, 603-609.

Randall, D. M. (1990). The consequences of organizational commitment: Methodological investigation. Journal of Organizational Behavior, 11, 351-378. 
Rhodes, S. R., \& Steers, R. M. (1981). Conventional vs. worker-owned organizations. Human Relations, 12, 1013-1035.

Ritzer, G., \& Trice, H. M. (1969). An empirical study of Howard Becker’s side-bet theory. Social Forces, 47, 475-479.

Robinson, S. L., \& Rousseau, D. M. (1994). Violating the psychological contract: Not the exception but the norm. Journal of Organizational Behavior, 15, 245-259.

Rusbult, C. E. (1980). Commitment and satisfaction in romantic associations: A test of the investment model. Journal of Experimental Social Psychology, 16, 172-186.

Rusbult, C. E., \& Farrell, D. (1983). A longitudinal test of the investment model: The impact on job satisfaction, job commitment, and turnover of variations in rewards, costs, alternatives, and investments. Journal of Applied Psychology, 68, 429-438.

Russell, S. S., Spitzmueller, C., Lin, L. F., Stanton, J. M., \& Smith, P. C. (2002). Shorter can also be better: The abridged job in general scale. Bowling Green State University, Unpublished manuscript.

Saks, A. M. (1995). Longitudinal field investigation of the moderating and mediating effects of self-efficacy on the relationship between training and newcomer adjustment. Journal of Applied Psychology, 80, 211-225.

Sanchez, J. I., Korbin, W. P., Viscarra, D. M. (1995). Corporate support in the aftermath of a natural disaster: Effects on employee strains. Academy of Management Journal, 38, 504521.

Sarason, I. G., \& Sarason, B. R. (Eds.). (1985). Social support: Theory, research and applications. Dordrecht, The Netherlands: Martinus Nijhoff Publishers. 
Saucier, G. (1994). Mini-markers: A brief version of Goldberg’s unipolar big-five markers. Journal of Personality Assessment, 63, 506-516.

Scholl, R. W. (1981). Differentiating commitment from expectancy as a motivating force. Academy of Management Review, 6, 589-599.

Scott, J. (2000). Social network analysis: A handbook ( $2^{\text {nd }}$ ed.). London: Sage Publications.

Seers, A. (1989). Team-member exchange quality: A new construct for role-making research. Organizational Behavior and Human Decision Processes, 43, 118-135.

Sheldon, M. E. (1971). Investments and involvements as mechanisms producing commitment to the organization. Administrative Science Quarterly, 16, 143-150.

Sherony, K. M., \& Green, S. G. (2002). Coworker exchange: Relationships between coworkers, leader-member exchange, and work attitudes. Journal of Applied Psychology, 87, 542548.

Sias, P. M., Heath, R. G., Perry, T., Silva, D., \& Fix, B. (2004). Narratives of workplace friendship deterioration. Journal of Social and Personal Relationships, 21, 321-340.

Spector, P. E. (1988). Development of the work locus of control scale. Journal of Occupational Psychology, 61, 335-340.

Stanton, J. M., \& Rogelberg, S. G. (2001). Using Internet/Intranet web pages to collect organizational research data. Organizational Research Methods, 4, 199-216.

Stanton, J. M., Sinar, E. F., Balzer, W. K., Julian, A. L., Thoreson, P., Aziz, S., Fisher, G. G., \& Smith, P. C. (2002). Development of a compact measure of job satisfaction: The abridged job descriptive index. Educational and Psychological Measurement, 62, 173-191. 
Staw, B. M. (1980). Rationality and justification in organizational life. In B. M. Staw \& L. L. Cummings (Eds.), Research in organizational behavior (Vol. 2, pp. 45-80). Greenwich, CT: JAI Press.

Steers, R. M. (1977). Antecedents and outcomes of organizational commitment. Administrative Science Quarterly, 22, 46-56.

Stevens, J. M., \& Beyer, J. M., \& Trice, H. M. (1978). Assessing personal, role, and organizational predictors of managerial commitment. Academy of Management Journal, 21, 380-396.

Tabachnick, B. G., \& Fidell, L. S. (1996). Using multivariate statistics (3 ${ }^{\text {rd }}$ ed.). New York: Harper Collins.

Thibaut, J. W., \& Kelley, H. H. (1959). The social psychology of groups. New York: John Wiley \& Sons, Inc.

Tierney, P., Farmer, F. M., \& Graen, G. B. (1999). An examination of leadership and employee creativity: The relevance of traits and relationships. Personnel Psychology, 52, 591-620.

Wanous, J. P., Poland, T. D., Premack, S. L., \& Davis, K. S. (1992). The effects of met expectations on newcomer attitudes and behaviors: A review and meta-analysis. Journal of Applied Psychology, 77, 288-297.

Wasserman, S., \& Faust, K. (1994). Social network analysis: Methods and applications. Cambridge: Cambridge University Press.

Welsch, H. P., \& LaVan, H. (1981). Inter-relationships between organizational commitment and job characteristics, job satisfaction, professional behavior, and organizational climate. Human Relations, 34, 1079-1089. 
Whitener, E. M., \& Walz, P. M. (1993). Exchange theory determinants of affective and continuance commitment and turnover. Journal of Vocational Behavior, 42, 265-281.

Wiener, Y. (1982). Commitment in organizations: A normative view. Academy of Management Review, 7, 418-428.

Wiener, Y., \& Gechman, A. S. (1977). Commitment: A behavioral approach to job involvement. Journal of Vocational Behavior, 10, 47-52.

Winstead, B. A., Derlega, V. J., Montgomery, M. J., \& Pilkington, C. (1995). The quality of friendships at work and job satisfaction. Journal of Social and Personal Relationships, 12, $199-215$.

Yager, J. (1997). Friendshifts: The power of friendship and how it shapes our lives. Stamford, CT: Hannacroix Creek Books. 
Appendix A: Invitation E-mail 


\section{Dear $<<$ Company Name $>>$ Employee:}

My name is Melissa Cohen, and I am a doctoral student at Bowling Green State University in Ohio and a member of Dr. Steve Jex's research team. I am currently conducting research on relationships at work.

Have you ever wondered how your relationships with others at work affect you at work? This study is an opportunity for you to share your thoughts and opinions and play an active role in improving our understanding of the role of work relationships in the workplace. In order to complete the study, I need your assistance with a brief survey. By participating in this study, not only will you be helping me with my research and helping to potentially improve relationships in the workplace, but I will also enter you in a raffle in which YOU COULD WIN \$300. Further instructions are included in the survey. Please read all instructions carefully.

As a researcher, I am ethically bound to keep your responses to this survey completely confidential. Your responses will be combined with those from all other participants, and only the overall results will be reported. We encourage you to complete this survey during your personal or break time while at work or outside of your regular work hours so as not to interfere with your regular job duties. The survey should take you approximately 15-20 minutes to complete. You will have two weeks from today, until $<<$ two weeks from survey invitation $>>$, to complete this survey.

Your participation would be greatly appreciated. If you might be willing to participate, please go to this website:

$<<$ Survey Web Address $>>$

However, your participation is entirely voluntary, so if you choose not to participate you need not do anything.

Please feel free to contact me with any questions or concerns.

Sincerely,

Melissa A. Cohen, M.A.

Bowling Green State University: Department of Psychology

Bowling Green, OH 43402

Phone: (419) 874-2039

E-mail: mcohen@bgsu.edu 
Appendix B: Reminder E-mails 
First Reminder

Dear $<<$ Company Name $>>$ Employee,

This is just a friendly reminder that you have only one more week (next $<<$ Corresponding Date $>>$ is the last day!) in which to complete the survey on Work Relationships. If you have already completed it, then please accept my sincerest thanks, and feel free to ignore this email. If you have not yet completed it, then I urge you to take this opportunity to do so. Don't forget that just a few minutes of your time could win you \$300! An additional copy of the original invitation is below for your information. Thank you!

Sincerely,

Melissa A. Cohen, M.A.

Bowling Green State University: Department of Psychology

Bowling Green, OH 43402

Phone: (419) 874-2039

E-mail: mcohen@bgsu.edu

Second Reminder

Dear $<<$ Company Name $>>$ Employee,

Last chance! This is just a friendly reminder that you have only TWO MORE DAYS $(<<$ Corresponding Date $>>$ is the last day!) in which to complete the survey on Work Relationships. This is the LAST reminder you will receive. If you have already completed it, then please accept my sincerest thanks, and feel free to ignore this email. If you have not yet completed it, then I urge you to take this opportunity to do so. Don't forget that just a few minutes of your time could win you \$300! An additional copy of the original invitation is below for your information. Thank you!

Sincerely,

Melissa A. Cohen, M.A.

Bowling Green State University: Department of Psychology

Bowling Green, OH 43402

Phone: (419) 874-2039

E-mail: mcohen@bgnet.bgsu.edu 
Appendix C: Participant Survey 


\section{WORK RELATIONSHIPS}

Bowling Green State University

\section{FILL OUT THIS SURVEY AND YOU COULD WIN \$300!}

\section{A. STUDY INTRODUCTION}

Researchers at Bowling Green State University are examining employees' relationships with others at work to learn how such relationships affect employees in the course of their job. We hope to use what we learn from this study to help organizations understand their employees better, particularly their social dynamics and interpersonal needs. Ultimately, we hope this study will lead to improvements in quality of work life, organizational practices and organizational effectiveness. By participating in this study, you will experience how psychological research is carried out, what researchers are doing to try to improve the workplace, and perhaps most important, know that your experiences and opinions may contribute to how organizations operate in the future.

Participating in this study and providing your email address will enter you in a drawing to win a cash prize of $\$ 300$. You will be prompted to enter your email address later in this survey if you would like to enter the raffle. The raffle will take place on or before Saturday, July 8, 2006. If you win the raffle you will be contacted via email within a week of the raffle. Your email address will only be used for purposes of contacting you if you win the raffle, and will not be tied to your responses in any way.

\section{REQUIREMENTS TO PARTICIPATE:}

You may participate in this research if:

1. You are at least 18 years of age

2. You have been employed by your organization for AT LEAST six months

3. You are based in the United States

Your participation in this research is entirely voluntary. Please answer the following questions as completely as you can, but feel free to skip any question that makes you uncomfortable. You may also withdraw your participation at any time without penalty. By completing the survey and submitting it to the researchers, you are providing your consent to participate in this research, and you agree that you fulfill all requirements listed above.

If you choose to enter the raffle, you may enter any email address you choose as long as we will be able to contact you easily in the event that you win the raffle. We encourage you to complete this survey either during your personal or break time while at work or 
outside of your regular work hours so as not to interfere with your regular job duties. To further protect your privacy and confidentiality, you may also choose to complete this survey outside of work from a home or personal computer. The survey will take approximately 15-20 minutes to complete.

We will keep your answers strictly confidential. Please protect your identity by not providing any personally identifying information (e.g., you name, address, telephone number) anywhere in your responses. In our reports we will only show aggregated results (i.e., your results will be combined with all other results) to protect the confidentiality of your responses. Note that it is impossible to provide a $100 \%$ guarantee of the security of information submitted over the Internet.

We encourage you to contact Melissa Cohen (419) 874-2039, mcohen@bgsu.edu or Dr. Steve Jex (419) 372-2301, sjex@bgnet.bgsu.edu with any questions you have either before, during, or after you complete the survey. You may also contact Melissa if you wish to obtain a copy of a report describing the results of this research when it is completed. You may also contact the chair of the Human Subjects Review Board (HSRB) at Bowling Green State University (419) 372-7716 with any questions or concerns of an ethical nature that you may have.

\section{B. IMPORTANT ADDITIONAL INSTRUCTIONS}

Part of this survey will ask you to provide information about your relationships with specific individuals at work as well as other information about your work experiences and attitudes. At no time will this information be available to anyone other than the research team. All information that you provide in this survey will remain confidential, both during the study and after it is completed. As previously mentioned, your responses will be combined with those from all other participants, and only overall, aggregated results will be reported. At no time will your individual responses be identifiable to anyone other than the research team. If you have any questions about this assurance please feel free to contact one of the researchers.

When you have completed the survey, make sure to click on the "DONE" button at the end of this webpage. You will know that your survey has been submitted if after you click on the "DONE" button a new page appears that says "Survey Submitted" at the top.

Be sure to NOT click on the "DONE" before you complete the survey. This may result in an incomplete reporting of your results, and may disqualify you from the raffle. You must, however, click on the "DONE" button when you have completed the survey. If you fail to click on this button your results will not be reported, and you will be ineligible for the raffle. If you have any questions or concerns about this procedure, please contact me at 419-874-2039 or e-mail me at mcohen@bgsu.edu. 
C. SURVEY QUESTIONS

In this section, you will be asked to identify various individuals you work with using their initials, as well as provide information about your relationship with each of those individuals. Please note that we will not in any way attempt to use the information you provide to identify you or the individuals you name.

1. Please identify your primary supervisor using his or her initials (e.g., John Smith = JS), and then answer the remaining questions about that individual.

\begin{tabular}{|l|l|l|}
\hline $\begin{array}{l}\text { Primary Supervisor } \\
\text { Initials }\end{array}$ & $\begin{array}{l}\text { How frequently do you interact } \\
\text { with this person at work? }\end{array}$ & $\begin{array}{l}\text { Overall, how would you rate the quality of } \\
\text { your work relationship with this person? }\end{array}$ \\
\hline & $\square$ Daily & $\square$ Outstanding \\
& $\begin{array}{l}\text { A few times a week } \\
\text { Very good }\end{array}$ \\
& $\begin{array}{l}\text { 3-5 times a month } \\
\text { Once or twice a month } \\
\text { Less than once a month }\end{array}$ & $\square$ Fair \\
& $\square$ Poor \\
\hline
\end{tabular}

2. Please identify up to eight coworkers, individuals you work with most often at work, that you do not report to nor do they report to you, using their initials (e.g., John Smith = JS). You are not required to fill all eight selections: list as many or as few people as are relevant. Then, please answer the remaining questions about each individual that you name.

\begin{tabular}{|c|c|c|c|c|c|}
\hline & $\begin{array}{l}\text { Coworker } \\
\text { Initials }\end{array}$ & $\begin{array}{l}\text { Did you list this } \\
\text { person above as } \\
\text { your primary } \\
\text { supervisor? }\end{array}$ & $\begin{array}{l}\text { How frequently do you } \\
\text { interact with this person at } \\
\text { work? }\end{array}$ & $\begin{array}{l}\text { Relative to yourself, on what level } \\
\text { in your organization is this } \\
\text { individual? }\end{array}$ & $\begin{array}{l}\text { Overall, how would you } \\
\text { rate the quality of your } \\
\text { work relationship with } \\
\text { this person? }\end{array}$ \\
\hline 1 & & \begin{tabular}{|l}
$\square$ Yes \\
$\square$ No
\end{tabular} & \begin{tabular}{|l|l}
$\square$ & Daily \\
$\square$ & A few times a week \\
$\square$ & 3-5 times a month \\
$\square$ & Once or twice a month \\
$\square$ & Less than once a month
\end{tabular} & $\begin{array}{l}\square \text { Lower level than myself } \\
\square \text { About the same level as myself } \\
\square \text { Higher level than myself }\end{array}$ & \begin{tabular}{|l}
$\square$ Outstanding \\
$\square$ Very good \\
$\square$ Good \\
$\square$ Fair \\
$\square$ Poor
\end{tabular} \\
\hline 2 & & $\begin{array}{l}\square \text { Yes } \\
\text { No }\end{array}$ & $\begin{array}{ll}\square & \text { Daily } \\
\square & \text { A few times a week } \\
\square & \text { 3-5 times a month } \\
\square & \text { Once or twice a month } \\
\square & \text { Less than once a month }\end{array}$ & $\begin{array}{l}\square \text { Lower level than myself } \\
\square \text { About the same level as myself } \\
\square \text { Higher level than myself }\end{array}$ & $\begin{array}{l}\square \text { Outstanding } \\
\square \text { Very good } \\
\square \text { Good } \\
\square \text { Fair } \\
\square \text { Poor }\end{array}$ \\
\hline
\end{tabular}




\begin{tabular}{|c|c|c|c|c|}
\hline 3 & $\begin{array}{l}\square \text { Yes } \\
\square \text { No }\end{array}$ & $\begin{array}{l}\square \text { Daily } \\
\square \text { A few times a week } \\
\square \text { 3-5 times a month } \\
\square \text { Once or twice a month } \\
\square \text { Less than once a month }\end{array}$ & $\begin{array}{l}\square \text { Lower level than myself } \\
\square \text { About the same level as myself } \\
\square \text { Higher level than myself }\end{array}$ & \begin{tabular}{|l|l}
$\square$ & Outstanding \\
$\square$ & Very good \\
$\square$ & Good \\
$\square$ & Fair \\
$\square$ & Poor \\
\end{tabular} \\
\hline 4 & $\begin{array}{l}\square \text { Yes } \\
\square \text { No }\end{array}$ & $\begin{array}{l}\text { Daily } \\
\square \text { A few times a week } \\
\square \text { 3-5 times a month } \\
\square \text { Once or twice a month } \\
\square \text { Less than once a month }\end{array}$ & $\begin{array}{l}\square \text { Lower level than myself } \\
\square \text { About the same level as myself } \\
\square \text { Higher level than myself }\end{array}$ & $\begin{array}{ll}\square & \text { Outstanding } \\
\square & \text { Very good } \\
\square & \text { Good } \\
\square & \text { Fair } \\
\square & \text { Poor }\end{array}$ \\
\hline 5 & $\begin{array}{c}\square \text { Yes } \\
\square \text { No }\end{array}$ & $\begin{array}{l}\square \text { Daily } \\
\square \text { A few times a week } \\
\square \text { 3-5 times a month } \\
\square \text { Once or twice a month } \\
\square \text { Less than once a month }\end{array}$ & $\begin{array}{l}\square \text { Lower level than myself } \\
\square \text { About the same level as myself } \\
\square \text { Higher level than myself }\end{array}$ & \begin{tabular}{|l}
$\square$ Outstanding \\
$\square$ Very good \\
$\square$ Good \\
$\square$ Fair \\
$\square$ Poor \\
\end{tabular} \\
\hline 6 & $\begin{array}{l}\square \text { Yes } \\
\square \text { No }\end{array}$ & $\begin{array}{l}\text { Daily } \\
\square \text { A few times a week } \\
\square \text { 3-5 times a month } \\
\square \text { Once or twice a month } \\
\square \text { Less than once a month }\end{array}$ & $\begin{array}{l}\text { Lower level than myself } \\
\square \text { About the same level as myself } \\
\square \text { Higher level than myself }\end{array}$ & \begin{tabular}{|l|l}
$\square$ & Outstanding \\
$\square$ & Very good \\
$\square$ & Good \\
$\square$ & Fair \\
$\square$ & Poor \\
\end{tabular} \\
\hline 7 & $\begin{array}{l}\square \text { Yes } \\
\square \text { No }\end{array}$ & $\begin{array}{l}\text { Daily } \\
\square \text { A few times a week } \\
\square \text { 3-5 times a month } \\
\square \text { Once or twice a month } \\
\square \text { Less than once a month }\end{array}$ & $\begin{array}{l}\square \text { Lower level than myself } \\
\square \text { About the same level as myself } \\
\square \text { Higher level than myself }\end{array}$ & 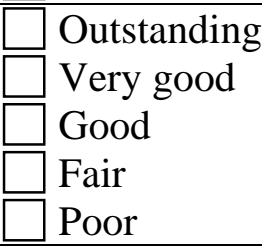 \\
\hline 8 & $\begin{array}{l}\square \text { Yes } \\
\square \text { No }\end{array}$ & $\begin{array}{l}\square \text { Daily } \\
\square \text { A few times a week } \\
\square \text { 3-5 times a month } \\
\square \text { Once or twice a month } \\
\square \text { Less than once a month }\end{array}$ & $\begin{array}{l}\text { Lower level than myself } \\
\square \text { About the same level as myself } \\
\square \text { Higher level than myself }\end{array}$ & \begin{tabular}{|l}
$\square$ Outstanding \\
$\square$ Very good \\
$\square$ Good \\
$\square$ Fair \\
$\square$ Poor \\
\end{tabular} \\
\hline
\end{tabular}


3. Do you supervise anyone (i.e., do you have anyone that directly reports to you)?

$\square$ Yes (Continue)

No (Skip to Q5)

4. Please identify up to eight subordinates, individuals that report to you, using their initials (e.g., John Smith = JS). You are not required to fill all eight selections: list as many or as few people as are relevant. Then, please answer the remaining questions about each individual that you name.

\begin{tabular}{|c|c|c|c|c|}
\hline & $\begin{array}{l}\text { Subordinate } \\
\text { Initials }\end{array}$ & $\begin{array}{l}\text { Did you list this person above } \\
\text { as either your primary } \\
\text { supervisor or a coworker? }\end{array}$ & $\begin{array}{l}\text { How frequently do you } \\
\text { interact with this person at } \\
\text { work? }\end{array}$ & $\begin{array}{l}\text { Overall, how would you rate } \\
\text { the quality of your work } \\
\text { relationship with this } \\
\text { person? }\end{array}$ \\
\hline 1 & & $\begin{array}{c}\square \text { Yes } \\
\square \text { No }\end{array}$ & $\begin{array}{l}\square \text { Daily } \\
\square \text { A few times a week } \\
\square \text { 3-5 times a month } \\
\square \text { Once or twice a month } \\
\square \text { Less than once a month }\end{array}$ & $\begin{array}{ll} & \text { Outstanding } \\
\square \text { Very good } \\
\square \text { Good } \\
\square \text { Fair } \\
\square \text { Poor } \\
\end{array}$ \\
\hline 2 & & \begin{tabular}{|l}
$\square$ Yes \\
$\square$ No
\end{tabular} & \begin{tabular}{l|l} 
& Daily \\
$\square$ & A few times a week \\
$\square$ & 3-5 times a month \\
$\square$ & Once or twice a month \\
$\square$ & Less than once a month
\end{tabular} & \begin{tabular}{|l}
$\square$ Outstanding \\
$\square$ Very good \\
$\square$ Good \\
$\square$ Fair \\
$\square$ Poor \\
\end{tabular} \\
\hline 3 & & $\begin{array}{l}\square \text { Yes } \\
\text { No }\end{array}$ & $\begin{array}{l}\square \text { Daily } \\
\square \text { A few times a week } \\
\square \text { 3-5 times a month } \\
\square \text { Once or twice a month } \\
\square \text { Less than once a month }\end{array}$ & \begin{tabular}{|l}
$\square$ Outstanding \\
$\square$ Very good \\
$\square$ Good \\
$\square$ Fair \\
$\square$ Poor \\
\end{tabular} \\
\hline 4 & & $\begin{array}{l}\square \text { Yes } \\
\text { No }\end{array}$ & \begin{tabular}{l|l} 
& Daily \\
$\square$ & A few times a week \\
$\square$ & 3-5 times a month \\
$\square$ & Once or twice a month \\
$\square$ & Less than once a month
\end{tabular} & $\begin{array}{l}\square \text { Outstanding } \\
\square \text { Very good } \\
\square \text { Good } \\
\square \text { Fair } \\
\square \text { Poor }\end{array}$ \\
\hline
\end{tabular}




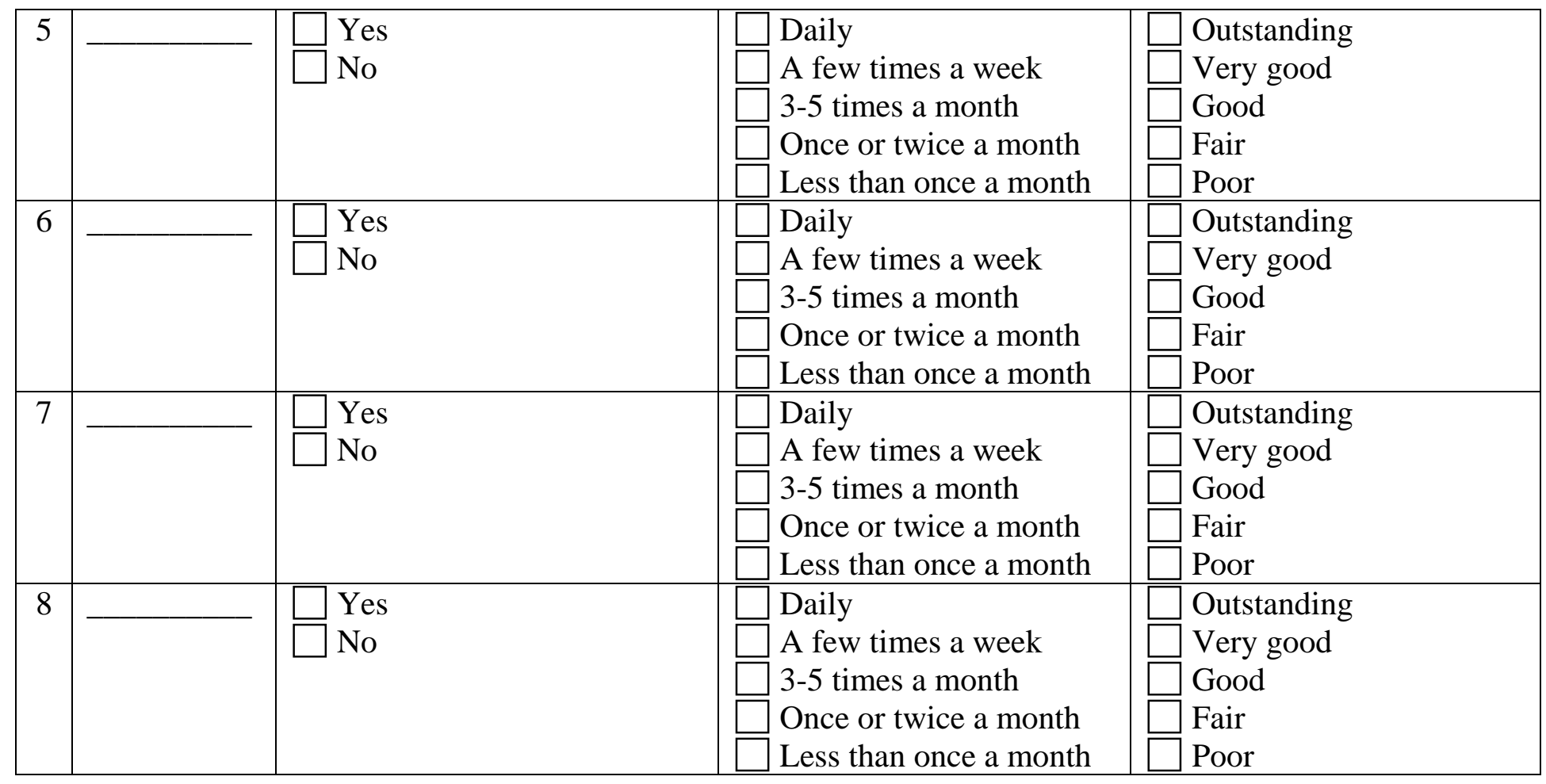


5. Please identify up to eight people you consider to be friends, that is, people whom you might choose to see socially outside of work or when you are not working together, using their initials (e.g., John Smith = JS). You are not required to fill all eight selections: list as many or as few people as are relevant. Then, please answer the remaining questions about each individual that you name.

\begin{tabular}{|c|c|c|c|c|c|c|}
\hline & $\begin{array}{l}\text { Friend } \\
\text { Initials }\end{array}$ & $\begin{array}{l}\text { Did you list } \\
\text { this person } \\
\text { above as your } \\
\text { primary } \\
\text { supervisor, a } \\
\text { coworker, or a } \\
\text { subordinate? }\end{array}$ & $\begin{array}{l}\text { How frequently do you } \\
\text { interact with this person at } \\
\text { work? }\end{array}$ & $\begin{array}{l}\text { Overall, how } \\
\text { would you rate } \\
\text { the quality of } \\
\text { your work } \\
\text { relationship with } \\
\text { this person? }\end{array}$ & $\begin{array}{l}\text { Relative to yourself, on } \\
\text { what level in your } \\
\text { organization is this } \\
\text { individual? }\end{array}$ & $\begin{array}{l}\text { How would you } \\
\text { rate the } \\
\text { closeness of } \\
\text { your } \\
\text { relationship with } \\
\text { this individual? }\end{array}$ \\
\hline 1 & & $\begin{array}{l}\square \text { Yes } \\
\text { No }\end{array}$ & \begin{tabular}{|l}
$\square$ Daily \\
$\square$ A few times a week \\
$\square$ 3-5 times a month \\
$\square$ Once or twice a month \\
$\square$ Less than once a month
\end{tabular} & $\begin{array}{l}\square \text { Outstanding } \\
\square \text { Very good } \\
\square \text { Good } \\
\square \text { Fair } \\
\square \text { Poor } \\
\end{array}$ & $\begin{array}{l}\square \text { Lower level than myself } \\
\square \text { About the same level as } \\
\text { myself } \\
\square \text { Higher level than } \\
\text { myself }\end{array}$ & $\begin{array}{l}\square \text { Very close } \\
\square \text { Reasonably } \\
\text { close } \\
\square \text { Not very } \\
\text { close }\end{array}$ \\
\hline 2 & & $\begin{array}{l}\square \text { Yes } \\
\square \text { No }\end{array}$ & \begin{tabular}{|l}
$\square$ Daily \\
$\square$ A few times a week \\
$\square$ 3-5 times a month \\
$\square$ Once or twice a month \\
$\square$ Less than once a month \\
\end{tabular} & $\begin{array}{l}\text { Outstanding } \\
\text { Very good } \\
\text { Good } \\
\text { Fair } \\
\text { Poor } \\
\end{array}$ & $\begin{array}{l}\square \text { Lower level than myself } \\
\square \text { About the same level as } \\
\text { myself } \\
\square \text { Higher level than } \\
\text { myself }\end{array}$ & $\begin{array}{l}\square \text { Very close } \\
\square \text { Reasonably } \\
\text { close } \\
\square \text { Not very } \\
\text { close } \\
\end{array}$ \\
\hline 3 & & $\begin{array}{l}\square \text { Yes } \\
\square \text { No }\end{array}$ & \begin{tabular}{|l}
$\square$ Daily \\
$\square$ A few times a week \\
$\square$ 3-5 times a month \\
$\square$ Once or twice a month \\
$\square$ Less than once a month
\end{tabular} & $\begin{array}{l}\square \text { Outstanding } \\
\square \text { Very good } \\
\square \text { Good } \\
\square \text { Fair } \\
\square \text { Poor }\end{array}$ & $\begin{array}{l}\square \text { Lower level than myself } \\
\square \text { About the same level as } \\
\text { myself } \\
\square \text { Higher level than } \\
\text { myself }\end{array}$ & $\begin{array}{l}\square \text { Very close } \\
\square \text { Reasonably } \\
\text { close } \\
\square \text { Not very } \\
\text { close }\end{array}$ \\
\hline 4 & & $\begin{array}{l}\square \text { Yes } \\
\square \text { No }\end{array}$ & $\begin{array}{l}\square \text { Daily } \\
\square \text { A few times a week } \\
\square \text { 3-5 times a month } \\
\square \text { Once or twice a month } \\
\square \text { Less than once a month }\end{array}$ & $\begin{array}{l}\square \text { Outstanding } \\
\square \text { Very good } \\
\square \text { Good } \\
\square \text { Fair } \\
\square \text { Poor } \\
\end{array}$ & $\begin{array}{l}\square \text { Lower level than myself } \\
\square \text { About the same level as } \\
\text { myself } \\
\square \text { Higher level than } \\
\text { myself }\end{array}$ & $\begin{array}{l}\square \text { Very close } \\
\square \text { Reasonably } \\
\text { close } \\
\square \text { Not very } \\
\text { close }\end{array}$ \\
\hline
\end{tabular}




\begin{tabular}{|c|c|c|c|c|c|c|}
\hline 5 & & \begin{tabular}{|l}
$\square$ Yes \\
$\square$ No
\end{tabular} & $\begin{array}{l}\square \text { Daily } \\
\square \text { A few times a week } \\
\text { 3-5 times a month } \\
\square \text { Once or twice a month } \\
\square \text { Less than once a month }\end{array}$ & $\begin{array}{l}\text { Outstanding } \\
\text { Very good } \\
\text { Good } \\
\text { Fair } \\
\text { Poor } \\
\end{array}$ & $\begin{array}{l}\square \text { Lower level than myself } \\
\square \text { About the same level as } \\
\text { myself } \\
\square \text { Higher level than } \\
\text { myself }\end{array}$ & $\begin{array}{l}\square \text { Very close } \\
\text { Reasonably } \\
\text { close } \\
\square \text { Not very } \\
\text { close } \\
\end{array}$ \\
\hline 6 & & $\begin{array}{l}\square \text { Yes } \\
\square \text { No }\end{array}$ & \begin{tabular}{|l}
$\square$ Daily \\
$\square$ A few times a week \\
$\square$ 3-5 times a month \\
$\square$ Once or twice a month \\
$\square$ Less than once a month
\end{tabular} & $\begin{array}{l}\text { Outstanding } \\
\text { Very good } \\
\text { Good } \\
\text { Fair } \\
\text { Poor }\end{array}$ & $\begin{array}{l}\square \text { Lower level than myself } \\
\square \text { About the same level as } \\
\text { myself } \\
\square \text { Higher level than } \\
\text { myself }\end{array}$ & $\begin{array}{l}\square \text { Very close } \\
\square \text { Reasonably } \\
\text { close } \\
\square \text { Not very } \\
\text { close }\end{array}$ \\
\hline 7 & & $\begin{array}{l}\square \text { Yes } \\
\square \text { No }\end{array}$ & $\begin{array}{l}\text { Daily } \\
\square \text { A few times a week } \\
\square \text { 3-5 times a month } \\
\square \text { Once or twice a month } \\
\square \text { Less than once a month }\end{array}$ & $\begin{array}{l}\text { Outstanding } \\
\text { Very good } \\
\text { Good } \\
\text { Fair } \\
\text { Poor }\end{array}$ & $\begin{array}{l}\square \text { Lower level than myself } \\
\square \text { About the same level as } \\
\text { myself } \\
\square \text { Higher level than } \\
\text { myself }\end{array}$ & $\begin{array}{l}\square \text { Very close } \\
\square \text { Reasonably } \\
\text { close } \\
\square \text { Not very } \\
\text { close }\end{array}$ \\
\hline 8 & & $\begin{array}{l}\square \text { Yes } \\
\square \text { No }\end{array}$ & $\begin{array}{l}\square \text { Daily } \\
\square \text { A few times a week } \\
\square \text { 3-5 times a month } \\
\square \text { Once or twice a month } \\
\square \text { Less than once a month }\end{array}$ & $\begin{array}{l}\text { Outstanding } \\
\text { Very good } \\
\text { Good } \\
\text { Fair } \\
\text { Poor } \\
\end{array}$ & $\begin{array}{l}\square \text { Lower level than myself } \\
\square \text { About the same level as } \\
\text { myself } \\
\square \text { Higher level than } \\
\text { myself }\end{array}$ & $\begin{array}{l}\square \text { Very close } \\
\square \text { Reasonably } \\
\text { close } \\
\square \text { Not very } \\
\text { close }\end{array}$ \\
\hline
\end{tabular}

6. Do you have regular work-related interactions with individuals that are not employed by your organization? Examples may include clients, suppliers, or vendors.

$\square$ Yes (Continue)

No (Skip to Q8) 
7. Please identify up to eight work associates, individuals you work with but are not employed by your organization, e.g., clients, suppliers, vendors, etc., using their initials (e.g., John Smith = JS). You are not required to fill all eight selections: list as many or as few people as are relevant. Then, please answer the remaining questions about each individual that you name.

\begin{tabular}{|c|c|c|c|}
\hline & $\begin{array}{l}\text { Work Associate } \\
\text { Initials }\end{array}$ & $\begin{array}{l}\text { How frequently do you interact } \\
\text { with this person at work? }\end{array}$ & $\begin{array}{l}\text { Overall, how would you rate the } \\
\text { quality of your work relationship } \\
\text { with this person? }\end{array}$ \\
\hline 1 & & \begin{tabular}{|l} 
\\
$\square$ Daily \\
A few times a week \\
$\square$ 3-5 times a month \\
$\square$ Once or twice a month \\
$\square$ Less than once a month
\end{tabular} & \begin{tabular}{|l}
$\square$ Outstanding \\
$\square$ Very good \\
$\square$ Good \\
$\square$ Fair \\
$\square$ Poor \\
\end{tabular} \\
\hline 2 & & $\begin{array}{ll}\square & \text { Daily } \\
\square & \text { A few times a week } \\
\square & 3-5 \text { times a month } \\
\square & \text { Once or twice a month } \\
\square & \text { Less than once a month }\end{array}$ & $\begin{array}{ll}\square & \text { Outstanding } \\
\square & \text { Very good } \\
\square & \text { Good } \\
\square & \text { Fair } \\
\square & \text { Poor } \\
\end{array}$ \\
\hline 3 & & $\begin{array}{l}\text { Daily } \\
\square \text { A few times a week } \\
\square \text { 3-5 times a month } \\
\square \text { Once or twice a month } \\
\square \text { Less than once a month }\end{array}$ & $\begin{array}{ll} & \text { Outstanding } \\
\square \text { Very good } \\
\square \text { Good } \\
\square \text { Fair } \\
\square \text { Poor } \\
\end{array}$ \\
\hline 4 & & $\begin{array}{ll} & \text { Daily } \\
\square & \text { A few times a week } \\
\square & 3-5 \text { times a month } \\
\square & \text { Once or twice a month } \\
\square & \text { Less than once a month } \\
\end{array}$ & \begin{tabular}{|l}
$\square$ Outstanding \\
$\square$ Very good \\
$\square$ Good \\
$\square$ Fair \\
$\square$ Poor \\
\end{tabular} \\
\hline 5 & 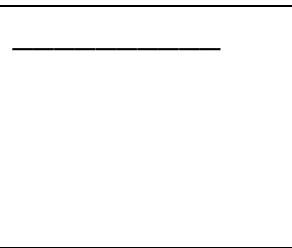 & $\begin{array}{l}\square \text { Daily } \\
\square \text { A few times a week } \\
\square \text { 3-5 times a month } \\
\square \text { Once or twice a month } \\
\square \text { Less than once a month }\end{array}$ & $\begin{array}{ll}\square & \text { Outstanding } \\
\square & \text { Very good } \\
\square & \text { Good } \\
\square & \text { Fair } \\
\square & \text { Poor }\end{array}$ \\
\hline
\end{tabular}




\begin{tabular}{|c|c|c|c|}
\hline 6 & 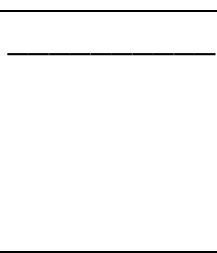 & $\begin{array}{ll}\square & \text { Daily } \\
\square & \text { A few times a week } \\
\square \text { 3-5 times a month } \\
\square \text { Once or twice a month } \\
\square \text { Less than once a month }\end{array}$ & $\begin{array}{ll}\square & \text { Outstanding } \\
\square & \text { Very good } \\
\square & \text { Good } \\
\square & \text { Fair } \\
\square & \text { Poor } \\
\end{array}$ \\
\hline 7 & & $\begin{array}{ll}\square & \text { Daily } \\
\square & \text { A few times a week } \\
\square & \text { 3-5 times a month } \\
\square & \text { Once or twice a month } \\
\square & \text { Less than once a month }\end{array}$ & $\begin{array}{l}\square \text { Outstanding } \\
\square \text { Very good } \\
\text { Good } \\
\square \text { Fair } \\
\square \text { Poor }\end{array}$ \\
\hline 8 & & $\begin{array}{ll}\square & \text { Daily } \\
\square & \text { A few times a week } \\
\square & \text { 3-5 times a month } \\
\square & \text { Once or twice a month } \\
\square & \text { Less than once a month }\end{array}$ & $\begin{array}{ll}\square & \text { Outstanding } \\
\square & \text { Very good } \\
\square & \text { Good } \\
\square & \text { Fair } \\
\square & \text { Poor }\end{array}$ \\
\hline
\end{tabular}

\begin{tabular}{|c|c|c|c|c|c|c|c|c|}
\hline 8. & $\begin{array}{l}\text { Please indicate your level of agreement with the following statements. } \\
\text { Organizational Commitment Scale } \\
\text { Meyer \& Allen (1997) } \\
\text { AC = Affective Commitment } \\
\text { CC = Continuance Commitment } \\
\text { NC = Normative Commitment }\end{array}$ & 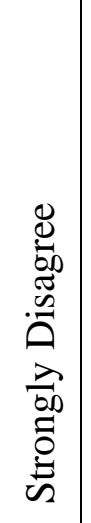 & 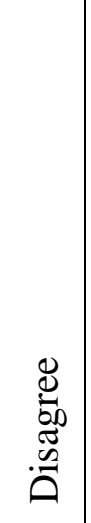 & 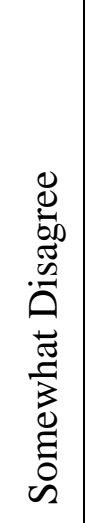 & 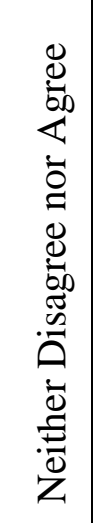 & 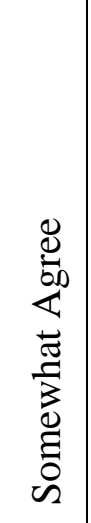 & 总 & 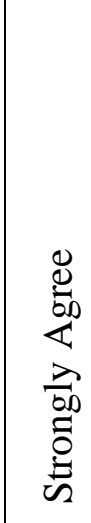 \\
\hline $\mathrm{NC}$ & $\begin{array}{l}\text { Even if it were to my advantage, I do not feel it would be right to leave my } \\
\text { organization now. }\end{array}$ & $\square$ & $\square$ & $\square$ & $\square$ & $\square$ & $\square$ & $\square$ \\
\hline $\mathrm{AC}$ & I do not feel "emotionally attached” to this organization. & & & \begin{tabular}{|l} 
\\
\end{tabular} & $\square$ & & $\square$ & \\
\hline $\mathrm{AC}$ & I do not feel a strong sense of "belonging" to my organization. & & & & & & & \\
\hline $\mathrm{NC}$ & I do not feel any obligation to remain with my current employer. & \begin{tabular}{|l} 
\\
\end{tabular} & & & & & & \\
\hline $\mathrm{AC}$ & I do not feel like "part of the family" at my organization. & $\square$ & $\square$ & $\square$ & $\square$ & $\square$ & & \\
\hline
\end{tabular}




\begin{tabular}{|c|c|c|c|c|c|c|c|c|}
\hline $\mathrm{CC}$ & I feel that I have too few options to consider leaving this organization. & & & & & & & \\
\hline $\mathrm{NC}$ & I owe a great deal to my organization. & & & & & & & \\
\hline $\mathrm{NC}$ & I really feel as if this organization’s problems are my own. & & & & & & & \\
\hline $\mathrm{AC}$ & I would be very happy to spend the rest of my career in this organization. & & & & & & & \\
\hline NC & I would feel guilty if I left my organization now. & & & 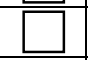 & & & & \\
\hline $\mathrm{NC}$ & $\begin{array}{l}\text { I would not leave my organization right now because I have a sense of obligation } \\
\text { to the people in it. }\end{array}$ & $\square$ & $\square$ & $\square$ & & $\square$ & & \\
\hline $\mathrm{CC}$ & $\begin{array}{l}\text { If I had not already put so much of myself into this organization, I might consider } \\
\text { working elsewhere. }\end{array}$ & $\square$ & $\square$ & $\square$ & & $\square$ & $\square$ & \\
\hline $\mathrm{CC}$ & $\begin{array}{l}\text { It would be very hard for me to leave my organization right now, even if I wanted } \\
\text { to. }\end{array}$ & $\square$ & $\square$ & $\square$ & $\square$ & $\square$ & $\square$ & \\
\hline $\mathrm{CC}$ & $\begin{array}{l}\text { One of the few negative consequences of leaving this organization would be the } \\
\text { scarcity of available alternatives. }\end{array}$ & $\square$ & $\square$ & $\square$ & & $\square$ & $\square$ & \\
\hline $\mathrm{CC}$ & $\begin{array}{l}\text { Right now, staying with my organization is a matter of necessity as much as } \\
\text { desire. }\end{array}$ & $\square$ & $\square$ & $\square$ & $\square$ & $\square$ & $\square$ & \\
\hline $\mathrm{AC}$ & This organization deserves my loyalty. & & & 5 & & & $\square$ & \\
\hline $\mathrm{AC}$ & This organization has a great deal of personal meaning for me. & & & $\square$ & & & & \\
\hline $\mathrm{CC}$ & $\begin{array}{l}\text { Too much of my life would be disrupted if I decided I wanted to leave my } \\
\text { organization now. }\end{array}$ & $\square$ & $\square$ & $\square$ & $\square$ & $\square$ & $\square$ & $\square$ \\
\hline
\end{tabular}

\begin{tabular}{|l|c|c|c|c|}
\hline $\begin{array}{l}\text { 9. Friendship Opportunity Scale } \\
\text { Nielsen, Jex \& Adams (2000) }\end{array}$ & $\begin{array}{c}\text { Strongly } \\
\text { Disagree }\end{array}$ & $\begin{array}{c}\text { Deither } \\
\text { Disagree } \\
\text { nor } \\
\text { Agree }\end{array}$ & $\begin{array}{c}\text { Agree } \\
\text { Strongly } \\
\text { Agree }\end{array}$ \\
\hline Communication among employees is encouraged by my organization & $\square$ & $\square$ & & $\square$ \\
\hline I am able to work with my coworkers to collectively solve problems & $\square$ & $\square$ & & $\square$ \\
\hline I have the opportunity to develop close friendships at my workplace & $\square$ & $\square$ & & $\square$ \\
\hline I have the opportunity to get to know my coworkers & $\square$ & $\square$ & $\square$ & $\square$ \\
\hline $\begin{array}{l}\text { In my organization, I have the chance to talk informally and visit } \\
\text { with others }\end{array}$ & $\square$ & $\square$ & $\square$ & $\square$ \\
\hline $\begin{array}{l}\text { Informal talk is tolerated by my organization as long as the work is } \\
\text { completed }\end{array}$ & $\square$ & $\square$ & $\square$ & $\square$ \\
\hline$\square$
\end{tabular}




\begin{tabular}{|c|c|c|c|c|c|c|}
\hline 10. & $\begin{array}{l}\text { Affiliation Motivation Scale } \\
\text { Hill (1987) } \\
\text { ES=Emotional Support subscale } \\
\text { PS=Positive Stimulation subscale }\end{array}$ & 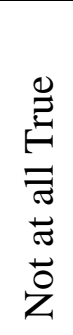 & 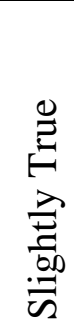 & 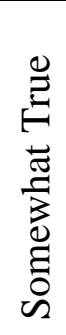 & 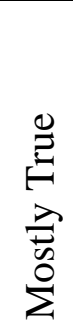 & 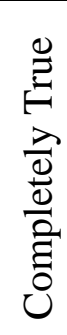 \\
\hline ES & $\begin{array}{l}\text { If I feel unhappy or kind of depressed, I usually try to be around other people to make me feel } \\
\text { better. }\end{array}$ & $\square$ & $\square$ & & $\square$ & $\square$ \\
\hline ES & $\begin{array}{l}\text { I usually have the greatest need to have other people around me when I feel upset about } \\
\text { something. }\end{array}$ & $\square$ & & & $\square$ & \\
\hline ES & One of my greatest sources of comfort when things get rough is being with other people. & $\square$ & & & $\square$ & 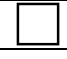 \\
\hline ES & $\begin{array}{l}\text { When I have not done very well on something that is very important to me, I can get to feeling } \\
\text { better simply by being around other people. }\end{array}$ & $\square$ & $\square$ & & $\square$ & \\
\hline ES & $\begin{array}{l}\text { During times when I have to go through something painful, I usually find that having someone } \\
\text { with me makes it less painful. }\end{array}$ & $\square$ & & & $\square$ & \\
\hline ES & $\begin{array}{l}\text { It seems like whenever something bad or disturbing happens to me I often just want to be with a } \\
\text { close, reliable friend. }\end{array}$ & $\square$ & $\square$ & & $\square$ & $\square$ \\
\hline PS & $\begin{array}{l}\text { I think being close to others, listening to them, and relating to them on a one-to-one level is one } \\
\text { of my favorite and most satisfying pastimes. }\end{array}$ & $\square$ & $\square$ & & $\square$ & $\square$ \\
\hline PS & $\begin{array}{l}\text { Just being around others and finding out about them is one of the most interesting things I can } \\
\text { think of doing. }\end{array}$ & $\square$ & & & $\square$ & $\square$ \\
\hline PS & I feel like I have really accomplished something valuable when I am able to get close to someone. & $\square$ & $\square$ & & $\square$ & \begin{tabular}{|l} 
\\
\end{tabular} \\
\hline PS & $\begin{array}{l}\text { One of the most enjoyable things I can think of that I like to do is just watching people and seeing } \\
\text { what they are like. }\end{array}$ & 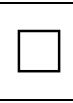 & 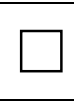 & & $\square$ & L \\
\hline PS & I would find it very satisfying to be able to form new friendships with whomever I liked. & & & & & \\
\hline PS & I seem to get satisfaction from being with others more than a lot of other people do. & & & & & \\
\hline PS & I think it would be satisfying if I could have very close friendships with quite a few people. & $L$ & $\square$ & & $\square$ & \\
\hline PS & $\begin{array}{l}\text { The main thing I like about being around other people is the warm glow I get from contact with } \\
\text { them. }\end{array}$ & $\square$ & $\square$ & & $\square$ & \\
\hline PS & I think I get satisfaction out of contact with others more than most people realize. & & & & & \\
\hline
\end{tabular}




\begin{tabular}{|c|c|c|c|c|c|c|}
\hline $\begin{array}{l}\text { 11. Work Investments } \\
\text { Assume that you are thinking about leaving your current } \\
\text { job. Please indicate how likely each of the following } \\
\text { work characteristics would be to keep you from leaving } \\
\text { your job. If a particular work characteristic does not apply } \\
\text { to you (i.e., you do not have or use that characteristic), } \\
\text { please mark "N/A." }\end{array}$ & $\begin{array}{c}\text { N/A } \\
\text { (Do not have or } \\
\text { do not use } \\
\text { characteristic) }\end{array}$ & 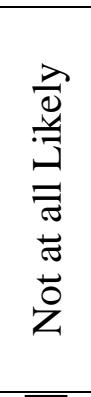 & 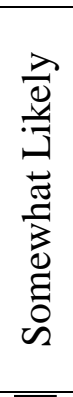 & 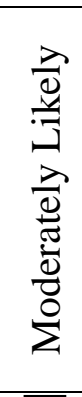 & 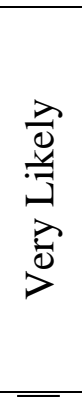 & 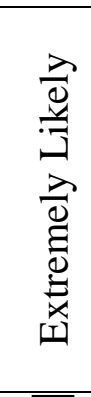 \\
\hline Pay & & & $\square$ & L & $\square$ & $\square$ \\
\hline Amount of vacation time & & & & & & \\
\hline Health insurance/benefits & & & & & & \\
\hline Life insurance & & & & & & 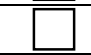 \\
\hline Retirement Plan (401K) & & & & & & 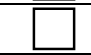 \\
\hline Pension & & & & & & $\square$ \\
\hline Company-paid benefits (e.g., cell phone, car, computer) & & & & & & $\square$ \\
\hline Seniority & & & & & & 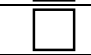 \\
\hline Job security & & & & & & 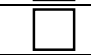 \\
\hline Flex-time & & & & & & 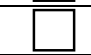 \\
\hline Education/tuition benefits & & & & & & \\
\hline Transferability of your skills to another job & & & & & & $\bar{E}$ \\
\hline Transferability of your education to another job & & & & & & \\
\hline Commute time & & & & & & \\
\hline Availability of other job opportunities & & & $\square$ & $\mathrm{E}$ & $\square$ & $\square$ \\
\hline Attractiveness of other job opportunities & & & $\square$ & & & $\square$ \\
\hline Ability to relocate & & & $\square$ & & $\square$ & $\square$ \\
\hline
\end{tabular}


12. Abridged JIG (Stanton et al., 2002)

JOB IN GENERAL

Think of your job in general. All in all, what is it like most of the time? For each of the following words or phrases, choose one:

\begin{tabular}{|l|r|r|r|}
\hline & Yes & No & ? \\
\hline Good & $\square$ & $\square$ & $\square$ \\
\hline Undesirable & $\square$ & $\square$ & $\square$ \\
\hline Better than most & $\square$ & $\square$ & $\square$ \\
\hline Disagreeable & $\square$ & $\square$ & $\square$ \\
\hline Makes me content & $\square$ & $\square$ & $\square$ \\
\hline Excellent & $\square$ & $\square$ & $\square$ \\
\hline Enjoyable & $\square$ & $\square$ & $\square$ \\
\hline Poor & $\square$ & $\square$ & $\square$ \\
\hline
\end{tabular}

\begin{tabular}{|c|c|c|c|c|c|c|c|}
\hline $\begin{array}{l}\text { 13. Please indicate how much you agree with the following statements. } \\
\text { Intentions to Quit } \\
\text { Crossley et al. (2002) }\end{array}$ & 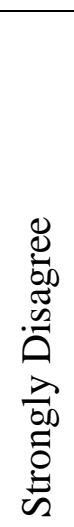 & 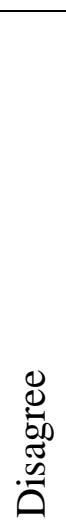 & 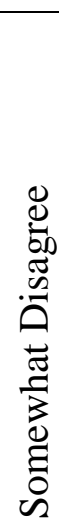 & 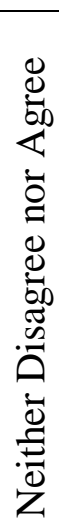 & 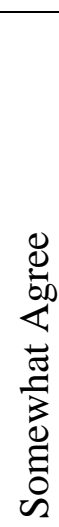 & 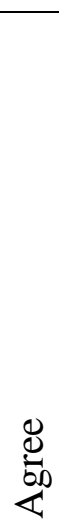 & 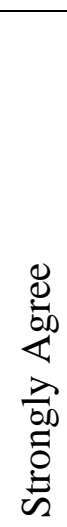 \\
\hline I plan to leave this organization in the next little while & & $\square$ & & $\square$ & $\square$ & 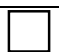 & $\square$ \\
\hline I will quit this company as soon as possible & & & & & & & L \\
\hline I do not plan on leaving this organization soon & & & & & & & 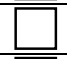 \\
\hline I may leave this organization before too long & & & & & 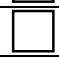 & 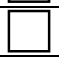 & $\square$ \\
\hline I plan on staying at this company as long as possible & & & & & & & $\square$ \\
\hline I intend to leave this organization soon & & & & & & & \\
\hline
\end{tabular}




\begin{tabular}{|c|c|c|c|c|c|c|}
\hline $\begin{array}{l}\text { 14. The following questions concern your beliefs about jobs in general. They do not refer } \\
\text { only to your present job. }\end{array}$ & 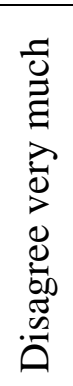 & 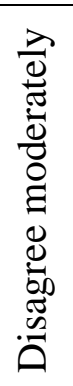 & 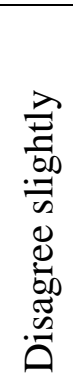 & 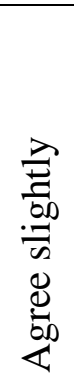 & 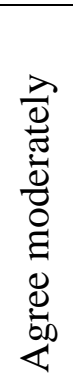 & 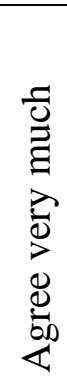 \\
\hline A job is what you make of it & & & & & & \\
\hline On most jobs, people can pretty much accomplish whatever they set out to accomplish & & & & & & \\
\hline If you know what you want out of a job, you can find a job that gives it to you & & & & & & \\
\hline $\begin{array}{l}\text { If employees are unhappy with a decision made by their boss, they should do something } \\
\text { about it }\end{array}$ & & & & & & \\
\hline Getting the job you want is mostly a matter of luck & & & & & & \\
\hline Making money is primarily a matter of good fortune & & & & & & \\
\hline Most people are capable of doing their jobs well if they make the effort & & & & & & \\
\hline In order to get a really good job you need to have family members or friends in high places & & & & & & \\
\hline Promotions are usually a matter of good fortune & & & & & $\bar{L}$ & \\
\hline $\begin{array}{l}\text { When it comes to landing a really good job, who you know is more important than what } \\
\text { you know }\end{array}$ & & & $\square$ & 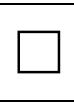 & $\square$ & $\square$ \\
\hline Promotions are given to employees who perform well on their jobs & & & & & & \\
\hline To make a lot of money you have to know the right people & & & & & & \\
\hline It takes a lot of luck to be an outstanding employee on most jobs & & & & & & \\
\hline People who perform their jobs well generally get rewarded for it & & & & & & \\
\hline Most employees have more influence on their supervisors than they think they do & & & & & 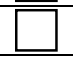 & \\
\hline $\begin{array}{l}\text { The main difference between people who make a lot of money and people who make little } \\
\text { money is luck }\end{array}$ & $\square$ & $\square$ & $\square$ & $\square$ & $\square$ & $\square$ \\
\hline
\end{tabular}




\begin{tabular}{|c|c|c|c|c|c|c|c|c|c|}
\hline $\begin{array}{l}\text { 15. Please use this list of common characteristics to } \\
\text { describe yourself as accurately as possible. When making } \\
\text { your ratings, describe yourself as you are at the present } \\
\text { time, not as you wish to be in the future. } \\
\text { Big-Five Personality Characteristics } \\
\text { Goldberg's Mini-Markers } \\
\text { (Saucier, 1994) }\end{array}$ & 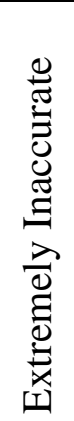 & 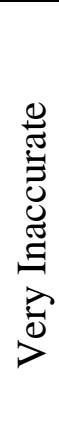 & 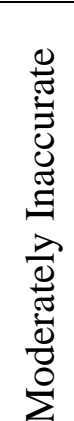 & 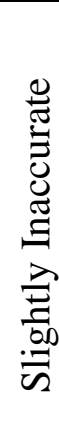 & $\begin{array}{l}\bar{Z} \\
\stackrel{Z}{Z} \\
Z\end{array}$ & 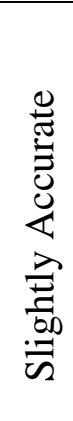 & 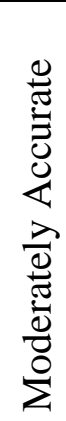 & 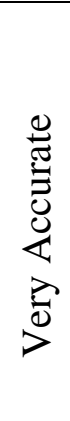 & 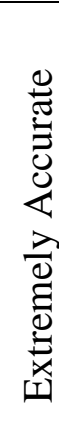 \\
\hline Bashful & 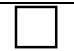 & & 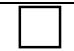 & & $\square$ & $\square$ & $\square$ & $\square$ & $\square$ \\
\hline Bold & & & 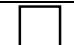 & & $\square$ & $\square$ & 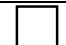 & 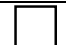 & 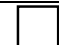 \\
\hline Cold & & & 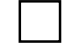 & - & $\square$ & $\square$ & $\square$ & $\square$ & 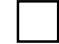 \\
\hline Cooperative & & & 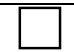 & & 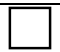 & 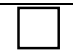 & 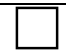 & & \\
\hline Energetic & & & 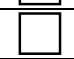 & & 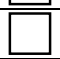 & 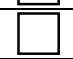 & 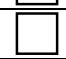 & 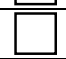 & 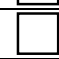 \\
\hline Extraverted & & & 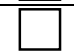 & & 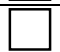 & 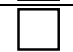 & 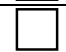 & 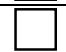 & $\bar{L}$ \\
\hline Harsh & & & 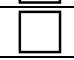 & & $\square$ & 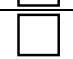 & 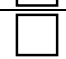 & 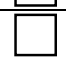 & 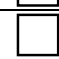 \\
\hline Kind & & & 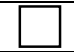 & & $\square$ & $\square$ & 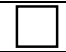 & $\square$ & 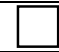 \\
\hline Quiet & & & 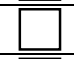 & & $\bar{~}$ & 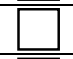 & 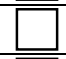 & 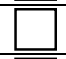 & 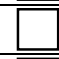 \\
\hline Rude & & & 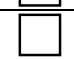 & & 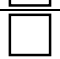 & 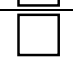 & 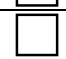 & 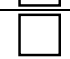 & 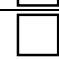 \\
\hline Shy & & & 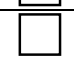 & & 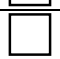 & 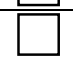 & 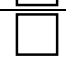 & $\underline{E}$ & 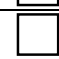 \\
\hline Sympathetic & & & 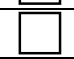 & & 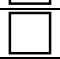 & 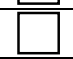 & 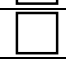 & 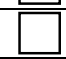 & 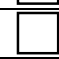 \\
\hline Talkative & & & & & & $\bar{~}$ & & & \\
\hline Unsympathetic & & & $\square$ & & $\square$ & $\square$ & 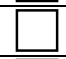 & 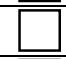 & 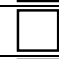 \\
\hline Warm & & & $\square$ & & $\square$ & $\square$ & 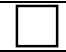 & 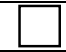 & 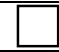 \\
\hline Withdrawn & $D_{0}$ & - & $\square$ & & $\mid$ & $\square$ & " & & 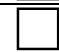 \\
\hline
\end{tabular}


16. What is your gender?

17. What is your age (in years)?

18. What is the highest level of education that you have completed?

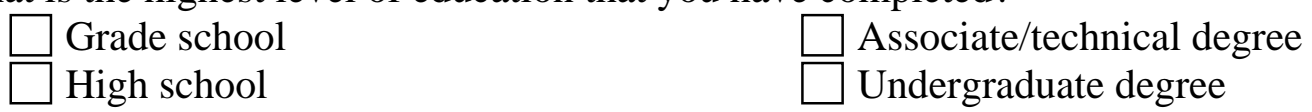

$\square$ Graduate/professional degree

19. What is your race/ethnicity?

$\square$ African American/Black Asian/Pacific Islander
Caucasian/White

Hispanic/Latino $\square$ Native American
$\square$ Other

20. What is your current employment status?

Full time

Part time

21. On average, how many hours do you work per week?
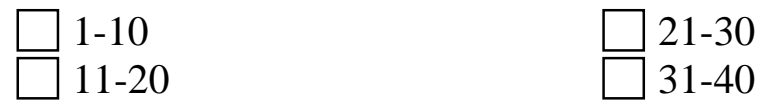

More than 60

22. How long have you been with your current organization? Using the drop down menus provided, please indicate the number of years and months. For example, if you have been with your organization for $1 \frac{1 / 2}{2}$ years, you will report Years=1 and Months=6.

\section{Years $\underline{1}$ Months $\underline{1}$}

23. How long have you been IN YOUR CURRENT POSITION with your current organization? Using the drop down menus provided, please indicate the number of years and months. For example, if you have been in your current position with your current organization for 11 months, you will report Years=0 and Months=11.

\section{Years $\underline{1}$ Months $\underline{1}$}

24. On a scale of $1-5,1=$ lowest, $5=$ highest, at what level would you rank your position within your organization?
$\square 1$ 
Table 1

Descriptions of Participating Organizations

\begin{tabular}{|c|c|c|c|c|c|c|c|}
\hline Organization & $\begin{array}{l}\text { Number of } \\
\text { Participants }\end{array}$ & $\begin{array}{c}\text { Percent of } \\
\text { Total Sample }\end{array}$ & $\begin{array}{c}\text { Response } \\
\text { Rate }\end{array}$ & $\begin{array}{c}\text { Organization } \\
\text { Type }\end{array}$ & $\begin{array}{c}\text { Data Collection } \\
\text { Method }\end{array}$ & $\begin{array}{c}\text { Work Computer } \\
\text { Access Type }\end{array}$ & $\begin{array}{l}\text { Organization } \\
\text { Description }\end{array}$ \\
\hline 1 & 88 & $18.7 \%$ & $36.7 \%$ & Private & Internet & Personal & Retail - Food \\
\hline 2 & 59 & $12.6 \%$ & $46.1 \%$ & Educational & Internet & Personal & $\begin{array}{l}\text { Private University } \\
\text { Staff Department }\end{array}$ \\
\hline 3 & 40 & $8.5 \%$ & $42.6 \%$ & Private & Internet & Personal, Common & Financial Services \\
\hline 4 & 69 & $14.7 \%$ & $45.7 \%$ & Governmental & Internet, Paper & Personal & City Staff \\
\hline 5 & 122 & $26.0 \%$ & $35.7 \%$ & Governmental & Internet & Personal, Common & $\begin{array}{c}\text { Government } \\
\text { Service Agency }\end{array}$ \\
\hline 6 & 92 & $19.6 \%$ & $23.1 \%$ & Governmental & Internet & Personal, Common & $\begin{array}{c}\text { Government } \\
\text { Service Agency }\end{array}$ \\
\hline
\end{tabular}


Table 2

Means, Standard Deviations, and Pearson Intercorrelations of All Continuous and Dichotomous Variables

\begin{tabular}{|c|c|c|c|c|c|c|c|c|c|c|c|}
\hline & Variable & $M$ & $S D$ & 1 & 2 & 3 & 4 & 5 & 6 & 7 & 8 \\
\hline \multirow[t]{2}{*}{1.} & Continuance & 4.09 & 1.15 & - & & & & & & & \\
\hline & Commitment & & & & & & & & & & \\
\hline \multirow[t]{3}{*}{2.} & Continuance & 4.15 & 1.39 & $.86^{* *}$ & - & & & & & & \\
\hline & Commitment - & & & & & & & & & & \\
\hline & Alternatives & & & & & & & & & & \\
\hline \multirow[t]{3}{*}{3.} & Continuance & 4.02 & 1.31 & $.84 * *$ & $.44^{* *}$ & - & & & & & \\
\hline & Commitment - & & & & & & & & & & \\
\hline & Personal Sacrifice & & & & & & & & & & \\
\hline 4. & Affective Commitment & 4.70 & 1.24 & .03 & $-.12 *$ & $.18 * *$ & - & & & & \\
\hline \multirow[t]{2}{*}{5.} & Normative & 4.30 & 1.37 & $.14^{* *}$ & -.06 & $.31 * *$ & $.75^{* *}$ & - & & & \\
\hline & Commitment & & & & & & & & & & \\
\hline 6. & Intent to Quit & 2.69 & 1.52 & $-.17 * *$ & -.06 & $-.23 * *$ & $-.56 * *$ & $-.56^{* *}$ & - & & \\
\hline 7. & Job Satisfaction & 2.39 & .70 & -.01 & $-.09 *$ & .07 & $.63^{* *}$ & $.51 * *$ & $-.53 * *$ & - & \\
\hline 8. & Friendship Opportunity & 3.94 & .59 & .08 & .03 & $.11^{*}$ & $.35 * *$ & $.26 * *$ & $-.34 * *$ & $.41^{* *}$ & \\
\hline
\end{tabular}


Variable

9. Need for Affiliation

10. Need for Affiliation Emotional Support

11. Need for Affiliation -

2.83

.89

.07

.01

$.10 *$

Positive Stimulation

12. Other Work

$$
2.80
$$

.94

$.22 * *$

Investments

13. Work Alternatives

124

14. Locus of Control

4.49

15. Extraversion

6.06

16. Agreeableness

$7.28 \quad 1.08$

17. Network Relationship

Quality

18. Network Relationship

Quality - Primary

Supervisor

$\begin{array}{lllllll}2 & 3 & 4 & 5 & 6 & 7 & 8\end{array}$

$9 \quad 10$




\begin{tabular}{|c|c|c|c|c|c|c|c|c|c|c|c|c|c|}
\hline & Variable & $M$ & $S D$ & 1 & 2 & 3 & 4 & 5 & 6 & 7 & 8 & 9 & 10 \\
\hline \multirow[t]{2}{*}{19.} & Network Relationship & 3.65 & .63 & .01 & -.03 & .05 & $.25 * *$ & $.13^{* *}$ & $-.20 * *$ & $.21 * *$ & $.32 * *$ & .06 & .05 \\
\hline & Quality - Coworkers & & & & & & & & & & & & \\
\hline \multirow[t]{2}{*}{20.} & Network Relationship & 3.71 & .64 & -.13 & $-.19 *$ & -.02 & .14 & .08 & -.07 & $.21 * *$ & .13 & .03 & -.05 \\
\hline & Quality - Subordinates & & & & & & & & & & & & \\
\hline \multirow[t]{2}{*}{21.} & Network Relationship & 4.07 & .61 & .06 & .04 & .07 & .07 & .01 & $-.11^{*}$ & $.12^{*}$ & $.28 * *$ & .05 & .00 \\
\hline & Quality - Friends & & & & & & & & & & & & \\
\hline \multirow[t]{3}{*}{22.} & Network Relationship & 3.75 & .68 & .04 & -.03 & .10 & .13 & .08 & -.04 & .03 & $.16^{*}$ & .12 & .04 \\
\hline & Quality - Work & & & & & & & & & & & & \\
\hline & Associates & & & & & & & & & & & & \\
\hline 23. & Network Size & 12.71 & 5.48 & .02 & $-.09 *$ & $.13^{* *}$ & $.22 * *$ & $.22 * *$ & $-.11^{*}$ & .02 & .07 & $.17 * *$ & $.13 * *$ \\
\hline \multirow[t]{2}{*}{24.} & Network Size - & 6.43 & 1.88 & .06 & -.03 & $.14 * *$ & .06 & $.10^{*}$ & -.06 & -.07 & .08 & .05 & .03 \\
\hline & Coworkers & & & & & & & & & & & & \\
\hline \multirow[t]{2}{*}{25.} & Network Size - & 5.25 & 2.52 & .03 & -.05 & .11 & .09 & .14 & $-.15 *$ & -.10 & -.04 & $.25 * *$ & $.23 * *$ \\
\hline & Subordinates & & & & & & & & & & & & \\
\hline 26. & Network Size - & 4.34 & 2.32 & .04 & -.06 & $.13 * *$ & $.19 * *$ & $.18 * *$ & $-.12 *$ & .06 & $.12 *$ & $.22 * *$ & $.14 * *$ \\
\hline
\end{tabular}




\begin{tabular}{|c|c|c|c|c|c|c|c|c|c|c|c|c|c|}
\hline & Variable & $M$ & $S D$ & 1 & 2 & 3 & 4 & 5 & 6 & 7 & 8 & 9 & 10 \\
\hline \multirow[t]{2}{*}{27.} & Network Size - Work & 4.09 & 2.32 & -.04 & -.13 & .06 & $.20 * *$ & $.21^{* *}$ & -.12 & .12 & -.01 & $.17 *$ & .10 \\
\hline & \multicolumn{13}{|l|}{ Associates } \\
\hline 28. & Network Interaction & 4.17 & .62 & .03 & .09 & -.05 & -.06 & $-.09 *$ & .03 & -.05 & .07 & -.04 & -.03 \\
\hline \multirow[t]{2}{*}{29.} & Network Interaction - & 4.55 & .78 & -.03 & .01 & -.07 & .01 & .01 & -.02 & -.04 & .08 & .02 & .04 \\
\hline & Primary Supervisor & & & & & & & & & & & & \\
\hline \multirow[t]{2}{*}{30.} & Network Interaction - & 4.25 & .77 & $.10^{*}$ & $.14^{* *}$ & .03 & -.04 & -.03 & -.03 & -.04 & .08 & -.01 & .03 \\
\hline & Coworkers & & & & & & & & & & & & \\
\hline \multirow[t]{2}{*}{31.} & Network Interaction - & 4.51 & .72 & -.02 & -.01 & -.03 & -.02 & -.03 & .11 & -.10 & .03 & .03 & .02 \\
\hline & Subordinates & & & & & & & & & & & & \\
\hline \multirow[t]{2}{*}{32.} & Network Interaction - & 4.22 & .79 & .01 & .02 & .00 & .03 & .02 & .00 & -.03 & .08 & .07 & .05 \\
\hline & Friends & & & & & & & & & & & & \\
\hline \multirow[t]{2}{*}{33.} & Network Interaction - & 2.72 & 1.10 & .11 & .06 & .13 & .01 & .06 & .00 & -.09 & .02 & -.03 & .02 \\
\hline & Work Associates & & & & & & & & & & & & \\
\hline 34. & Relative Network & 2.02 & .39 & -.02 & .05 & $-.10 *$ & -.07 & -.06 & .01 & -.03 & -.04 & .00 & -.01 \\
\hline
\end{tabular}




\begin{tabular}{|c|c|c|c|c|c|c|c|c|c|c|c|c|c|}
\hline & Variable & $M$ & $S D$ & 1 & 2 & 3 & 4 & 5 & 6 & 7 & 8 & 9 & 10 \\
\hline \multirow[t]{2}{*}{35.} & Relative Network & 2.05 & .41 & -.02 & .05 & $-.10^{*}$ & -.08 & -.07 & .01 & -.04 & -.03 & .00 & .00 \\
\hline & Status - Coworkers & & & & & & & & & & & & \\
\hline \multirow[t]{2}{*}{36.} & Relative Network & 1.95 & .48 & -.04 & .00 & -.07 & -.03 & -.02 & -.02 & .01 & -.02 & .04 & .01 \\
\hline & Status - Friends & & & & & & & & & & & & \\
\hline 37. & Friendship Intimacy & 2.11 & .45 & $.11 *$ & $.11^{*}$ & .08 & -.02 & -.01 & .05 & -.03 & $.11^{*}$ & .08 & .04 \\
\hline 38. & Organizational Tenure & 146.92 & 103.92 & $.23 * *$ & $.15^{* *}$ & $.24 * *$ & $.15^{* *}$ & $.12 *$ & -.08 & .04 & -.03 & .03 & .02 \\
\hline 39. & Job Tenure & 91.85 & 76.46 & $.22 * *$ & $.16^{* *}$ & $.21 * *$ & .03 & .03 & -.04 & .00 & -.07 & .00 & -.02 \\
\hline 40. & Gender & 1.64 & .48 & $.15^{* *}$ & $.16^{* *}$ & .09 & .01 & .01 & $-.10 *$ & .00 & -.02 & $.11^{*}$ & $.13^{* *}$ \\
\hline 41. & Age & 42.79 & 10.90 & .06 & .04 & .06 & $.18 * *$ & $.18^{* *}$ & $-.14^{* *}$ & $.11^{*}$ & -.06 & .07 & .02 \\
\hline 42. & Job Level & 3.02 & .96 & -.06 & $-.13 * *$ & .04 & $.25 * *$ & $.31^{*}$ & $-.17 * *$ & $.22 * *$ & $.09 *$ & $.11^{*}$ & $.12 *$ \\
\hline 43. & Employment Status & 1.14 & .35 & -.09 & -.06 & $-.10 *$ & $-.11 *$ & $-.11^{*}$ & .06 & $-.09 *$ & -.07 & .02 & .01 \\
\hline 44. & Supervisory Status & 1.63 & .49 & .07 & $.11^{*}$ & .00 & $-.10 *$ & $-.12 *$ & .01 & -.03 & -.03 & -.02 & -.01 \\
\hline 45. & Work Associate & 1.58 & .50 & .05 & .08 & .01 & $-.12 *$ & $-.10 *$ & .00 & .00 & .02 & -.04 & -.03 \\
\hline
\end{tabular}

Contact 
Variable 11

12

13

14

15

\section{Need for Affiliation - \\ Positive Stimulation}

12. Other Work

$.09 * \quad-$

Investments

13. Work Alternatives

$.03 \quad .58 * * \quad-$

14. Locus of Control

$.13 * * \quad .01 \quad-.03$

15. Extraversion

$.15^{* *} \quad .06 \quad-.03$

16. Agreeableness

$\begin{array}{llllll}.24 * * & .05 & -.03 & .23^{* *} & .16^{* *} & -\end{array}$

17. Network Relationship

$\begin{array}{llllll}.11^{*} & .00 & -.06 & .15^{* *} & .20^{* *} & .28^{* *}\end{array}$

Quality

18. Network Relationshi

$.07 \quad .06$

Quality - Primary

Supervisor

19. Network Relationship .06

$\begin{array}{lll}.02 \quad-.05 \quad \text {.0 } & .09\end{array}$

Quality - Coworkers 


11

$12 \quad 13 \quad 14$

15

20. Network Relationship

.08

$\begin{array}{lllllllllll}-.04 & -.12 & .11 & .09 & .16^{*} & .73^{* *} & .20 * & .43^{* *} & \text { - }\end{array}$

Quality - Subordinates

21. Network Relationship

.08

$.03 \quad-.01$

.08

$.13^{* *}$

$\begin{array}{llllll}.16^{* *} & .71^{* *} & .25 * * & .59 * * & .47 * * & -\end{array}$

Quality - Friends

22. Network Relationship

$\begin{array}{llll}.15^{*} & -.05 & -.16^{*} \quad .07\end{array}$

.06

$\begin{array}{lllllll}.23 * * & .68 * * & .12 & .35 * * & .42 * * & .42 * * & -\end{array}$

Quality - Work

Associates

23. Network Size

$\begin{array}{cccccccccccc}.17^{* *} & .15^{* *} & .01 & .17^{* *} & .21^{* *} & .14^{* *} & .04 & .05 & -.01 & .03 & -.06 & -.01 \\ .06 & .02 & -.00 & .01 & .06 & .02 & -.03 & .04 & -.06 & .03 & -.07 & .01\end{array}$

24. Network Size -

Coworkers

25. Network Size -

$$
.23^{* *}
$$

.13

02
Subordinates

26. Network Size -

$$
.25 * *
$$

$.06 \quad-.05$

$.17^{*}$

27. Network Size - Work

$.19 * *$

$-.01-.07$

13

$.08 \quad .21^{* *} \quad .17^{*}$

.02

.10

$.13 \quad .02 \quad .11$

Associates 


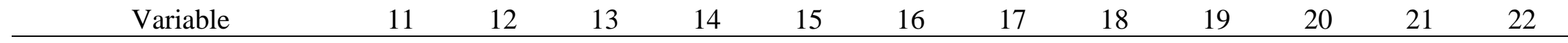

28. Network Interaction $\quad \begin{array}{rlllllllllllllll}0.05 & -.04 & -.01 & -.13^{* *} & -.04 & -.10^{*} & .05 & .05 & .05 & .00 & .06 & .00\end{array}$

29. Network Interaction $-\quad \begin{array}{lllllllllllllll}0 & .01 & .04 & .02 & -.02 & .02 & -.07 & .00 & .15^{* *} & -.03 & -.02 & -.02 & -.14\end{array}$ Primary Supervisor

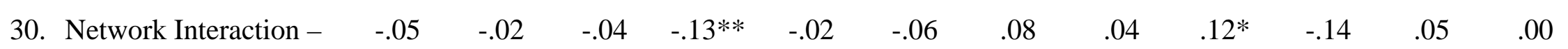
Coworkers

31. Network Interaction $-\quad \begin{array}{lllllllllllllllllllllllll} & .03 & .02 & .05 & .02 & -.09 & -.03 & .03 & -.01 & -.01 & .12 & .02 & .01\end{array}$ Subordinates

32. Network Interaction $-\quad \begin{array}{lllllllllllllll}.07 & -.06 & -.02 & -.05 & -.02 & -.10^{*} & .06 & .01 & .07 & .03 & .11^{*} & .10\end{array}$ Friends

33. Network Interaction $-\quad \begin{array}{lllllllllllllll} & -.06 & .00 & -.05 & .00 & .00 & -.09 & .03 & -.05 & .05 & -.23^{*} & .02 & .00\end{array}$ Work Associates

34. Relative Network

$\begin{array}{llllllllllll}.01 & -.11 * & -.07 & -.01 & -.08 & .04 & .06 & .06 & .03 & .04 & -.02 & .02\end{array}$
Status

35. Relative Network

$\begin{array}{llllllllllllll}.01 & -.08 & -.06 & .01 & -.07 & .05 & .05 & .07 & .01 & .06 & -.03 & -.01\end{array}$

Status - Coworkers 
Variable

36. Relative Network

Status - Friends

38. Organizational Tenure

39. Job Tenure

40. Gender

41. Age

42. Job Level

43. Employment Status

44. Supervisory Status

45. Work Associate

Contact

\begin{tabular}{llllllllllll}
11 & 12 & 13 & 14 & 15 & 16 & 17 & 18 & 19 & 20 & 21 & 22 \\
\hline
\end{tabular}

$\begin{array}{llllllllllll}.05 & -.11 * & -.08 & -.06 & -.05 & .03 & .11^{*} & .07 & .09 & .00 & .02 & .04\end{array}$

$\begin{array}{cccccccccccc}.09 & .05 & .03 & -.01 & .10 & .12^{*} & .26 * * & .05 & .19 * * & .11 & .42 * * & .19 * \\ .03 & .15 * * & -.12 * & -.06 & .08 & .02 & .01 & -.06 & -.01 & .01 & .03 & .08 \\ .02 & .09 & -.12^{*} & -.11^{*} & .04 & -.01 & .00 & -.12 * & .00 & .10 & .08 & .16^{*} \\ .08 & .11 * & .04 & .01 & .01 & .17 * * & -.01 & .00 & -.02 & .09 & .01 & -.14 \\ .10 * & .06 & -.13^{* *} & .04 & .00 & .16^{* *} & -.02 & -.02 & -.02 & .04 & -.04 & .12 \\ .10 * & .14 * * & .01 & .20 * * & .01 & .04 & .00 & .05 & -.05 & .02 & -.05 & .02 \\ .02 & -.15 * * & -.05 & -.06 & -.02 & .00 & -.01 & .00 & .01 & .01 & -.06 & -.01 \\ -.02 & -.10 * & -.02 & -.13 * * & -.14 * * & -.08 & .05 & .02 & .07 & \mathrm{a} & .02 & .04 \\ -.04 & -.04 & -.03 & -.07 & -.01 & -.04 & -.03 & -.01 & -.00 & -.05 & -.01 & \mathrm{a}\end{array}$




24

25

23. Network Size

24. Network Size $.50 * * \quad-$

\section{Coworkers}

25. Network Size -

$.60 * * \quad .15^{*}$

Subordinates

26. Network Size -

$.55^{* *} \quad .35^{* *} \quad .24 * * \quad-$

Friends

27. Network Size - Work $\quad .67^{* *} \quad .27^{* *} \quad .15 \quad .50^{* *} \quad$ -

Associates

28. Network Interaction $\quad \begin{array}{lllllll}-.22 * * & -.02 & .04 & -.11 * & -.39 * * & -\end{array}$

29. Network Interaction $-\quad \begin{array}{llllllll}-01 & .07 & -.02 & .05 & -.02 & .46^{* *} & -\end{array}$

Primary Supervisor

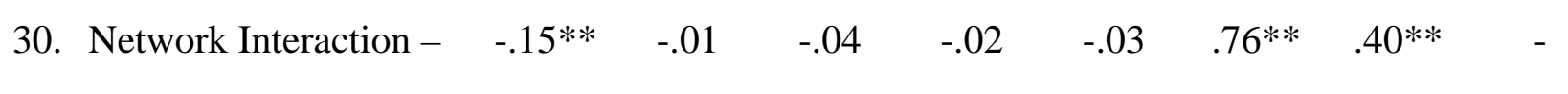

Coworkers

31. Network Interaction $-\quad \begin{array}{lllllllllll} & .04 & .00 & .04 & .10 & .08 & .55^{* *} & .15 & .26^{* *} & \text { - }\end{array}$

Subordinates 


24

$25 \quad 26$

32. Network Interaction $-\quad-.15^{* *} \quad \begin{array}{llllllllll} & .05 & -.05 & -.03 & .00 & .58^{* *} & .24^{* *} & .49^{* *} & .25^{* *} & -\end{array}$

\section{Friends}

33. Network Interaction -

$\begin{array}{llllllllllll}.00 & .03 & .09 & .06 & .21 * * & -.48 * * & .04 & .24 * * & -.02 & .20 * & -\end{array}$

Work Associates

34. Relative Network

$\begin{array}{lllllll}-.22 * * & -.05 & -.13 & -.04 & -.07 & .04\end{array}$

.09

$.05 \quad-.14$

$.03 \quad .02$

Status

35. Relative Network

$$
\begin{array}{llll}
-.16 * * & -.06 & -.04 & -.04
\end{array}
$$

.04

$-.10$

$.00 \quad .07$

$-.02$

$-.08$

$.01 \quad .03 \quad .92 * *$

Status - Coworkers

36. Relative Network

$$
\begin{array}{lll}
-.25 * * & -.10 * & -.14
\end{array}
$$

.03

$$
-.05
$$

37. Friendship Intimacy

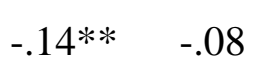

39. Job Tenure

$\begin{array}{llll}.23 * * & .09 \quad .07 \quad .09\end{array}$

$\begin{array}{lll}.07 & .03 & -.08\end{array}$

40. Gender

$\begin{array}{llll}.01 & .08 \quad .04 \quad .04\end{array}$

41. Age

$\begin{array}{llll}.18 * * & -.02 & .05 & .01\end{array}$

42. Job Level

$.26^{* *} \quad .13^{* *} \quad .02 \quad .16^{* *}$ 


\begin{tabular}{|c|c|c|c|c|c|c|c|c|c|c|c|c|c|}
\hline & Variable & 23 & 24 & 25 & 26 & 27 & 28 & 29 & 30 & 31 & 32 & 33 & 34 \\
\hline 43. & Employment Status & $-.16^{* *}$ & .01 & -.15 & -.03 & $-.15^{*}$ & -.04 & .00 & -.02 & $-.16^{*}$ & -.06 & $.17^{*}$ & $.12^{* *}$ \\
\hline 44. & Supervisory Status & $-.42 * *$ & .01 & -.08 & -.00 & .04 & $.09 *$ & .09 & $.27 *$ & $\mathrm{a}$ & $.11^{*}$ & $.28 * *$ & $.37 * *$ \\
\hline 45. & Work Associate & $-.50 * *$ & -.08 & .03 & $-.14 * *$ & -.07 & $.23 * *$ & -.02 & .02 & -.06 & .04 & $\mathrm{a}$ & $.16^{* *}$ \\
\hline
\end{tabular}


35. Relative Network

Status - Coworkers

36. Relative Network

$.58 * * \quad-$

Status - Friends

37. Friendship Intimacy

$.05 \quad .12 * \quad-$

38. Organizational Tenure

39. Job Tenure

$\begin{array}{lll}-.18 * * & -.16^{* *} \quad .09\end{array}$

40. Gender

$\begin{array}{lllll}-.16 * * & -.04 & .08 & .64 * * \quad-\end{array}$

41. Age $\begin{array}{llllll}.17^{* *} & .01 & .16^{* *} & .02 & .04 & -\end{array}$

42. Job Level $\begin{array}{lllllll}-.01 & -.02 & -.02 & .49 * * & .39 * * & .00 & -\end{array}$

43. Employment Status $\begin{array}{llllllll}-.30^{* *} & -.30 * * & -.11^{*} & .19^{* *} & .11^{*} & -.13^{* *} & .14^{* *} & -\end{array}$

44. Supervisory Status $\begin{array}{lllll}.12 * & .16^{* *} \quad .01 & -.16^{* *} & -.06\end{array}$ $.12 * \quad-.14^{* *}-.14^{* *} \quad-$

45. Work Associate $\begin{array}{lllllllll}.30 * * & .40 * * & .13^{* *} & -.18^{* *} & -.10^{*} & .08 & -.25^{* *} & -.31 * * & .20 * *\end{array}$ $\begin{array}{lllll}.16^{* *} & .10^{*} \quad .11^{*}-.13^{* *} \quad-.03\end{array}$

\section{Contact}

${ }^{*} p<.05{ }^{* *} p<.01{ }^{\text {a }}$ The value of one or both variables is a constant; therefore, no correlation can be computed. 
Table 3

Means and Standard Deviations of All Continuous and Dichotomous Variables by Organization

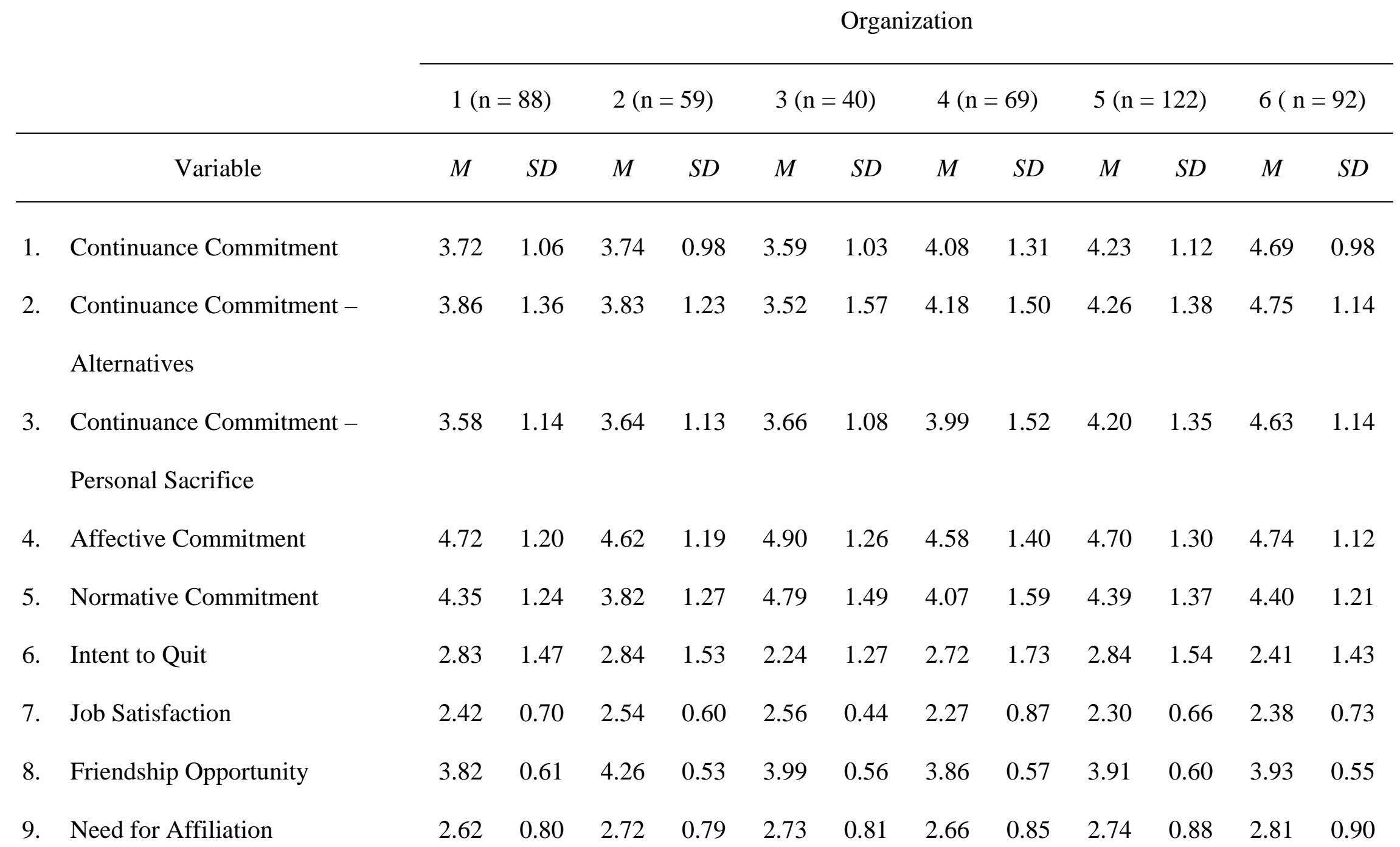


Organization

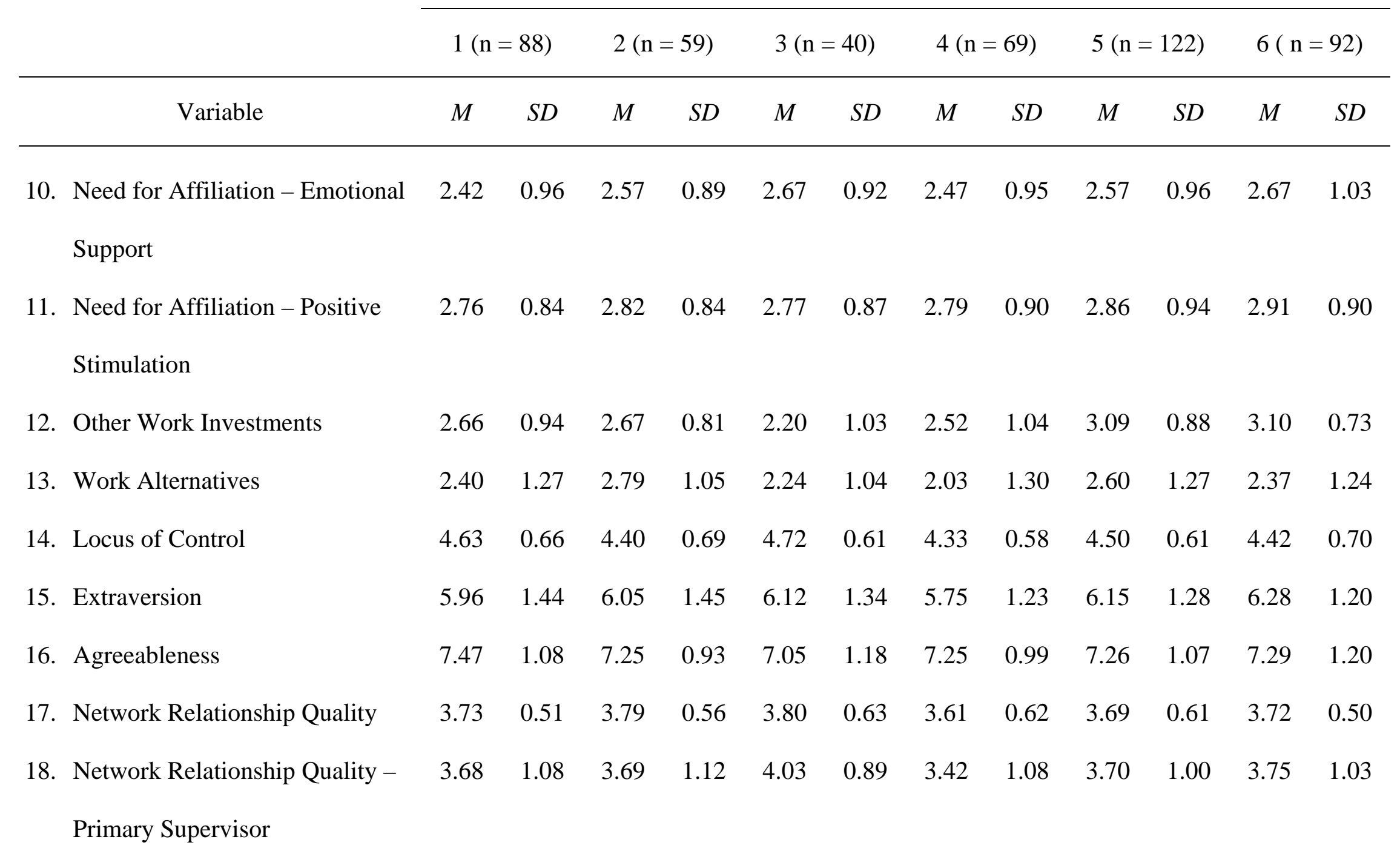


Organization

\begin{tabular}{|c|c|c|c|c|c|c|c|c|c|c|c|c|c|}
\hline & & \\
\hline \multirow{2}{*}{\multicolumn{2}{|c|}{ Variable }} & \multicolumn{2}{|c|}{$1(\mathrm{n}=88)$} & \multicolumn{2}{|c|}{$2(\mathrm{n}=59)$} & \multicolumn{2}{|c|}{$3(n=40)$} & \multicolumn{2}{|c|}{$4(n=69)$} & \multicolumn{2}{|c|}{$5(\mathrm{n}=122)$} & \multicolumn{2}{|c|}{$6(n=92)$} \\
\hline & & $M$ & $S D$ & $M$ & $S D$ & $M$ & $S D$ & $M$ & $S D$ & $M$ & $S D$ & $M$ & $S D$ \\
\hline \multirow[t]{2}{*}{19.} & Network Relationship Quality - & 3.66 & 0.58 & 3.69 & 0.63 & 3.71 & 0.69 & 3.53 & 0.68 & 3.63 & 0.64 & 3.70 & 0.60 \\
\hline & Coworkers & & & & & & & & & & & & \\
\hline \multirow[t]{2}{*}{20.} & Network Relationship Quality - & 3.81 & 0.55 & 3.76 & 0.72 & 3.76 & 0.43 & 3.64 & 0.87 & 3.66 & 0.69 & 3.62 & 0.58 \\
\hline & Subordinates & & & & & & & & & & & & \\
\hline \multirow[t]{2}{*}{21.} & Network Relationship Quality - & 4.04 & 0.55 & 4.16 & 0.67 & 4.04 & 0.74 & 4.01 & 0.64 & 4.08 & 0.61 & 4.06 & 0.55 \\
\hline & Friends & & & & & & & & & & & & \\
\hline \multirow[t]{2}{*}{22.} & Network Relationship Quality - & 3.65 & 0.64 & 3.85 & 0.53 & 3.64 & 0.61 & 4.03 & 0.72 & 3.66 & 0.73 & 3.71 & 0.65 \\
\hline & Work Associates & & & & & & & & & & & & \\
\hline 23. & Network Size & 12.20 & 5.85 & 11.68 & 4.83 & 12.03 & 4.11 & 11.61 & 5.37 & 13.76 & 6.05 & 13.58 & 5.06 \\
\hline 24. & Network Size - Coworkers & 5.99 & 2.00 & 6.22 & 1.89 & 7.00 & 1.68 & 6.09 & 1.95 & 6.78 & 1.63 & 6.54 & 1.97 \\
\hline 25. & Network Size - Subordinates & 4.29 & 2.63 & 4.82 & 2.08 & 6.25 & 2.19 & 5.16 & 2.48 & 5.78 & 2.31 & 6.26 & 2.45 \\
\hline 26. & Network Size - Friends & 4.01 & 2.09 & 3.82 & 2.15 & 4.35 & 2.35 & 4.18 & 2.22 & 4.75 & 2.32 & 4.52 & 2.60 \\
\hline 27. & Network Size - Work Associates & 3.80 & 2.11 & 3.95 & 2.37 & 3.94 & 2.43 & 4.26 & 2.67 & 4.50 & 2.35 & 3.69 & 2.07 \\
\hline
\end{tabular}


Organization

\begin{tabular}{|c|c|c|c|c|c|c|c|c|c|c|c|c|c|}
\hline & \multicolumn{2}{|c|}{$1(\mathrm{n}=88)$} & \multicolumn{2}{|c|}{$2(n=59)$} & \multicolumn{2}{|c|}{$3(n=40)$} & \multicolumn{2}{|c|}{$4(n=69)$} & \multicolumn{2}{|c|}{$5(\mathrm{n}=122)$} & \multicolumn{2}{|c|}{$6(n=92)$} \\
\hline \multicolumn{2}{|r|}{ Variable } & $M$ & $S D$ & $M$ & $S D$ & $M$ & $S D$ & $M$ & $S D$ & $M$ & $S D$ & $M$ & $S D$ \\
\hline 28. & Network Interaction & 4.00 & 0.80 & 4.14 & 0.54 & 4.36 & 0.77 & 4.38 & 0.51 & 4.11 & 0.50 & 4.20 & 0.57 \\
\hline \multirow[t]{2}{*}{29.} & Network Interaction - Primary & 4.50 & 0.79 & 4.31 & 0.92 & 4.75 & 0.71 & 4.75 & 0.50 & 4.54 & 0.71 & 4.51 & 0.92 \\
\hline & Supervisor & & & & & & & & & & & & \\
\hline 30. & Network Interaction - Coworkers & 3.79 & 1.19 & 4.17 & 0.67 & 4.51 & 0.47 & 4.56 & 0.53 & 4.26 & 0.55 & 4.37 & 0.59 \\
\hline \multirow[t]{2}{*}{31.} & Network Interaction - & 4.39 & 1.04 & 4.35 & 0.52 & 4.83 & 0.14 & 4.75 & 0.41 & 4.53 & 0.48 & 4.57 & 0.64 \\
\hline & Subordinates & & & & & & & & & & & & \\
\hline 32. & Network Interaction - Friends & 4.16 & 0.95 & 4.12 & 0.78 & 4.48 & 0.59 & 4.41 & 0.82 & 4.17 & 0.60 & 4.14 & 0.87 \\
\hline & Network Interaction - Work & 2.46 & 1.05 & 1.99 & 0.69 & 2.80 & 1.09 & 2.72 & 1.02 & 2.95 & 1.16 & 3.03 & 1.12 \\
\hline & Associates & & & & & & & & & & & & \\
\hline 34. & Relative Network Status & 2.08 & 0.36 & 2.06 & 0.34 & 2.00 & 0.39 & 2.03 & 0.51 & 1.98 & 0.35 & 1.98 & 0.39 \\
\hline 35. & Relative Network Status - & 2.15 & 0.37 & 2.01 & 0.37 & 2.07 & 0.41 & 2.02 & 0.54 & 2.02 & 0.38 & 2.03 & 0.42 \\
\hline
\end{tabular}

Coworkers 


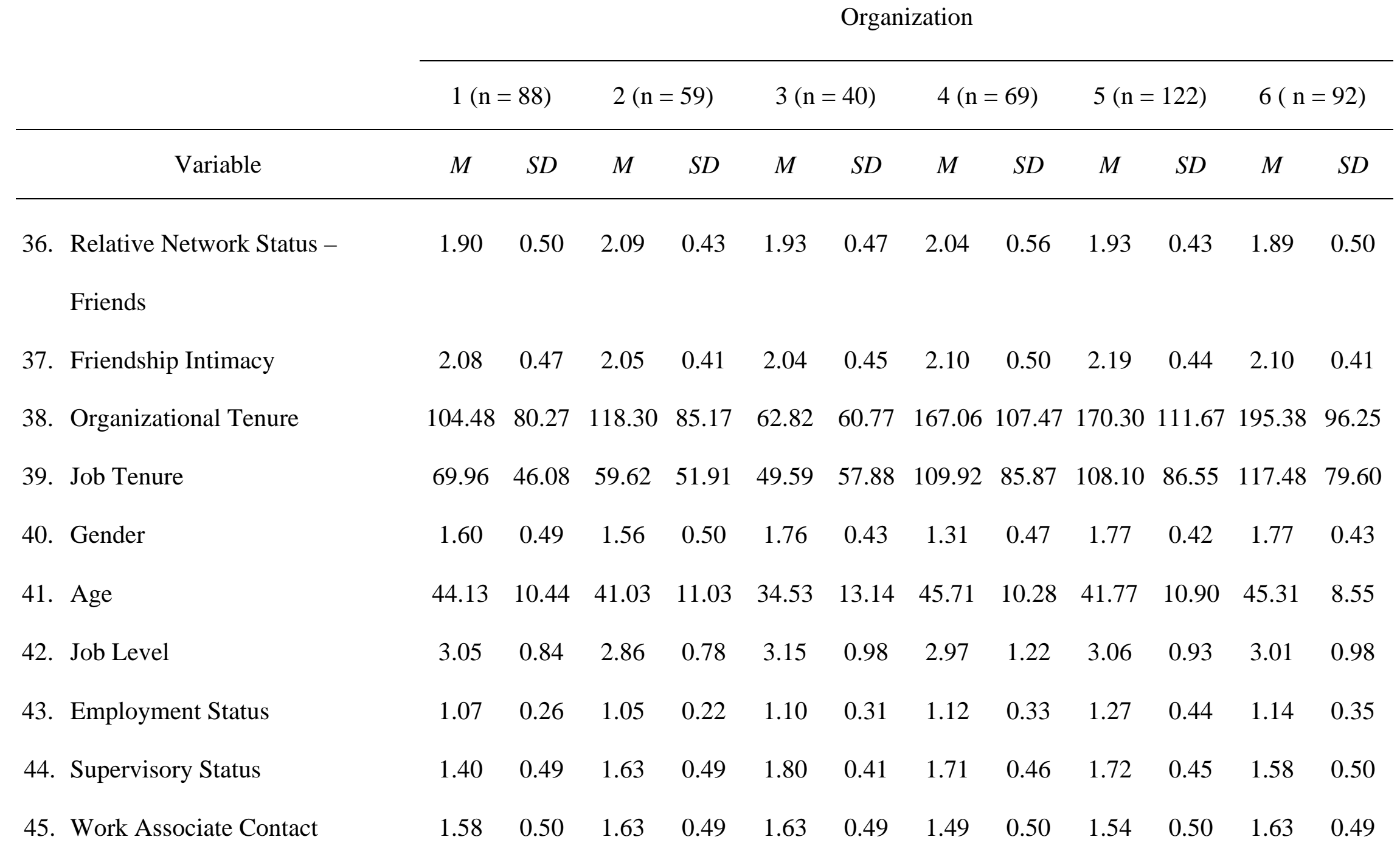


Table 4

Testing Hypothesis 1: Work Relationships (i.e., Network Size, Relative Network Status, Network Relationship Quality, and Network Interaction) Will Predict Incremental Variance in Personal Sacrifice after Accounting for Job Satisfaction, Job Alternatives, and Other Work Investments

$$
\text { Standardized Cumulative Adjusted } \quad R^{2} \quad \text { F }
$$

\begin{tabular}{|c|c|c|c|c|c|c|c|c|}
\hline Model & Variable & Beta Weight & $\mathrm{R}^{2}$ & $\mathrm{R}^{2}$ & Change & $d f 1$ & $d f 2$ & Change \\
\hline \multirow[t]{3}{*}{1} & Other Work & $.27 * *$ & .06 & .05 & .06 & 3 & 463 & $8.95 * *$ \\
\hline & Investments & & & & & & & \\
\hline & Work & $-.13^{*}$ & & & & & & \\
\hline
\end{tabular}

Alternatives

Job $\quad .05$

Satisfaction

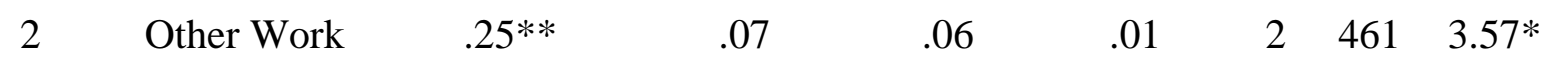

Investments

Work $\quad-.12 *$

Alternatives

Job $\quad .05$

Satisfaction

Network Size $\quad .10 *$

Relative $\quad-.06$

Network Status

$* p<.05 \quad * * p<.01$ 
Table 5

Testing Hypothesis 2: Larger Social Networks, Networks Comprised of Relatively Higher Status Individuals, Networks Comprised of Higher Quality Relationships, and More Frequent Interaction with Network Contacts Will Predict Incremental Variance in Personal Sacrifice after Accounting for Other Work Investments

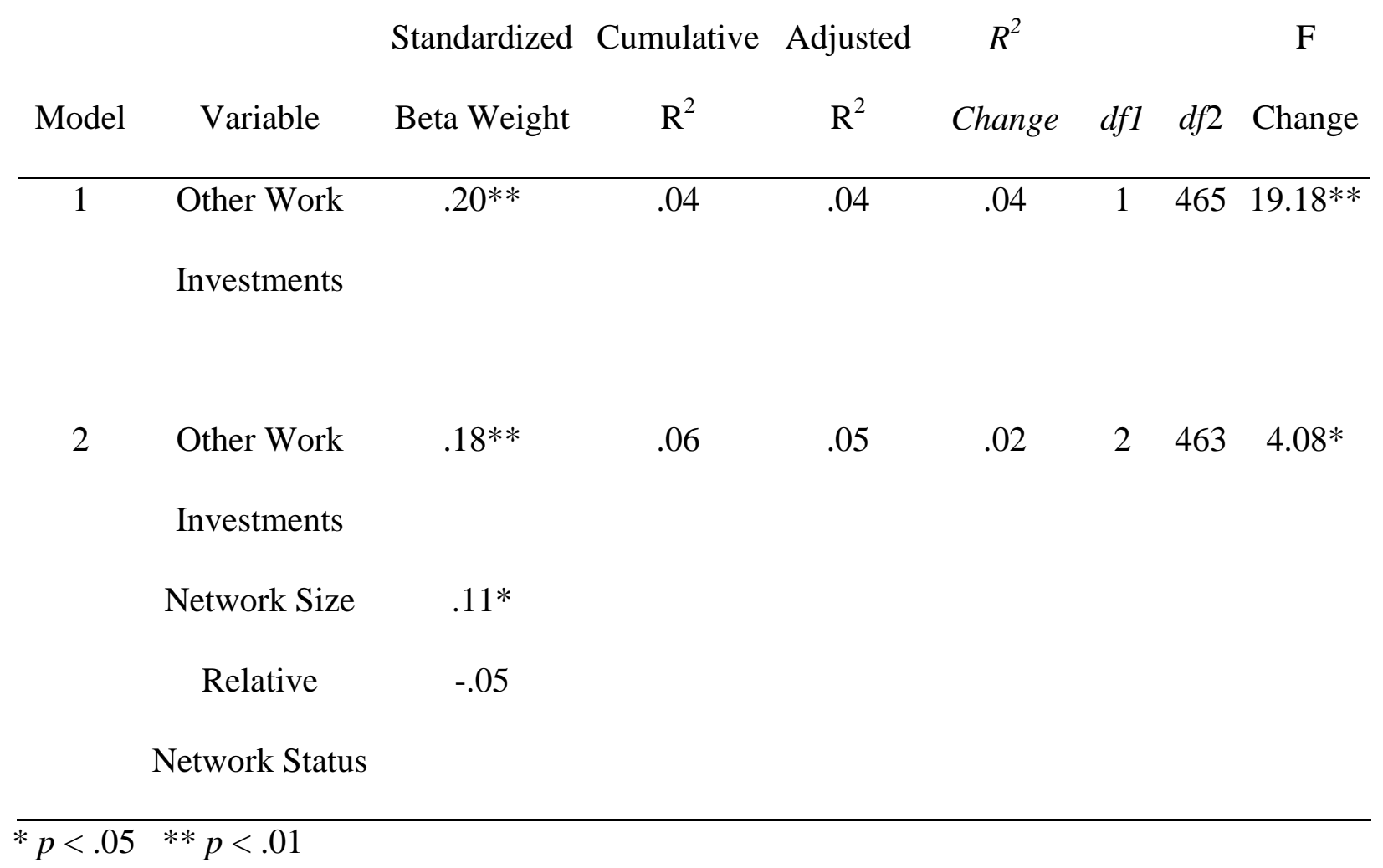


Table 6

Testing Hypothesis 3: Larger Social Networks, Networks Comprised of Relatively Higher Status Individuals, Networks Comprised of Higher Quality Relationships, and More Frequent Interaction with Network Contacts Will Predict Incremental Variance in Intentions to Quit after Accounting for Personal Sacrifice

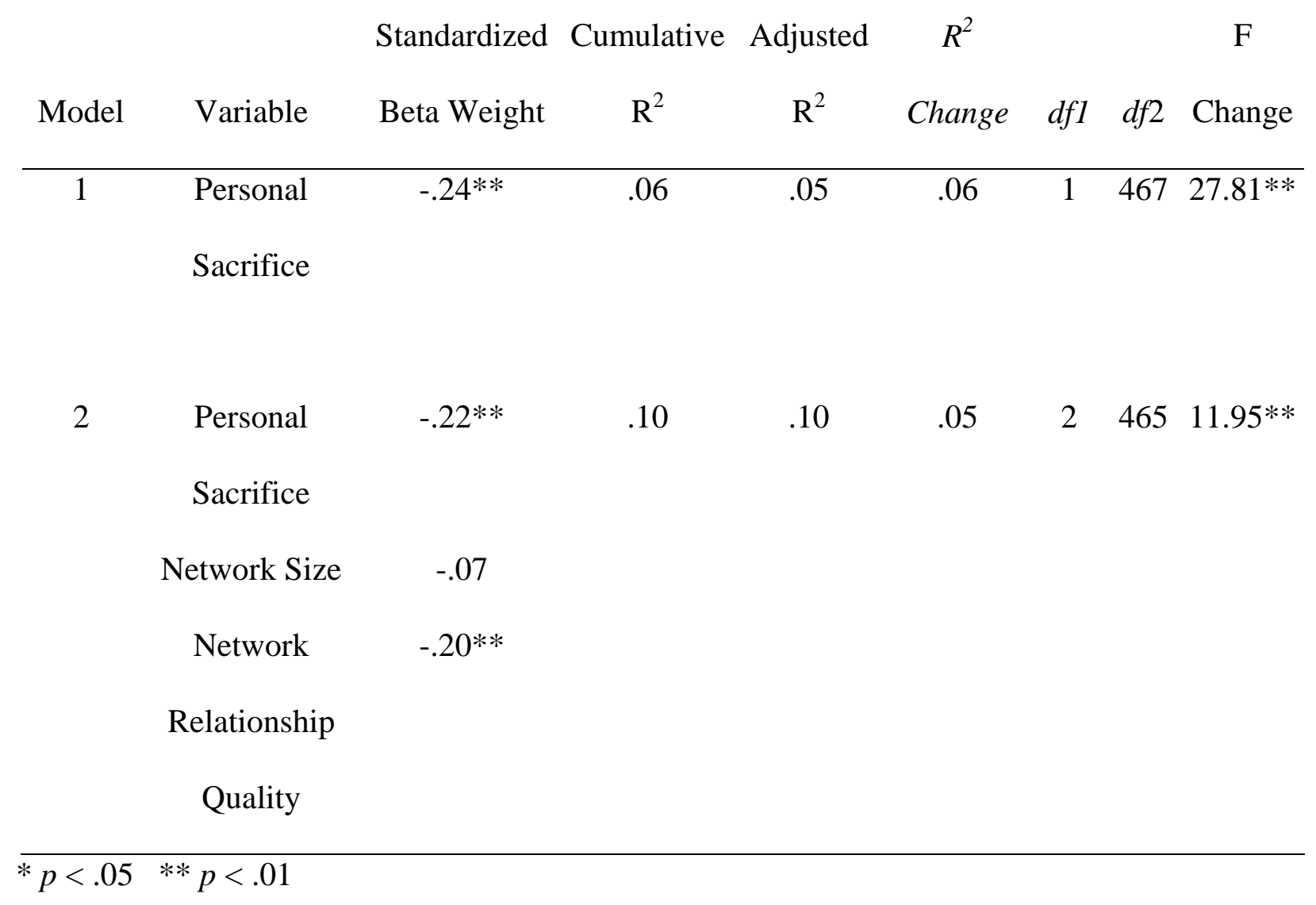


Table 7

Testing Hypothesis 4: Network Size Will Positively Predict the Size of the Personal Sacrifice Associated with Leaving One’s Job

\begin{tabular}{|c|c|c|c|c|c|c|}
\hline & Standardized & & djust & & & \\
\hline Variable & Beta Weight & $\mathrm{R}^{2}$ & $\mathrm{R}^{2}$ & $d f 1$ & $d f 2$ & $\mathrm{~F}$ \\
\hline Network Size & $.13 * *$ & .02 & .02 & 1 & 468 & $8.36 * *$ \\
\hline
\end{tabular}


Table 8

Testing Hypothesis 5: Relative Network Status Will Positively Predict the Size of the Personal Sacrifice Associated with Leaving One's Job

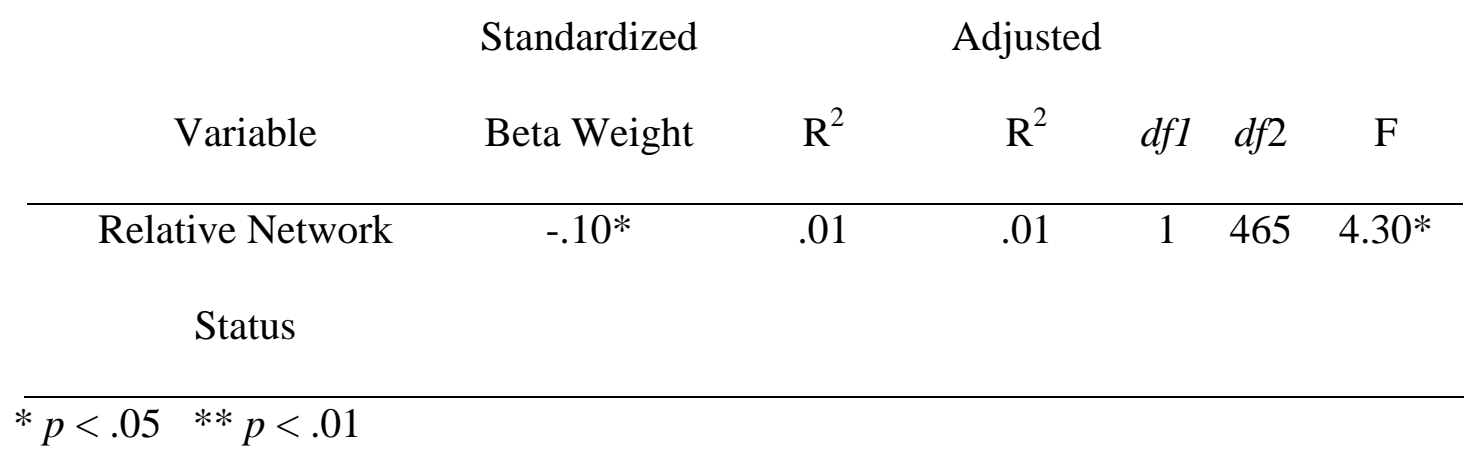


Table 9

Testing Hypothesis 6: Network Interaction Will Positively Predict the Size of the Personal Sacrifice Associated with Leaving One's Job

\begin{tabular}{ccccccc} 
& Standardized & \multicolumn{5}{c}{ Adjusted } \\
Variable & Beta Weight & $\mathrm{R}^{2}$ & $\mathrm{R}^{2}$ & $d f 1$ & $d f 2$ & $\mathrm{~F}$ \\
& & & & & & \\
\hline Network Interaction & -.05 & .00 & .00 & 1 & 467 & 1.14 \\
& & & & & & \\
\hline$p<.05 * * p<.01$ & & & & & &
\end{tabular}


Table 10

Testing Hypothesis 7: Network Relationship Quality Will Positively Predict the Size of the Personal Sacrifice Associated with Leaving One’s Job

\begin{tabular}{|c|c|c|c|c|c|c|}
\hline & Standardized & & djust & & & \\
\hline Variable & Beta Weight & $\mathrm{R}^{2}$ & $\mathrm{R}^{2}$ & $d f 1$ & $d f 2$ & $\mathrm{~F}$ \\
\hline Network Relationship & .04 & .00 & .00 & 1 & 467 & .79 \\
\hline Quality & & & & & & \\
\hline
\end{tabular}


Table 11

Testing Hypothesis 8: Need for Affiliation Will Moderate the Relationship between Network Size and Personal Sacrifice

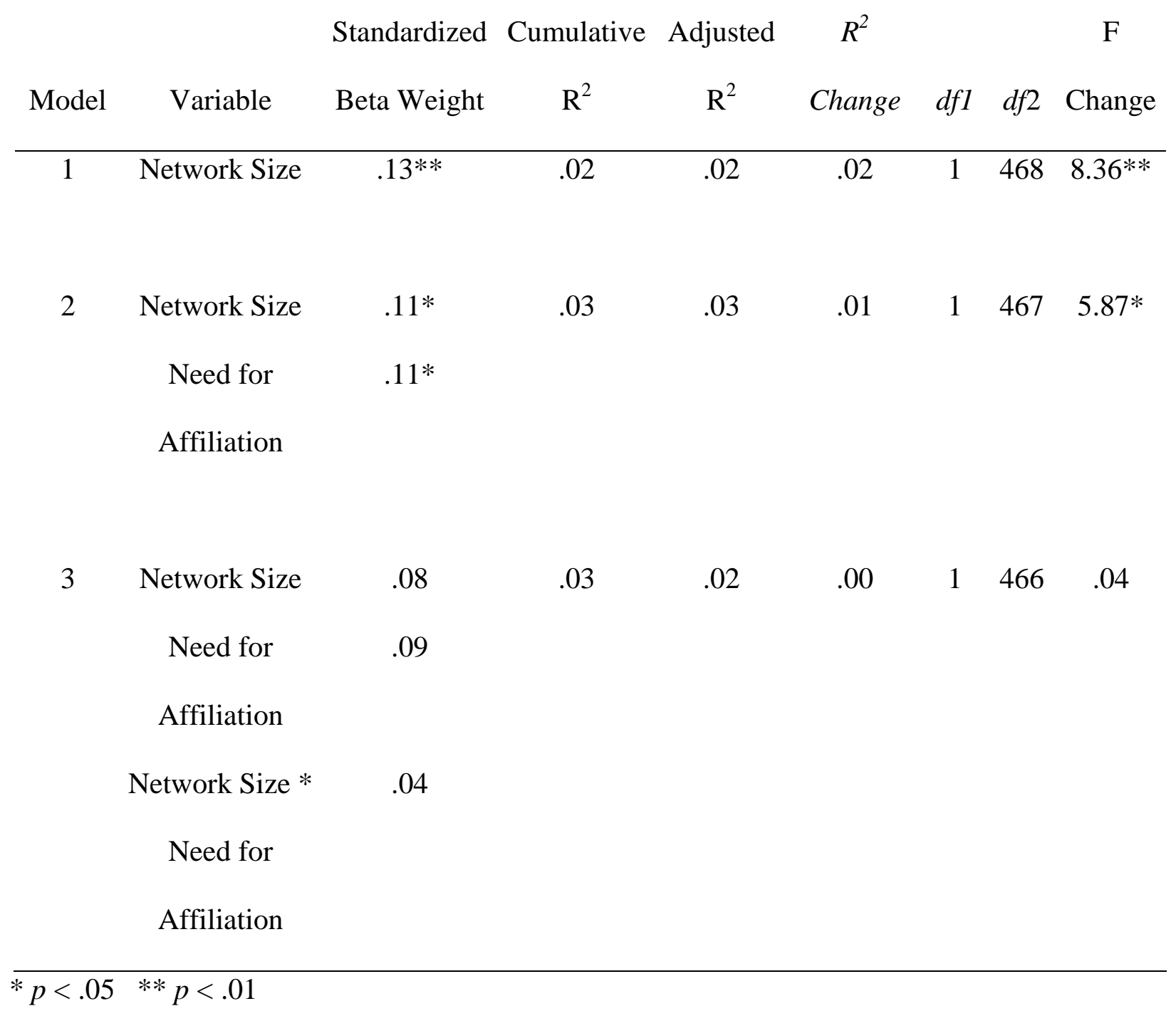


Table 12

Testing Hypothesis 8: Need for Affiliation Will Moderate the Relationship between Relative Network Status and Personal Sacrifice

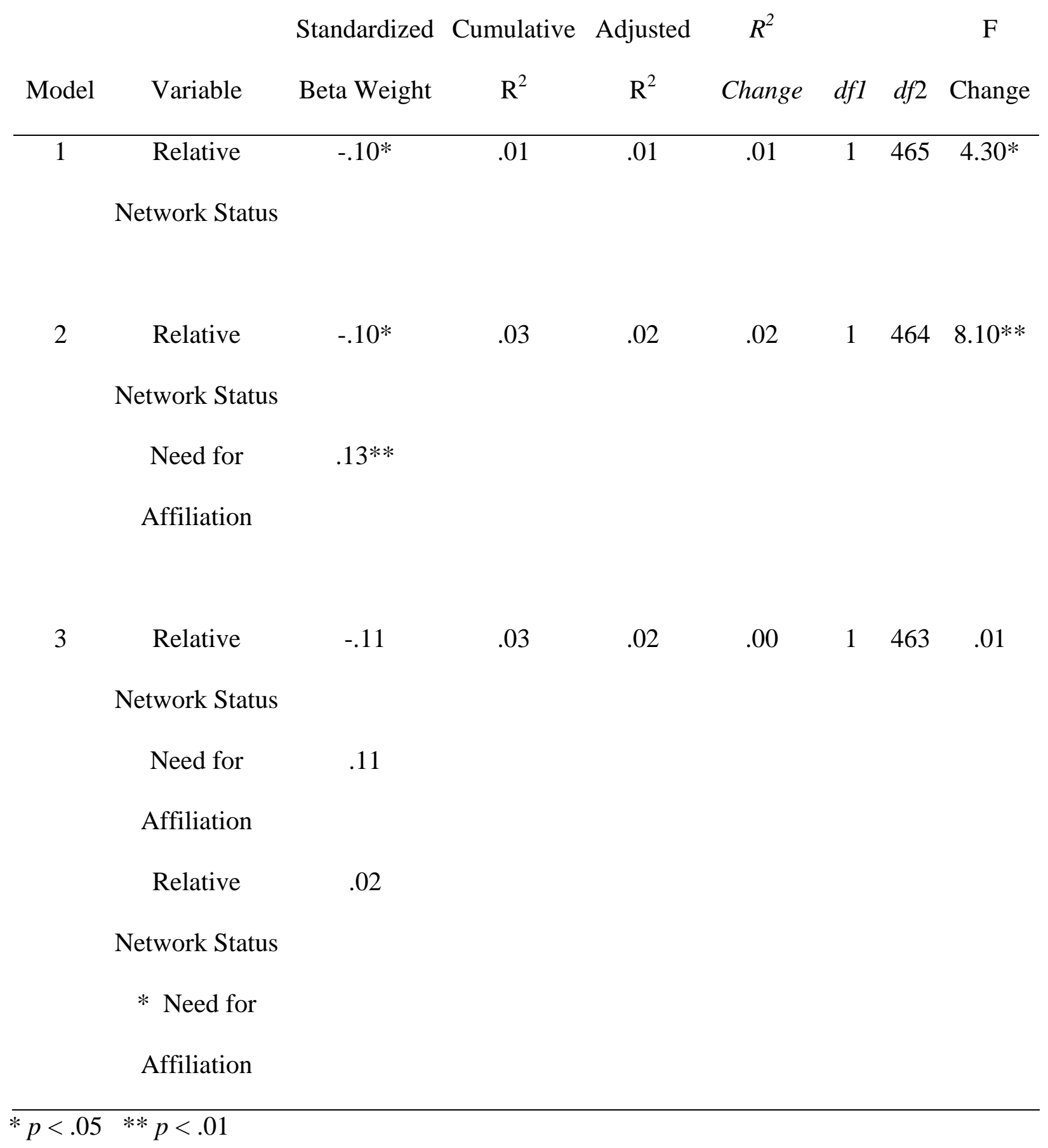


Table 13

Testing Hypothesis 9: Workplace Friendship Opportunity Will Moderate the Relationship between Network Size and Personal Sacrifice

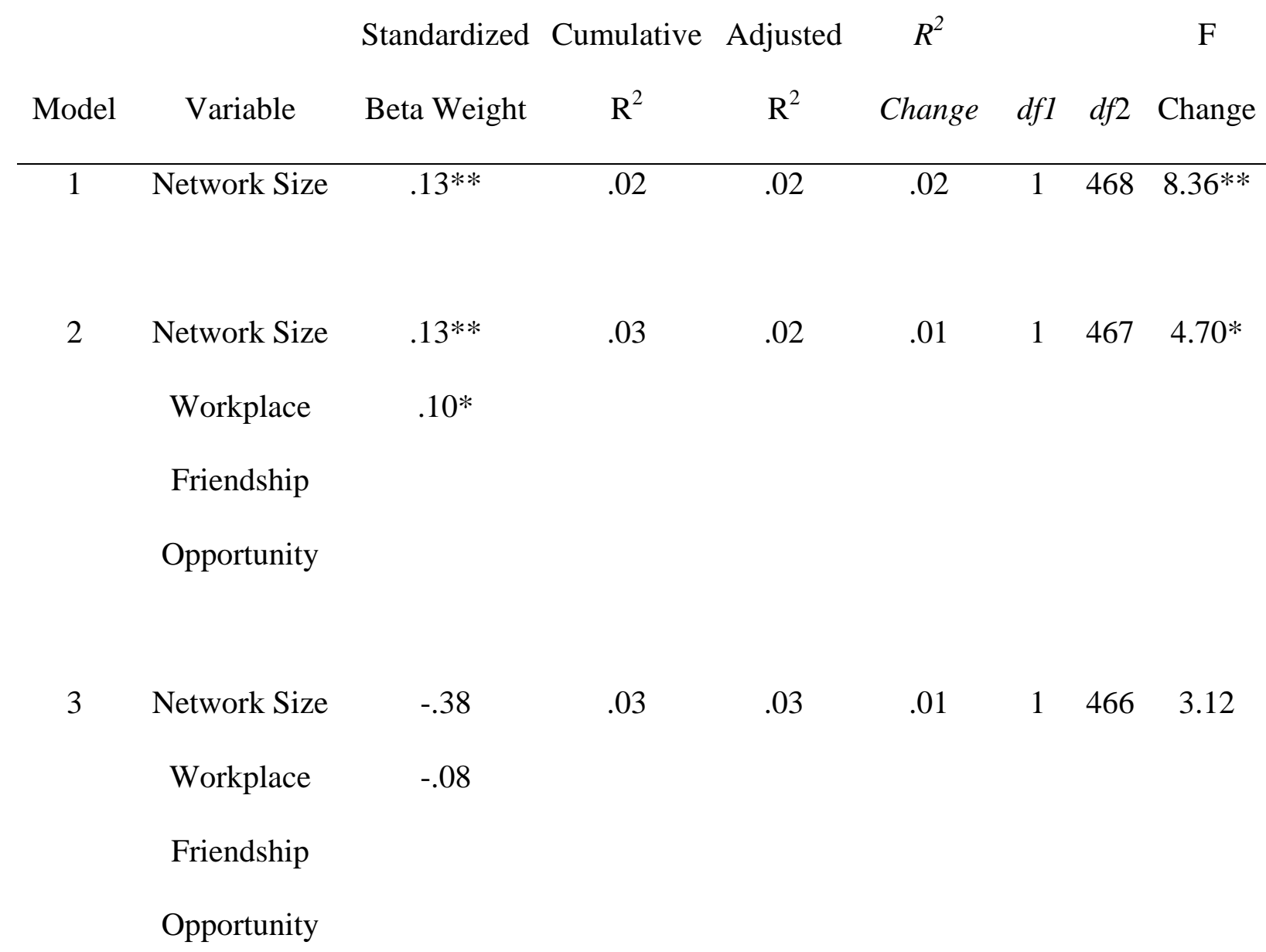

Network Size * $\quad .56$

Workplace

Friendship

Opportunity

$* p<.05 \quad * * p<.01$ 
Table 14

Testing Hypothesis 9: Workplace Friendship Opportunity Will Moderate the Relationship between Relative Network Status and Personal Sacrifice

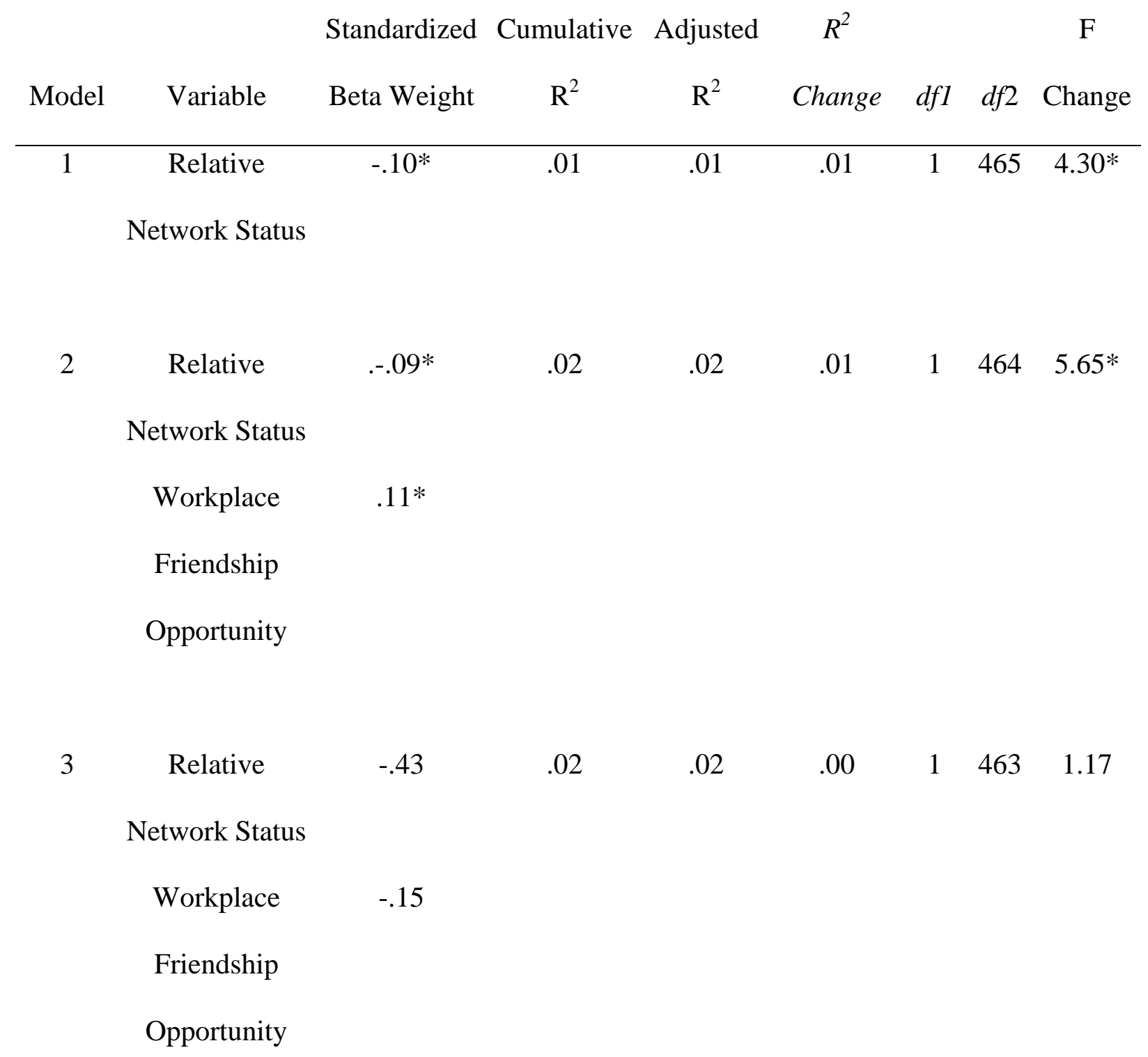


Relative .42

Network Status

* Workplace

Friendship

Opportunity

$* p<.05 \quad * * p<.01$ 


\section{Table 15}

Testing Hypothesis 10: Extraversion and Agreeableness Will Positively Predict Network Size, Relative Network Status, Network Interaction, and Network Relationship Quality

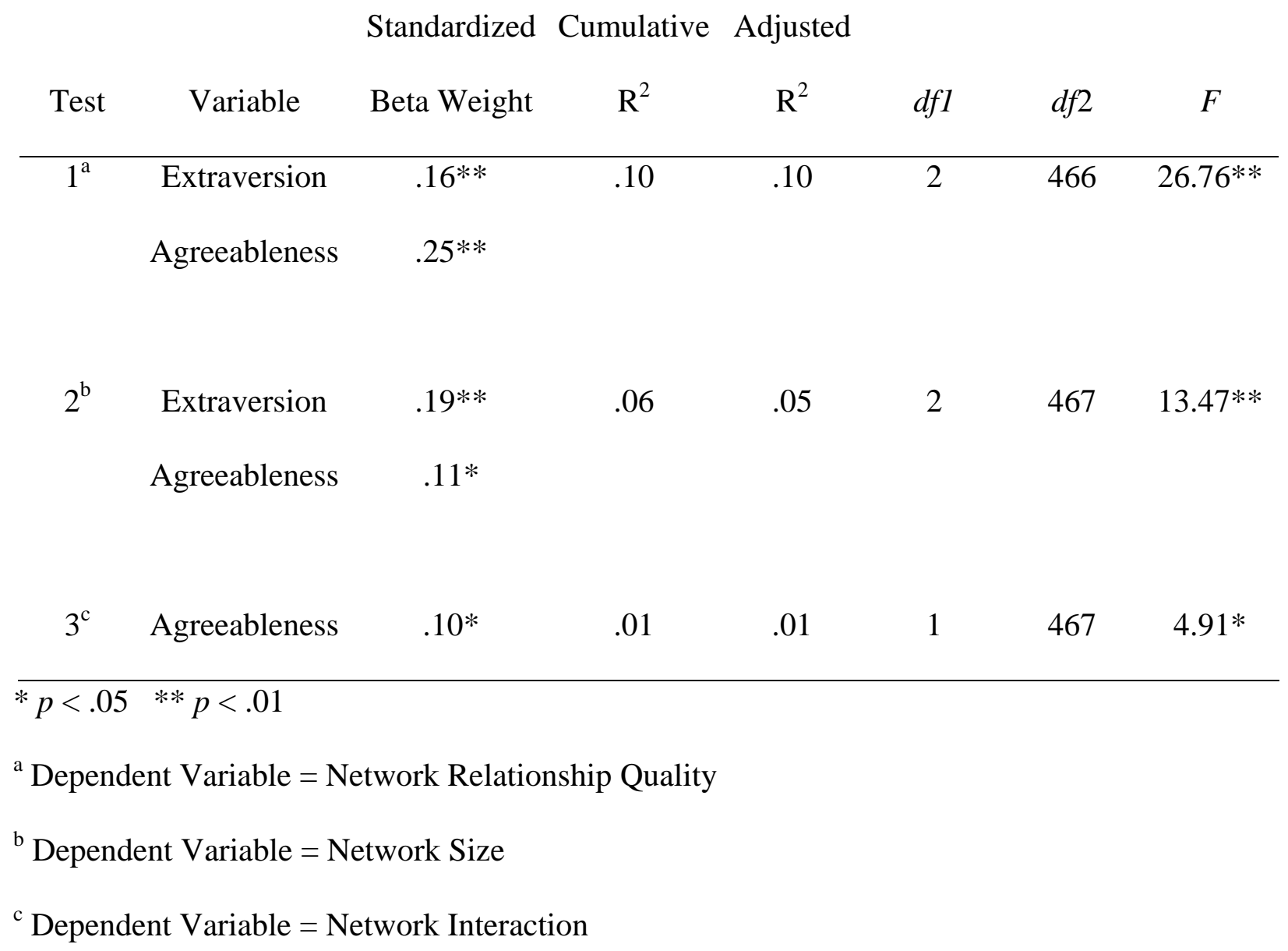


Table 16

Testing Hypothesis 11: An Internal Locus of Control Will Positively Predict Network Size, Relative Network Status, Network Interaction, and Network Relationship Quality

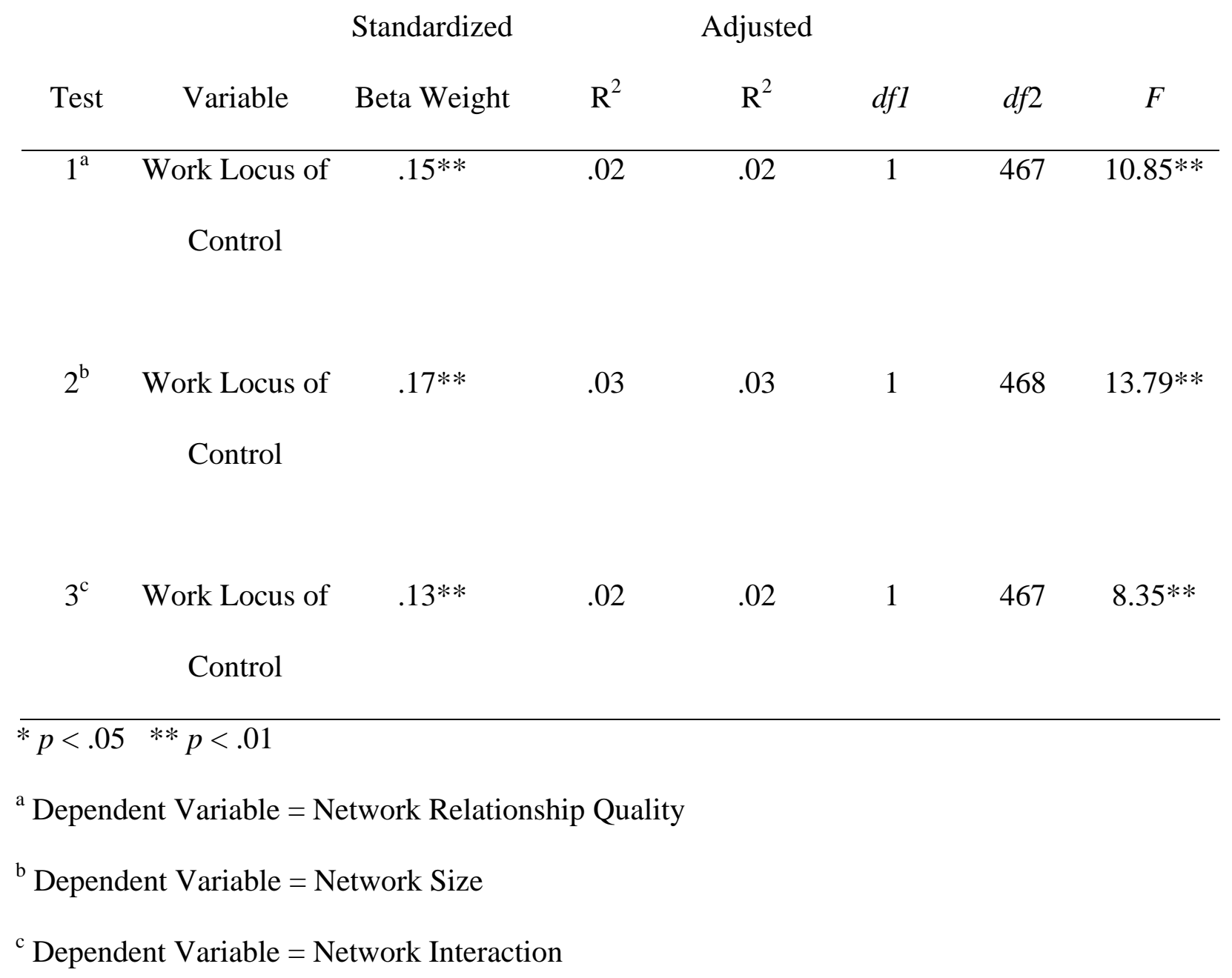


Table 17

Testing Hypothesis 12: The Relationship between Locus of Control and Personal Sacrifice Will Be Mediated by Network Size, Relative Network Status, Network Interaction, and Network Relationship Quality

Standardized Cumulative Adjusted

\begin{tabular}{|c|c|c|c|c|c|c|c|}
\hline Test & Variable & Beta Weight & $\mathrm{R}^{2}$ & $\mathrm{R}^{2}$ & $d f 1$ & $d f 2$ & $F$ \\
\hline $1^{\mathrm{a}}$ & $\begin{array}{c}\text { Work Locus of } \\
\text { Control }\end{array}$ & $.16^{* *}$ & .03 & .02 & 1 & 467 & $12.61^{* *}$ \\
\hline $2^{b}$ & $\begin{array}{c}\text { Work Locus of } \\
\text { Control }\end{array}$ & $-.11 *$ & .01 & .01 & 1 & 468 & $5.23 *$ \\
\hline $3^{c}$ & $\begin{array}{c}\text { Work Locus of } \\
\text { Control }\end{array}$ & $-.12 * *$ & .03 & .03 & 2 & 466 & $6.97^{* *}$ \\
\hline
\end{tabular}

Network Size $\quad .14^{* *}$

$* p<.05 \quad * * p<.01$

${ }^{\mathrm{a}}$ Dependent Variable $=$ Network Size

${ }^{\mathrm{b}}$ Dependent Variable $=$ Personal Sacrifice

${ }^{\mathrm{c}}$ Dependent Variable $=$ Personal Sacrifice 
Table 18

Testing Hypothesis 13: Job Satisfaction Will Predict the Size of the Personal Sacrifice Associated with Leaving One's Job

\begin{tabular}{|c|c|c|c|c|c|c|}
\hline & Standardized & & djuste & & & \\
\hline Variable & Beta Weight & $\mathrm{R}^{2}$ & $\mathrm{R}^{2}$ & $d f 1$ & $d f 2$ & $\mathrm{~F}$ \\
\hline Job Satisfaction & .07 & .01 & .00 & 1 & 468 & 2.55 \\
\hline
\end{tabular}


Table 19

Summary of Regression Tests Sorted by Results

\begin{tabular}{|c|c|c|}
\hline Hypothesis & Result & Description of Findings \\
\hline 4 & Supported & Network size predicted personal sacrifice. \\
\hline \multirow[t]{3}{*}{1} & Partially & Investment model applied to work relationships partially supported. Network size explained \\
\hline & Supported & additional variance in personal sacrifice beyond job satisfaction, job alternatives, and other work \\
\hline & & investments. \\
\hline \multirow[t]{2}{*}{2} & Partially & Network size explained additional variance in personal sacrifice beyond other work investments. \\
\hline & Supported & \\
\hline \multirow[t]{2}{*}{3} & Partially & Network relationship quality explained additional variance in intentions to quit beyond personal \\
\hline & Supported & sacrifice. \\
\hline \multirow[t]{2}{*}{5} & Partially & Relative network status predicted personal sacrifice, although negatively. \\
\hline & Supported & \\
\hline \multirow[t]{2}{*}{10} & Partially & Extraversion positively predicted network relationship quality and network size. Agreeableness \\
\hline & Supported & positively predicted network relationship quality, network size and network interaction. \\
\hline \multirow[t]{2}{*}{11} & Partially & Work locus of control positively predicted network relationship quality, network size, and network \\
\hline & Supported & interaction. \\
\hline
\end{tabular}


Hypothesis Result $\quad$ Description of Findings

$6 \quad$ Not Supported Network interaction did not predict personal sacrifice.

$7 \quad$ Not Supported Network relationship quality did not predict personal sacrifice.

8 Not Supported Need for affiliation did not moderate the relationship between work relationships (i.e., network size, relative network status, network interaction, and network relationship quality) and personal sacrifice.

$9 \quad$ Not Supported Workplace friendship opportunity did not moderate the relationship between work relationships (i.e., network size, relative network status, network interaction, and network relationship quality) and personal sacrifice.

12 Not Supported The relationship between work locus of control and personal sacrifice was not mediated by work relationships (i.e., network size, relative network status, network interaction, and network relationship quality).

13 Not Supported Job satisfaction did not predict personal sacrifice. 